\title{
SUSPECT SYMBOLS: THE LITERARY ARGUMENT FOR HEIGHTENED SCRUTINY FOR GAYS
}

\author{
Kenji Yoshino* \\ INTRODUCTION
}

This Article can be read as a response to a question a federal appellate judge asked me. During a clerkship interview, the judge inquired about a course on my transcript subtitled "Queer Theory." I told him it was a course on legal, political, and sociological theories of sexual orientation and mapped some of its themes. He listened attentively, then stated: "Actually, what I wanted to know was what the word 'queer' means." Quick to rationalize authority, I assumed he knew what the word meant, and was attempting to gauge the subtlety of my understanding of it. So I responded: "My understanding is that it's a term once used in a derogatory way towards homosexuals that has been co-opted by the gayrights movement, like the pink triangle." I I was about to continue, when he interrupted: "What's the pink triangle?" A beat. I replied: "The pink triangle was used by the Nazis during the Holocaust to designate homosexuals." The judge said: "I didn't know that."

I knew that the judge recently had heard a controversial case considering whether gays should be accorded heightened scrutiny under the Equal Protection Clause of the Fourteenth Amendment, and therefore assumed he had a certain modicum of cultural literacy about gays. ${ }^{2}$ My

* Law Clerk to Judge Guido Calabresi, United States Court of Appeals for the Second Circuit. J.D. Yale Law School, 1996. A previous version of this Article was part of a body of work that was awarded the Theron Rockwell Field Prize by Yale University. I am indebted to many people for their help throughout this project, including Bruce Ackerman, Akhil Reed Amar, Peter Brooks, Guido Calabresi, Thomas B. Colby, Laura A. Dickinson, Glenn C. Edwards, William N. Eskridge, Jr., Owen M. Fiss, Ryan Goodman, Rachel Harmon, Melissa R. Hart, Katharine A. Huffman, Neal Katyal, Harold Hongiu Koh, Bob Newman, Alison Peck, Richard A. Primus, Chris Sclafani Rhee, Jeannie Sclafani Rhee, William B. Rubenstein, Shilpa S. Satoskar, Reva B. Siegel, and Tobias B. Wolff. Nestor M. Davidson provided outstanding editorial assistance. All errors are mine.

1. Throughout this Article, I employ the words "gay" and "homosexual" to designate those persons who have a significant sexual attachment to those of the same biological sex. I do this for the sake of brevity, and intend the terms to include women as well as men. Janet Halley's disclaimer is appropriate here:

In this Article I use the terms "homosexuality" and "homosexual"-and more tendentiously, the terms "heterosexuality" and "heterosexual"-without any implication that they accurately describe any persons living or dead. As I try to use them here, these terms describe rhetorical categories that have real, material importance notwithstanding their failure to provide adequate descriptions of any one of us.

Janet E. Halley, Reasoning About Sodomy: Act and Identity in and After Bowers $v$. Hardwick, 79 Va. L. Rev. 1721, 1723 (1993).

2. This Article implicates three constitutional arguments for gay rights, but focuses on one. The first derives from the Due Process Clause of the Fourteenth Amendment. As part of "substantive due process," courts have considered a variety of privacy rights relating 
immediate reaction to his question about the word "queer" was to interpret it as a test given by a teacher. When he asked about the pink triangle, I could no longer sustain the illusion. Like the thirteenth chime of the clock that calls all that preceded it mto question, the query forced me to rethink the turns the conversation had taken.

I would not blame the reader who thought I was naive to be shocked at this interchange. Judges constantly decide matters in which they are inexpert, regulating identities, as this judge did in the gay Equal Protection case, without knowing the basics of those identities. ${ }^{3}$ My shock was

to: childrearing or education, see Pierce v. Society of Sisters, 268 U.S. 510 (1925) (striking down statute requiring children to attend public schools); Meyer v. Nebraska, 262 U.S. 390 (1923) (striking down statute prohibiting the teaching of foreign langnages before eighth grade); marriage, see Loving v. Virginia, 388 U.S. 1 (1967) (striking down miscegenation statute); contraception, see Eisenstadt v. Baird, 405 U.S. 438 (1972) (invalidating regulation that made contraceptives less available to unmarried than to married couples); Griswold v. Connecticut, 381 U.S. 479 (1965) (striking down law criminalizing use of contraceptives by married persons); and abortion, see Roe v. Wade, 410 U.S. 113 (1973) (striking down statute prohibiting abortion). In 1986, the Supreme Court declined to extend this line of cases to cover the right to engage in homosexual sodomy in Bowers $v$. Hardwick, 478 U.S. 186 (1986). Both the pre- and post-Bowers legal literature on the connection between privacy and homosexuality are voluminous. See, for example, the sources cited in Kendall Thomas, Beyond the Privacy Principle, 92 Colum. L. Rev. 1431, 1436 n.8 (pre-Bowers), 1434 n.7 (post-Bowers) (1992).

Since Bowers, gay-rights litigation has shifted toward the Equal Protection Clause of the Fourteenth Amendment and the Equal Protection component of the Fifth Amendment. The second and third arguments derive from Equal Protection analysis. Under the "suspect classification" strand of Equal Protection jurisprudence, courts recognize different groups within society as meriting particular judicial protection from government-based discrimination. Groups asking for protection are separated into three categories: those requiring "strict" scrutiny (which requires that the government classification meet the exceedingly difficult standard of being "necessary to promote a compelling governmental interest," Shapiro v. Thompson, 394 U.S. 618, 634 (1969)), those requiring "intermediate" scrutiny (which requires that the government classification "serve important government objectives ... substantially related to . . . those objectives," Craig v. Boren, 429 U.S. 190, 197 (1976)), and those requiring only "rational review" (which requires that the government classification be "rationally related to a legitimate government interest," United States Dep't of Agric. v. Moreno, 413 U.S. 528, 533 (1973)). Classifications based on homosexuality have thus far been analyzed under the "rational review" standard.

The second argument proposes that discrimination against gays constitutes discrimination on the basis of sex and asks courts to apply the intermediate level of scrutiny accorded sex-based classifications to classifications based on sexual orientation. See Andrew Koppelman, Why Discrimination Against Lesbians and Gay Men Is Sex Discrimination, 69 N.Y.U. L. Rev. 197 (1994) (argning for holding discrimination against gays to be sex discrimination). While this theory recently was adopted by the Hawaii State Supreme Court in the groundbreaking case of Baehr v. Lewin, 852 P.2d 44 (Haw. 1993), it has not been the primary battlefield of gay Equal Protection doctrine.

The third argument seeks to garner intermediate scrutiny for gays as gays. This Article focuses on that argument Unless I indicate otherwise, I am referring to this argnment when I allude to the "Equal Protection argnment for gays" or the "heightened scrutiny argument for gays."

3. "Identity" is hard to define. One might question whether anyone knows the basics of gay "identity" given the wide diversity of life experiences even among those who self- 
fueled, however, less by the judge's ignorance about gays than by the thought that his ignorance of the pink triangle had pointed relevance to the doctrinal analysis in the case he had just decided. One of the three prongs of the heightened scrutiny inquiry mandated by the Equal Protection Clause asks whether the group in question has suffered a history of discrimination. It struck me that the pink triangle responded directly to this inquiry, as it symbolizes the persecution gays suffered during the Holocaust, much in the way the yellow star stands as an emblem of the persecution suffered by Jews. More subtly, the pink triangle speaks to the invisibility of gay history by rendering evident its invisible Holocaustal moment much in the way that the symbol itself, during that moment, rendered evident the invisible homosexual. I did not think it fanciful to believe that knowledge of the pink triangle, laden as it is with such associations, might have changed the judge's doctrinal analysis.

This made me wonder about how the application of the other two prongs of the Equal Protection Clause to gays might be enriched by other gay symbols. ${ }^{4}$ Courts interpret the Equal Protection Clause to require a three-prong inquiry to determine whether a group deserves heightened scrutiny. That inquiry asks (1) whether the group has suffered a history of discrimination, (2) whether the group is politically powerless, and (3) whether the group is inarked by an immutable characteristic. ${ }^{5}$ Just as the

identify as gay, a division that has become more evident as the political solidarity of gay liberation in the 1970s has fragmented along gender, race, and other lines. See Steven Seidman, Identity and Politics in a "Postmodern" Gay Culture: Some Historical and Conceptual Notes, in Fear of a Queer Planet: Queer Politics and Social Theory 105, 117-27 (Michael Warner ed., 1993). When I use the words "gay identity" I mean nothing more than the shared experience of having a sexual attachment to persons of the same sex and the oppression experienced because of that attachment. Similarly, my use of the word "movement" should not imply that this movement is unified other than in its resistance to this oppression.

4. As used here, a symbol is a cultural sign that represents a referent that is not present. It can be completely arbitrary relative to its referent (such as the operation indicators of algebra or the pink triangle), have a cultural bond of signification (such as the fifty stars of the American flag or the closet), or have a so-called "natural" bond of significauion (such as the dream symbols of psychoanalysis or the body). See Hanna $F$. Pitkin, The Concept of Representation 95-96 (1967).

5. This test is based on the one outlined by the Supreme Court in Bowen v. Gilliard, 483 U.S. 587, 602 (1987) (citing Lyng v. Castillo, 477 U.S. 635, 638 (1986)). Not all courts follow this (or any other) clear-cut test when they consider whether to grant a group heightened scrutiny. To the contrary, courts often employ other forms of this test or engage in a kind of gestalt reading without explicitly adverting to a test. Lower courts in the gay context, however, have been remarkably (although not completely) consistent in following this three-prong test. See Watkins v. United States Army, 847 F.2d 1329 (9th Cir. 1988) (according gays heightened scrutiny), vacated and aff'd on other grounds, 875 F.2d 699 (9th Cir. 1989) (en banc); Baker v. Wade, 769 F.2d 289 (5th Cir. 1985) (denying gays heightened scrutiny); Rich v. Secretary of the Army, 735 F.2d 1220 (10th Cir. 1984) (same); Equality Found. v. City of Cincinnati, 860 F. Supp. 417 (S.D. Ohio 1994) (according gays heightened scrutiny), rev'd, 54 F.3d 261 (6th Cir. 1995), vacated and remanded, 116 S. Ct. 2519 (1996); Steffan v. Cheney, 780 F. Supp. 1 (D.D.C. 1991) (same), rev'd on other grounds sub nom. Steffan v. Aspin, 8 F.3d 57 (D.C. Cir. 1993) (holding 
first prong resonates with the pink triangle, the other two prongs resonate with symbols common in the gay-rights movement. The politicalpowerlessness prong implicates the symbol of the closet insofar as the closet captures the invisibility and isolation that hinder gays in their political mobilization. The immutability prong implicates the symbol of the body insofar as the body traditionally has been a way of conceiving of both immutability and sexual deviance. In all three instances, judicial discussions of these prongs as applied to gays have not adverted to these symbols.

In the near future, the United States Supreme Court is likely to consider the argument that gays should receive heightened scrutiny. That possibility assumes an added urgency because the argument ultimately has been rejected by every circuit to confront the issue. 6 The main purpose of this Article is to strengthen the argument for heightened scrutiny for gays by examining how these symbols-triangle, closet, body-provide a "thicker" response to the Equal Protection inquiry than has been attempted under the conventional doctrinal framework. ${ }^{7}$

This kind of unconventional analysis necessarily raises the antecedent question of what counts as an argument in the law. In Part I, I analyze the resistance that occurs when "literary" arguments are made in the law. After diagnosing the sources of that resistance, I contend that the combination of the Equal Protection Clause and symbols should mitigate it. Parts II through IV then consider each combination of prong and symbol to show the work the symbols can do. When we consider whether

regulation did not survive rational review), rev'd sub nom. Steffan v. Perry, 41 F.3d 677 (D.C. Cir. 1994) (en banc); Jantz v. Muci, 759 F. Supp. 1543 (D. Kan. 1991) (according gays heightened scrutiny), rev'd, 976 F.2d 623 (10th Cir. 1992); High Tech Gays v. Defense Indus. Sec. Clearance Office, 668 F. Supp. 1361 (N.D. Cal. 1987) (same), rev'd, 895 F.2d 563 (9th Cir. 1990). Given this critical mass of precedent, a court considering heightened scrutiny for gays likely will use some version of the three-prong test.

Courts have treated each prong as independent and necessary, with the failure to satisfy any prong foreclosing the possibility of heightened scrutiny. For the most part, I capitulate to this framework even where I disagree with it to keep my answer as consistent as possible with the normative assumptions of the courts. Often, however, there are implicit admissions by a court that each prong is neither independent nor required. The three prongs often bleed into each other-for example, a finding of historical discrimination may "trickle over" into a finding of political powerlessness. See infra notes 93-98 and accompanying text. Moreover, there is considerable debate as to whether immutability is required for a finding of heightened scrutiny. See infra Part IV.

6. See cases cited supra note 5 .

7. Let me be careful about what I am not saying. The fact that gays arrived at these ways of understanding themselves as a political movement, independent of the Equal Protection test, does not mean gays should be accorded heightened scrutiny. The way in which a movement presents itself may be self-serving, and this presentation, even if not directed at the Equal Protection test per se, cannot be a ground for granting or withholding heightened scrutiny under the Fourteenth Amendment. Indeed, this would constitute exactly the special pleading that the use of an "objective" test is meant to preclude. What I am arguing is that these symbols reflect truths that are directly responsive to the test, but that the conventional use of the test may not capture. 
gays have suffered a history of discrimination, the analogy that the pink triangle evokes between gays and Jews may drive home the nature of that persecution. When we consider whether gays are politically powerless, the closet may show how the gay community is divided by the closet door in a way that makes political mobilization for gays a problem different from what it may be for other disempowered groups. When we ask whether homosexuality is immutable (and whether we care), the body may enable us to think anew about how we conceive of both sexuality and mutability, given that it often stands as a metonym for both. More generally, such an analysis may force us to revise our understandings of the three prongs of the test itself, as the symbols engage them in unconventional dialogue. 8

\section{Discursive Disjunction}

In this Part, I first show how the assumption that "law coerces, while literature only persuades" justifies the separation of law and literature, and contend that this assumption does not always hold. I then argue that the Equal Protection Clause and symbols present a strong case for suspending that assumption and bridging the gap between the two fields.

\section{A. Why Law and Literature?}

An analysis of the impact of gay symbols on Equal Protection doctrine arises from two distinct discourses-literature and law-thereby situating this argument in the law-and-literature movement. ${ }^{9}$ Three views of the relationship between law and literature are particularly relevant here.

8. The discourse surrounding whether gays should receive heightened scrutiny has already enriched Equal Protection debates by raising hard questions about the meaning of the three prongs. As Cass Sunstein has shown, the question of whether Bowers necessarily forecloses heightened scrutiny for gays forces an examination of the role the history-ofdiscrimination prong is meant to play. See Cass R. Sunstein, Sexual Orientation and the Constitution: A Note on the Relationship Between Due Process and Equal Protection, 55 U. Chi. L. Rev. 1161, 1176 (1988). As Nan Hunter has noted, the ability of gays to be both "discrete and insular" and "anonymous and diffuse" has forced a reconsideration of the political-powerlessness prong. See Nan D. Hunter, Life After Hardwick, 27 Harv. C.R.-C.L. L. Rev. 531, reprinted in Sex Wars 85, 97 (Lisa Duggan \& Nan D. Hunter eds., 1995). Finally, as Janet Halley has shown, the "essentialist/constructivist" divide in gay studies has advanced the debate about the meaning of the immutability prong. See Janet E. Halley, Sexual Orientation and the Politics of Biology: A Critique of the Argument from Immutability, 46 Stan. L. Rev. 503, 506 (1994). These arguments and others are strengthened when contextualized by the argument from symbol.

9. The law-and-literature movement dates back to the publication of James Boyd White's The Legal Imagination in 1973. Robert Weisberg has subsequently divided the movement into two branches, law-in-literature and law-as-literature, a distinction that has been widely adopted. Law-in-literature considers literature about legal subjects (e.g., Kafka's The Trial, Camus's The Stranger, or Lee's To Kill a Mockingbird) and law about literature (e.g., defamation, obscenity, or copyright). Law-as-literature considers the applications of rhetoric and literary theory to the law. See Gretchen A. Craft, The Persistence of Dread in Law and Literature, 102 Yale L.J. 521, 523-24 \& nn. 6-7 (citing Robert Weisberg, The Law-Literature Enterprise, 1 Yale J.L. \& Human. 1, 36, 42 (1988)). 
The first, the "foundationalist" position, holds that law and literature should be considered distinct because an immanent difference exists between the two enterprises: law coerces while literature persuades. Although the sophisticated foundationalist position concedes that literature may affect the law indirectly by acting upon the human beings that make and apply it, that position nonetheless asserts that literature should have no direct role in legal argumentation. I focus on Richard Posner as one of the most prominent defenders of such sophisticated foundationalism. ${ }^{10}$ The second view rejects the proposition that an immanent distinction exists between law and literature, and blurs the boundary between the categories altogether. In launching his critique of Posner, Stanley Fish argues that the schism between law and literature is made rather than given. His critique invites radical permutations, and opens itself in turn to the charge of fostering anarchy. The third view can be seen as an uneasy compromise between the first two. It accepts that there is no immanent distinction between law and literature, but rejects the idea that there is therefore no useful distinction between the two fields. Owen Fiss champions this view.

1. Foundationalist Thesis. - Judge Posner, with refreshing brio, posits that "the study of literature has little to contribute to the interpretation of statutes and constitutions but ... it has something, perhaps a great deal, to contribute to the understanding and the improvement of judicial opinions." II According to Posner, this is because literature and law differ in their effects-literature persuades, while law coerces. As Posner notes: "The critic who interprets an ambiguous work of literature is not imposing his view on anyone else; the court that interprets an anbiguous provision ... is imposing its view on the rest of society, often with far-reaching practical consequences." ${ }^{2}$ Law's distinctive violence makes it necessary to quarantine the law away from other discourses. Insofar as legal actors understand the foreseeable violence of their words, they are apt to be more circumspect in the manner in which they deploy them. ${ }^{13}$ Those who operate in other discourses may be less socialized to constrain themselves in this way, because their discourses are definitionally less coercive.

This Article considers the use of literature to respond to a legal inquiry and thus implicates a third branch of the moveinent: literature-in-law.

10. I use the term "sophisticated foundationalism" to distinguish Posner's brand of foundationalism froin the "crude foundationalism" of, for example, Plato. See infra note 24.

11. Richard A. Posner, Law and Literature: A Relation Reargued, 72 Va. L. Rev. 1351, 1351 (1986).

12. Id. at 1373; see also Robert M. Cover, Violence and the Word, 95 Yale L.J. 1601, 1608 (1986) (distinguishing law from literature on the basis of law's violence).

13. Within the law, subdistinctions may be made on the same basis, with more coercive texts being more restrained than less coercive ones. For example, dissents often seem to partake of a more "literary" quality than majority opinions. This distinction may be explained by the fact that the dissenting judge knows she will not exert a directly coercive effect on the parties before her, but that she is writing in a merely persuasive capacity to convince judges in the future. I am indebted to Peter Brooks for this insight. 
Thus, free-wheeling literature may wreak havoc when allowed into the more violent realm of the law.

On the other hand, Posner argues that lawyers may benefit by learning the "craft values" of great literature: "descriptive scrupulousness, concreteness, and complexity, which I mean to stand for an awareness of the possibility of other perspectives than the writer's own."14 In arguing for such craft values, Posner notes that he makes a more limited version of James Boyd White's exhortation to "lawyers and judges to be more sensitive, candid, empathetic, imaginative, and humane."15 Literature may cultivate in judges certain qualities that make them better human beings. ${ }^{16}$ By doing so, it may have an indirect effect on the outcome of cases, even if it cannot have a direct one.

One striking example of both of Posner's views about law and literature-that literature may imdirectly influence law by plying its effects on judges but that law and literature should nonetheless remain distinct-is his own Plato-induced epiphany about homosexuality. In Sex and Reason, Posner describes how he read the Symposium "to plug one of the many embarrassing gaps in [his] education,"17 and how that experience changed his views on homosexuality:

I knew [the Symposium] was about love, but that was all I knew. I was surprised to discover that it was a defense, and as one can imagine a highly interesting and articulate one, of homosexual love. It had never occurred to me that the greatest figure in the history of philosophy, or for that matter any respectable figure in the history of thought, had attempted such a thing. It dawned on me that the discussion of the topic in the opinions in Bowers v. Hardwick . . . was superficial. ${ }^{18}$

We can be grateful for the conversion without surrendering concern about how it was effected. The impetus for Posner reading the Symposium is crucial and disturbing, for it shows on what a slender reed tolerance for homosexuality can rest. Posner did not read the Symposium to expand his views on homosexuality, but rather to "plug a gap" in his classical education. It was not until he had to reconcile his conception of the canonical status of "the greatest figure in the history of philosophy" with his conception of the non-canonical status of homosexuality that the latter faltered. ${ }^{19}$

Posner's account underscores that while judges generally will not use non-legal rhetoric, their determinations may be driven by subterranean

14. Posner, supra note 11 , at 1388 .

15. Id. at 1392 (citing James B. White, Law as Rhetoric, Rhetoric as Law: The Arts of Cultural and Communal Life, 52 U. Chi. L. Rev. 684 (1985)).

16. See id. at 1388.

17. Richard A. Posner, Sex and Reason 1 (1992).

18. Id. (referring to Bowers v. Hardwick, 478 U.S. 186 (1986)).

19. See id. 
emotions, assumptions, mythologies, epics, and scriptures. ${ }^{20}$ At the same time, Posner is careful to indicate that he can keep the literary and legal aspects of his reasoning distinct. While Posner notes that reading the Symposium reveals the majority opinion in Bowers to be "superficial,"21 he is at pains to note that he would not necessarily have reached a different decision. ${ }^{22}$ The Symposium speaks only to the literary qualities of the legal text-here primarily its tone-and not to its doctrinal aspects. In such a formulation, the effects of literature will necessarily be severely conscribed. Poets, to use Shelley's phrase, may be the unacknowledged legislators of the world, but they only achieve this power by being the legislators of the unacknowledged world. ${ }^{23}$ The sophisticated foundationalist concedes that judges are human and that literature will ply its effects on them as human beings, but suppresses the literary from legal discourse. ${ }^{24}$ This position thus precludes the Equal Protection argument from symbols.

2. Antifoundationalist Antithesis. - The postmodern response to foundationalism rejects the existence of an immanent distinction between law and literature by showing how the disciplinary distinction drawn between the two fields is made rather than given. Stanley Fish, responding to Posner, argues that while distinctions made between the two disciplines are both real and consequential, "their reality and their consequentiality are historical achievements-achievements fashioned on the anvil of argument and debate-and that as historical achieve-

20. See Robert M. Cover, Foreword: Nomos and Narrative, 97 Harv. L. Rev. 4, 4-5 (1983) (showing that law is embedded in a normative world, or nomos, of which literature is a constitutive part).

21. Posner, supra note 17 , at 1 .

22. See id. at 2 .

23. See Percy Bysshe Shelley, A Defence of Poetry (1840), reprinted in Shelley's Prose at 276, 297 (David L. Clark ed., corrected ed., 1966).

24. Posner's classical education, specifically that relating to Plato, may reveal itself in more ways than one in this account, for the foundationalist distinction he draws between law and literature is deeply akin to Plato's distinction between politics and poetics. In Book III of The Republic, Socrates banishes the poet from the polis even as he praises the poet as a "holy and wondrous and delightful creature." Plato, The Republic, Book III, at 398, in Plato: The Collected Dialogues (Edith Hamilton \& Huntington Cairns eds., 1961). The apparent paradox between adulation for and banishment of the poet can be resolved in that it is precisely because the poet is attractive that he is dangerous: in creating false forms and making them appear true, the poet seduces his audience away from the proper ideals of the state. Plato's distinction is foundational because it assumes both that there is a "true" form and that poetry is at a further remove than politics from this true form, see, for example, 1 I.M. Crombie, An Examination of Plato's Doctrines 13-14 (1962), thus positing an immanent (and tautological) distinction between poetry and politics. Posner's position is sophisticated foundationalism because it rejects Plato's definitive severance of law from literature. Posner concedes that literature has a place, albeit a limited one, in the law-he drives the poet underground rather than away. Yet what Posner advocates is foundationalism nonetheless, merely a subtler permutation of "law coerces, while literature persuades." Sophisticated foundationalism differs from crude foundationalism only insofar as it legitimates a wider ambit for literature's persuasive effects. 
ments they can be undone in much the same way as they were achieved."25 Under this formulation, the distinction Posner draws between coercive law and persuasive literature unravels (or can, if we undo it). This unravelling resolves a number of tensions in the foundational regime. First, it shows that laws are less coercive than they may seem. As Fish notes, all acts are interpretive acts: "All shapes are interpretively produced, and since the conditions of interpretation are themselves unstable-the possibility of seeing something in a 'new light,' and therefore of seeing a new something, is ever and unpredictably present." 26 Seen this way, the vision of a judicial act "beyond persuasion" is at best a deluded fantasy, at worst a deliberate mystification. ${ }^{27}$ Whether we perceive it as such, the judicial act is always an act of persuasion-the judge persuades the bailiff to take the prisoner away, the judge persuades the warden to carry out the sentence, the judge persuades the public not to riot in the streets and free the prisoner. That we cannot see these as acts of persuasion does not mean that they are not persuasive acts, but that they are deeply persuasive acts, acts that comprise "a discourse that has for historical reasons become associated with the presentation of truth." 28

Blurring the line between legal and literary discourse preserves the viability of an argument from symbols, but perhaps at too great a cost.

25. Stanley Fish, Doing What Comes Naturally 298 (1989).

26. Id. at 302.

27. See Cover, supra note 12, at 1609 (arguing that violence of judicial acts is "in need of no interpretation, no critic to reveal it").

28. Fish, supra note 25 , at 298 . The distinction between "coercive law" and "persuasive literature" may be challenged from the literary side as well, for literature may be more coercive than it seems. Fish adverts to the power of the canon, noting that a powerful critic "can have a profound and direct effect on what gets taught in the schools, what appears in the curriculum, what gains entrance into the canon, what gets published, reviewed, anthologized, disseminated." Id. at 306 . Through these effects, such a critic may "have an effect on the very structure of a culture, its favored myths, storehouse of moral values, modes of intellectual inquiry, etc." Id. Yet Fish notes that this constitutes only one of the ways in which the conventional distinction between law and literature can be contested. Id. Literature may have coercive effects that the law may never achieve, effects necessarily predicated on the permeability of an individual mind to its demands and blandishments, but more, rather than less, powerful for that. Most of us have at least one totemic text that has insinuated itself into our consciousness. One of mine concerns the coercive nature of literature itself. Upon reading Shakespeare's Sonnet 18, which concludes with the lines:

So long as men can breathe or eyes can see

So long lives this, and this gives life to thee.

William Shakespeare, Sonnet 18, in The Complete Works 851 (Stanley Wells et al. eds., 1986), I realized that I was complicit in carrying on the project of keeping the apostrophized mistress's name alive. I was the breathing man, mine were the eyes that saw. No one could call Shakespeare on his boast, because if the boast were empty, one would not know of it. For me to know of the boast was to have fulfilled it, for any effort to cast the lines away only inscribed them further into memory. It was an epiphany for me about the strength of language that this prophecy was self-fulfilling, that it had been transmitted from one reader to another, one editor to another, one publisher to another, so that the poet's Renaissance sentiment could make its way ineradicably into my contemporary mind. 
The liberating premise that no immanent distinction exists between law and literature inay lead to the alarming conclusion that anything "counts" as a legal argument. Fish refers to the notable omission of any mention of the Critical Legal Studies (CLS) movement in Posner's piece as an indication of a competing analysis that the piece needed to repress. ${ }^{29}$ However, CLS threatens Fish as well because it articulates the more radical permutations of his stance. Roberto Unger's work is particularly pertinent to this debate, insofar as Unger uses the literary trope of "Negative Capability" to attack foundationalism in law and other disciplines. ${ }^{30}$ By "Negative Capability," Unger means the poetic capacity to remain open to irrational elements, suspending the drive to reach rational conclusions. ${ }^{31}$ Unger's argument is that this literary idea can reveal the false necessity of foundational distinctions. ${ }^{32}$

If the price of foundationalism appears to be tautology, the price of Ungerian anti-foundationalism appears to be anarchy. Foundational distinctions respond to the very real fear that poets can seduce us away from rational political discourse. Unger eradicates those distinctions without providing alternative defenses against that fear. While he explicitly states that he does not advocate anarchy, ${ }^{33}$ Unger does not explain how what he advocates differs from it. While we ask him to tell us what a world without context might look like before we blithely tear down confining yet stabilizing hierarchies, Unger's only response appears to be that we cannot know what that world will look like because we constantly will be recreating it. ${ }^{34}$

3. Unstable Synthesis. - For those skeptical of Posner's and Unger's conflicting stances, the challenge is to recuperate some distinction between law and literature without relying on an immanent distinction between them. Owen Fiss does precisely this when he states that the "bounded objectivity of interpretation" is not "a secondary or parasitic kind of objectivity." 35 Indeed, Fiss argues: "Bounded objectivity is the only kind of objectivity to which the law-or any interpretive activityever aspires and the only one about which we care. To insist on more, to search for the brooding omnipresence in the sky, is to create a false issue." 36 Fiss thus attempts to distinguish between the idea that no immanent distinction exists and the idea that no valid distinction exists. To concede the former, he argues, is not to concede the latter. Even if we

29. See Fish, supra note 25 , at 307 .

30. See Roberto Mangabeira Unger, Social Theory: Its Situation and It's Task 155-56 (1987) [hereinafter Unger, Social Theory]; Roberto Mangabeira Unger, False Necessity: Anti-Necessitarian Social Theory in the Service of Radical Democracy 277-312 (1987).

31. See sources cited supra note 30 .

32. See Unger, Social Theory, supra note 30 at $156-57$.

33. See id. at 154-55.

34. See id. at 159.

35. Owen M. Fiss, Objectivity and Interpretation, 34 Stan. L. Rev. 739, 745-46 (1982).

36. Id. (citing Southern Pac. Co. v. Jensen, 244 U.S. 205, 222 (1916) (Holmes, J., dissenting). 
must make, rather than detect, the distinction between law and literature (for example) we still can make it well.

The case made in this Article proceeds from a Fiss-like theory, and at a cautious pace. It makes no sweeping claims about what the relationship between law and literature should be. Its modest ambition is to chart a middle course between the equally false pieties of foundationalism and anti-foundationalism by interrogating attempts to make or blur distinctions between law and literature on a case-by-case basis.

\section{B. Why Equal Protection and Symbols?}

I have mapped the large and contested theoretical terrain on which law and literature converse in part to situate the small and defensible plot on which my argument takes place. While law and literature may veer apart in many ways, using gay symbols to make an argument about gay Equal Protection doctrine is a case in which they come quite close. On the "legal" side, the Equal Protection Clause invites the use of the humanities. On the "literary" side, symbols evade many of the difficulties associated with other literary forms, and provide valuable insights into legal doctrine.

1. Equal Protection Clause. - Any discussion of the Equal Protection Clause necessarily implicates John Hart Ely's seminal theory of processbased judicial review, ${ }^{37}$ which, in its turn, exfoliates the fainous fourth footnote of United States v. Carolene Products Co. ${ }^{38}$ While critics profess to be confounded by the "puzzling persistence of this view,"39 I focus here less on the puzzlement of the critics than on the persistence of the theory. In other words, I evade the prescriptive debate about the merits of the theory by brandishing the brute fact that the courts employ it. I take it as axiomatic that the Carolene Products footnote, and the theory it describes, have worked their way into the consciousness of the American

37. See generally John Hart Ely, Democracy and Distrust (1980).

38. 304 U.S. 144, 152 n.4 (1938). The footnote reads, in pertinent part:

Nor need we enquire whether similar considerations enter into the review of statutes directed at particular religious, ... or national, . . . or racial minorities, ...: whether prejudice against discrete and insular minorities may be a special condition, which tends seriously to curtail the operation of those political processes ordinarily to be relied upon to protect minorities, and which may call for a correspondingly more searching judicial inquiry.

Id. (citations omitted).

39. See Laurence H. Tribe, The Puzzling Persistence of Process-Based Constitutional Theories, 89 Yale L.J. 1063, 1063-64 (1980) (noting how process-based theory of constitutional law actually masks substantive decisionmaking); see also, e.g., Paul Brest, The Fundamental Rights Controversy: The Essential Contradictions of Normative Constitutional Scholarship, 90 Yale L.J. 1063, 1064-65 (1981) (noting that "processoriented strategies [are] covertly value-laden"); Lea Brilmayer, Carolene, Conflicts, and the Fate of the "Inside-Outsider," 134 U. Pa. L. Rev. 1291, 1292 (1986) (arguing that Carolene Products rhetoric concealed controversial assumptions). 
judiciary, and form the text or subtext of many decisions made under the Equal Protection Clause. ${ }^{40}$

Ely's Carolene Products-inflected argument for judicial review (as summarized by Bruce Ackerman) is as follows: democracies run on a theory of minority acquiescence. Therefore, a minority group cannot expect to win in many cases, even where it feels deeply wronged by the legislative majority. ${ }^{41}$ On the other hand, no single minority block should lose consistently. Majorities are not monolithic, but comprised of unstable coalitions of minorities fashioned through pluralistic bargaining. Thus, every minority should have its day. ${ }^{42}$ If a minority loses consistently, the court must determine whether that minority is disadvantaged in the bargaining process. If the minority is found to be disadvantaged, then the court should strike down the legislative determination of the majority. ${ }^{43}$ The judiciary does so not on the basis of the fact that it disagrees with the substance of the determination, but rather because it seeks to correct the tainted process through which the majority arrived at that determination. The genius of this formulation is that the court takes the processual high ground as a referee rather than assuming the substantive low ground as a player. ${ }^{44}$ Under Carolene, it is the legislature, not the court, that has created the legitimacy deficit, and by correcting that deficit, the court preserves, rather than breaks, faith with the majoritarian political process. ${ }^{45}$ Ely therefore touts the Carolene footnote as the lodestar that allows the court to chart a course between the Scylla of clause-bound interpretivism and the Charybdis of unconstrained countermajoritarian decisionmaking. 46

This process-based theory of judicial review is built on the concept of empathy failure. The Equal Protection Clause inust shelter a particular group because it suffers a disadvantage in the political bargaining process. This disadvantage is empathy failure-the group's inability to make

40. Justice Powell noted that "the influence of Footnote 4 cannot be measured accurately by simple enumeration of cases in which it has been cited." Lewis F. Powell, Jr., Carolene Products Revisited, 82 Colum. L. Rev. 1087, 1087 n.4 (1982). Bruce Ackerman has concluded that even when not cited explicitly, the footnote stands as a justification for the heightened judicial scrutiny of legislation burdening "suspect" classes. See Bruce A. Ackerman, Beyond Carolene Products, 98 Harv. L. Rev. 713, 716 n.5 (1985). But see Daniel A. Farber \& Philip P. Frickey, Is Carolene Products Dead? Reflections on Affirmative Action and the Dynamics of Civil Rights Legislation, 79 Cal. L. Rev. 685, 691-97 (1991) (arguing that, despite academic argument to the contrary, Carolene Products is not used frequently by the Supreme Court).

41. See Ackerman, supra note 40, at 719.

42. See id. at 720.

43. See id.

44. See id. The Carolene Products Court's processual justification for judicial review may be seen as an attempt to evade the substantive due process arguments that had led to its rout in Lochner jurisprudence. See id. at 719.

45. See id. at 720.

46. See Ely, supra note 37, at 75-77 (discussing the way in which the three paragraphs of footnote 4 reflect both roles for the Court). 
its claims sympathetic to potential bargaining partners. Where the judiciary identifies such a failure of empathy, it has the right-indeed the obligation-to intervene and correct the political process.

Critics are puzzled by the persistence of Carolene Products because they find its ostensible movement away from substantive decision-making a sham. ${ }^{47}$ They note that while the Carolene Products formulation presents itself as processual, substantive values nevertheless secrete themselves in the interstices of its inquiry. ${ }^{48}$ For example, in determining whether a political process was "pure," the reviewing court must determine whether other groups refuse to deal with a given minority out of principle or prejudice. ${ }^{49}$ Given that one person's principle is another's prejudice, the court has to make a substantive determination as to which is involved.50 Ely's response to this criticism is that judges are relative outsiders to the political system, and are more experienced in examining failures of process. 51 Therefore, they are more likely to be in a position to assess the difference between principle and prejudice. ${ }^{52}$ While such determinations are subjective, Ely argues, they are made at one remove from the hurly-burly of legislative politics, and that distance may have a clarifying effect. 53

Ely's response answers one question and begs others, namely, what happens when the judge does not have this critical distance? What happens when the judge shares the exact prejudice that created empathy failure on the part of the legislator? While the judge nay achieve certain kinds of distance from the legislator, there is no reason to think that she will not occasionally share the same blindness. And there's the rub: how can a judge see a blindness she shares?

Judges interpreting the Equal Protection Clause have responded to this problem by asking whether they themselves, rather than simply the legislature, suffer from empathy failure for the group in question. They have done so by crafting a three-prong test that forces judges to take a sober second look at fundamentals of that group's identity. That second

47. See, e.g., Tribe, supra note 39 , at $1064-65$ (" $[\mathrm{I}] \mathrm{t}$ is not difficult to sbow that the constitutional theme of perfecting the process of governmental decisionmaking is radically indeterminate and fundamentally incomplete.").

48. See, e.g., id. ("The process theme by itself determines almost nothing unless its presuppositions are specified, and its content supplemented, by a full theory of substantive rights and values-the very sort of theory the process-perfecters are at such pains to avoid.").

49. See Ackerman, supra note 40 , at 737 .

50. See id.

5I. See Ely, supra note 37, at 103.

52. See id. In City of Cleburne v. Cleburne Living Ctr., Inc., 473 U.S. 432, 472-73 n.24 (1985), Justice Marshall provided another rationale for why judges are "well suited" to the task of identifying "discrete and insular" minorities. He argued that judges, by virtue of the "lessons of history and experience" that their profession has given them, have the best guides for when "society is likely to stigmatize individuals as members of an inferior caste or view them as not belonging to the community." Id.

53. See Ely, supra note 37, at 103. 
look attempts to diminish the possibility that judges will express the same prejudice as the legislature by forcing them to come to terms with the nature of the group. Through that engagement, judges are prompted to interrogate their assumptions about the group in a way that the legislature is not.

That one of the purposes of the test is to inspire understanding on the part of judges by forcing them to work exercises in empathy makes literary understanding immediately relevant. For literature is nothing if not such a source of empathetic imagining. Martha Nussbaum defends "the literary imagination precisely because it seems ... an essential ingredient of an ethical stance that asks us to concern ourselves with the good of other people whose lives are distant from our own." 54 As she notes, "an ethics of impartial respect for human dignity will fail to engage real human beings unless they are made capable of entering imaginatively into the lives of distant others and to have emotions related to that participation." 55

2. Symbols. - While the Equal Protection Clause extends its invitation to literature generally, it will be more receptive to some literary genres than others-particularly the symbol. In order to show this, I contrast the symbol to the novel, which some commentators see as the literary form most able to evoke empathy. ${ }^{56}$ Nussbaum defends her focus on novels in her discussion of empathy in public rationality by noting three distinguishing characteristics of the novel-its imaginative, particularistic, and emotional aspects. These virtues, however, can transmute into their nearest vices, which, as formulated by Daniel Farber and Suzanna Sherry, are literature's untrue, unrepresentative, and non-analytic aspects. ${ }^{57}$ I knit together Nussbaum with Farber and Sherry to provide a (1995).

54. Martha Nussbaum, Poetic Justice: The Literary Imagination and Public Life xvi

55. Id. The connection between the empathy required by the Carolene Products analysis and that prompted by literary works has not gone unnoticed. In the gay context, one federal court invoked the Carolene Products footnote as the text that "has set the tone for the Supreme Court's consideration of all threats to the exercise of minorities' constitutional rights." Adolph Coors Co. v. Wallace, 570 F. Supp. 202, 209 n.24 (N.D. Cal. 1983). In the same analysis, it chided the magistrate judge whose decision it was reviewing for failing to take seriously affidavits in which gay plaintiffs narrated their "experience with 'coming out of the closet,' in various professional and social settings." Id. The court noted that these stories were relevant to the doctrinal inquiry mandated by the Equal Protection Clause. Id.

56. As Richard Rorty notes:

The process of coming to see other human beings as "one of us" rather than as "them" is a matter of detailed description of what unfamiliar people are like and of redescription of what we ourselves are like. This is a task not for theory but for genres such as ethnography, the journalist's report, the comic book, the docudrama, and, especially, the novel.

Richard Rorty, Contingency, Irony, and Solidarity xvi (1989); see also Nussbaum, supra note 54, at 5-10 (discussing the novel as a prime literary source of empathetic imagining).

57. See Daniel A. Farber \& Suzanna Sherry, Telling Stories out of School: An Essay on Legal Narratives, 45 Stan. L. Rev. 807, 809 (1993). 
balanced portrait of the benefits and drawbacks of the novel as a medium for empathy in the law. I then argue that while symbols retain many of the benefits of the novel, they avoid many of its drawbacks.

In defending the novel, Nussbaum first argues that the fictional nature of novels make them fields of greater possibility than history or biography by relieving them from the constraints of reality:

Literary art, [Aristotle] said, is "more philosophical" than history, because history simply shows us "what happened," whereas works of literary art show us "things such as might happen" in a human life. In other words, history simply records what in fact occurred, whether or not it represents a general possibility for human lives. Literature focuses on the possible, inviting its readers to wonder about themselves. ${ }^{58}$

Politics is often described as the art of the possible. Nussbaum points out that literature is the art of the possible as well, but in the opposite sense. While politics emphasizes realistic possibility, literature emphasizes unrealistic possibility, by allowing us to inhabit other lives as if they were our own.

Yet fiction's ability to project us beyond the actual into the possible makes fiction a poor empirical base. As Farber and Sherry note:

The more fictionalized the story, however, the more troublesome its use as empirical evidence becomes. Relying on fiction as evidence is rather like an episode recounted by Patricia Williams: "An image that comes to mind is that of movie star Jessica Lange, who testified to Congress about the condition of farms in the United States because she had played a farmer's wife. What on earth does 'testimony' mean in that context?"59

Lange's performance in the film enacts a "possibility" rather than an actuality; when we watch the film we do not believe that she is a farmer's wife, but we are willing to suspend our disbelief and enter into the world in which she is one. What jars about Lange's testimony in Congress is that these very suspensions of reality-I am going to empathize with a farmer's wife by watching a woman who I know is not a farmer's wife play a farmer's wife-so commonplace in art, seem out of place in policymaking. Here the ductility of stories, their ability to represent what is not true as if it were, is cast as a form of "research fraud: doctoring data to fit your thesis." 60

Nussbaum next points out that the novel is particular rather than general, giving faces to forms that would otherwise remain abstract:

[T] he novel is concrete to an extent generally unparalleled in other narrative genres. It takes as its theme, we might say, the interaction between general human aspirations and particular

58. Nussbaum, supra note 54 , at 5 (footnote omitted).

59. Farber \& Sherry, supra note 57, at 832 (quoting Patricia J. Williams, The Alchemy of Race and Rights 30-31 (1991)).

60 . Id. at 834 . 
forms of social life that either enable or impede those aspirations, shaping them powerfully in the process. Novels (at least realist novels of the sort I shall consider) present persistent forms of human need and desire realized in specific social situations. ${ }^{61}$

The novel is "concrete," "particular" and "specific." It draws us into a protagonist's life. It does not seek to detach us as judges of a protagonist's claim, but gives us access to her felt experience.

But involvement in the particulars of an individual story may prevent us from performing the necessary aggregation of interests essential to public decisionmaking. As Farber and Sherry note:

[I]f the story is being used as the basis for recommending policy changes, it should be typical of the experiences of those affected by the policy. Owen Fiss has cogently argued that when the Supreme Court "lays down a rule for a nation ... [it] necessarily must concern itself with the fate of millions of people .... Accordingly, the Court's perspective must be systematic, not anecdotal ...."62

The ability of stories to draw in a reader, to make them see things through the lens of the protagonist, endangers a decisionmaker's ability to weigh competing claims. ${ }^{63}$ Paul Gewirtz points out the naiveté of privileging storytelling against conventional lawmaking by noting that stories inevitably contradict one another and that celebrating storytelling in itself does not empower us to arbitrate fairly between them. ${ }^{64}$ The plural of anecdote is not data.

Nussbaum's third defense of the novel is that its appeal to our emotions allows it to disentrench traditionally held assumptions:

" $[G]$ ood literature is disturbing in a way that history and social science writing frequently are not. Because it summons powerful emotions, it disconcerts and puzzles. It inspires distrust of conventional pieties and exacts a frequently painful confrontation with one's own thoughts and intentions. One may be told many things about people in one's own society and yet keep that knowledge at a distance. Literary works that promote identification and emotional reaction cut through those self-protective stratagems, requiring us to see and to respond to many things that may be difficult to confront-and they make this process palatable by giving us pleasure in the very act of confrontation. ${ }^{65}$

61 . Nussbaum, supra note 54 , at 7 .

62. Farber \& Sherry, supra note 57, at 838-39 (quoting Owen M. Fiss, Reason in All Its Splendor, 56 Brook. L. Rev. 789, 802-03 (1990)).

63. See Martha Minow, Surviving Victim Talk, 40 UCLA L. Rev. 1411, 1435 (1993) (" $[T]$ here is a risk that emphasizing individual stories and stressing feelings can undermine critical evaluation and analysis of contradictory claims."); see also Craft, supra note 9, at 528 (1992) (noting that "unfiltered emotion, in case after case, would jade observers' sympathy and distort even the attempt at impartiality").

64. See Paul Gewirtz, On "I know It When I See 1t," 105 Yale L.J. 1023, 1045 (1996).

65 . Nussbaum, supra note 54 , at 5-6. 
For many scholars, this aspect of literature contributes the most to legal discourse. As Richard Delgado notes: "Stories, parables, chronicles, and narratives are powerful means for destroying mindset-the bundle of presuppositions, received wisdoms, and shared understandings against a background of which legal and political discourse takes place. . . Stories can shatter complacency and challenge the status quo."66

An emotion, however, is not an argument. While those who tout the effects of stories emphasize their ability to destabilize the status quo, they often fail to note that their own move can often be perceived as equally hegemonic. Farber and Sherry make up that lack:

Without reasoned arguments, neither understanding nor dia-

logue are likely to flourish. Robin West refers to the "unequivocal shock of recognition" upon reading certain articles, and Kathryn Abrams believes Patricia Williams' stories because they "resonate" with her experiences. But for those readers who neither resonate nor recognize, and for those who passionately disagree, there is no way to enter the dialogue. Thus, as Gerald Torres says, unless augmented by analysis, storytelling may "function as an authoritarian conversation-ending move." 67

Storytelling advocates often emphasize the exclusive aspects of rationality as a mode of discourse that favors insiders. Yet the aesthetic response that stories elicit is exclusive as well, winnowing those who respond from those who do not, those who see from those who cannot. Moreover, as a inedium that requires emotive responses, literature may be less permeable to effort. As conventionally told, one can learn and replicate a logical argument, but one does not epiphanize one's way to an epiphany.

Nussbaum's impassioned defenses and Farber and Sherry's attacks seem to present an impasse. The symbol, however, may provide a resolution because it captures many of the benefits of the novel without falling prey to many of its drawbacks. First, truth-verification is not a problem for symbols as it is for stories. The truth-verification concern relates to whether the person's story is an accurate depiction of reality: Did iny anecdote about the appellate judge actually happen as I described it? Yet when we question whether a symbol actually represents its referent, we are not asking whether the person who propounded the syinbol was "telling the truth" about it, because that person does not exist. Symbols are definitionally the creations of communities rather than individuals: "[t] he individual can devise signs for his own private needs; he cannot make symbols." 68 While we can contest the inisuse of symbols-as when,

66. Richard Delgado, Storytelling for Oppositionists and Others: A Plea for Narrative, 87 Mich. L. Rev. 2411, 2413-14 (1989); see also Steven L. Winter, The Cognitive Dimension of the Agon Between Legal Power and Narrative Meaning, 87 Mich. L. Rev. 2225, 2228 (1989) ("[T] he highest use and greatest facility of narrative is as an inconoclastic tool of persuasion to legal and social change.").

67. Farber \& Sherry, supra note 57, at 851 (footnotes omitted).

68. Paul Tillich, The Religious Symbol, in Symbolism in Religion and Literature 75, 77 (Rollo May ed., 1960). 
for example, Susan Sontag resists warmaking metaphors as means of describing disease ${ }^{69}$ - the criticism in such cases is not that any individual is fabricating a story, but rather that a group is engaging in a destructive discourse.

Second, and relatedly, symbols are definitionally representative. Symbols are "socially rooted and socially supported" in a way that individual stories are not; they are by their nature aggregations of desires and meanings that exist within a community. ${ }^{70}$ Indeed, the symbol may sacrifice particularity in order to be representative. ${ }^{71}$ Many symbols, such as the American flag, derive their ability to draw together communities of adherents precisely because they do not force believers to articulate what it is about the symbol that draws them together. ${ }^{72}$ Such an articulation doubtless would fracture an otherwise unified community, for the overdetermined signifier of the flag accommodates both the nationalism of the xenophobe (America is not like other countries) and the pluralism of the liberal (America is like all other countries). The symbol subsumes plural meanings in order to have plural appeal; ${ }^{73}$ quite magically, however, this apparent watering-down of meaning does not have a dilutive effect on the power of the symbol, as the varied yet visceral voices raised against flag-burning reveal. As Chief Justice Rehnquist has noted, many Americans approach the flag "with an almost mystical reverence regardless of what sort of social, political, or philosophical beliefs they may have."74

Whether symbols are more "analytic" than stories is a fascinating question. On the one hand, symbols can be seen as communicating in a direct and visceral way not associated with rational thought. There is an "all-at-onceness" to the perception of the symbol that gives it a stronger presence; as Abbé Du Bos said: "We may say here, metaphorically speaking, that the eye is nearer to the soul than the ear."75 This "all-at-onceness" reveals the fallacy underlying the First Amendment truism that those who do not like a visual sign can avoid it "simply by averting their eyes."76 Once the viewer perceives a symbol, she cannot defeat its impact simply by avoiding a second glance. This "all-at-onceness" is recognized

69. See Susan Sontag, AIDS and Its Metaphors 10-11 (1989).

70. See Tillich, supra note 68 , at 76-77.

71. See David I. Kertzer, Ritual, Politics, and Power 11 (1988).

72. See id.

73. Symbols, at least visual symbols, may be comprehensible to all, without regard to nationality or education, while "the curse of Babel works against poetry." Tzvetan Todorov, Theories of the Symbol 131 (Catherine Porter trans., Cornell Univ. Press 1982) (1977). The symbol, therefore, is available for more widespread consumption.

74. Texas v. Johnson, 491 U.S. 397, 429 (1989) (Rehnquist, C.J., dissenting).

75. Todorov, supra note 73, at 131 (quoting Abbé Du Bos, Critical Reflections on Poetry, Painting and Music (1719) (Thomas Nugent trans., 1978) (1719)).

76. Cohen v. California, 403 U.S. 15, 2 I (1971). 
by cases in which symbols are characterized as immediate incitements to action. ${ }^{77}$

Yet this aspect of symbols is not implicated by Farber and Sherry's critique about the non-analytic nature of the story, which argues that only those predisposed to have an emotional response would be affected by it. While symbols may be shibboleths that exclude others, they are generally more accessible than stories, precisely because they need to be public signifiers in order to accomplish their purpose. In describing the AIDS logo, the slogan SILENCE=DEATH under a pink triangle, Douglas Crimp and Adam Ralston note that:

[I] $\mathrm{t}$ is not merely what SILENCE=DEATH says, but also how it looks, that gives it its particular force. The power of this equation under a triangle is the compression of its connotation into a logo, a logo so striking that you ultimately have to ask, if you don't already know, "What does that mean?" And it is the answers we are constantly called upon to give to others-small, everyday direct actions-that make SILENCE=DEATH signify beyond a community of lesbian and gay cognoscenti. ${ }^{78}$

The effectiveness of the symbol is thus predicated on the fact that people expect to understand symbols, such that they will ask about those they do not recognize. Because symbols are for public consumption, ${ }^{79}$ for the illiterate as well as the literate, for the masses as well as for the cognoscenti, their emotive aspect must be less exclusive.

It is for such reasons that Hannah Pitkin views political representation and symbolic representation as sharing the common goal of "making present something which is not there," which is the root of the word representation. ${ }^{80}$ This view allows us to see both animate persons and inanimate objects as representatives of certain communities. Thus Barney Frank, a gay Congressman, and a pink triangle, a gay symbol, can both be seen to "speak for" the gay community. Both are accountable to their

77. See, e.g., Anderson v. Vaughan, 327 F. Supp. 101, 106 (D. Conn. 1971) (Clarie, J., dissenting) (noting the inherently provocative nature of Ku Klux Klan, Nazi, and Viet Cong flags); Village of Skokie v. National Socialist Party of Am., 366 N.E.2d 347, 357 (Ill. App. Ct. 1977), rev'd in part, 373 N.E.2d 21 (Ill. 1978) ("[T] he tens of thousands of Skokie's Jewish residents must feel gross revulsion for the swastika and would immediately respond to the personally abusive epithets slung their way in the form of the defendants' chosen symbol, the swastika.").

78. Douglas Crimp \& Adam Rolston, AIDS Demo Graphics 14 (1990).

79. In the Skokie case, the Illinois Appellate Court drew a distinction between uniforms and symbols, stating that the former were protected under the First Amendment but the latter were not. See Village of Skokie, 366 N.E.2d, at 354. This part of the opinion, later struck down by the state supreme court, would have allowed persons without swastikas wearing Nazi storm trooper uniforms to march in a parade, but not those wearing the swastika, even if not wearing an SS uniform. The court justified this position by noting that the symbol was more likely to incite violence than the uniform. See id. The court's intuition was that symbols communicated an idea that could incite reaction much more readily than a uniform. See id. at 354-57.

80. See Pitken, supra note 4 , at 8-9, 226-27. 
constituencies-if either fails to "represent" that community, it is understood that another "representative" will come and take their place. And it is through this accountability that they attain their legitimacy. The best reading of the Equal Protection Clause as a device meant to protect against bias by forging an understanding of communal identity should thus ask the judge to be open to that community's symbols. By definition, if a community is disempowered in the political bargaining process, there will not be as many Barney Franks as there should be, and the Barney Franks will not be heard on their issues. One alternative route to discovering that identity is to look to its other representatives-its symbols.

While the attempt here has been to question resistance to a merger of doctrine and symbol at a high level of abstraction, that resistance can be assailed at a more particular level-that of triangles, closets, and bodies.

\section{History of Discrimination and the Pink Triangle}

\section{A. History of Discrimination}

The first prong of the Equal Protection Clause test asks whether the group in question has suffered a history of discrimination. While courts have interpreted the second and third prongs to defeat the claims of the gay community for heightened protection, every court to consider the issue has concluded that gays satisfy the first one. ${ }^{81}$ This prong may thus seem a strange place to start arguing that an examination of symbols would permit a better legal understanding of gays. The consensus of the courts seems to moot the issue-what more can gay-rights advocates ask for than such clear wins?

A lot. First, while every court to engage in the inquiry has concluded that gays have suffered a history of discrimination, many have not reached the inquiry because they consider it pre-empted by Bowers $v$. Hardwick. ${ }^{22}$ Given that this unwillingness to entertain a gay Equal Protec-

81. See, e.g., Equality Found. Inc. v. City of Cincinnati, 860 F. Supp. 417, 436-37 (S.D. Ohio 1994) (concluding that "gays, lesbians and bisexuals have suffered a history of invidious discrimination based on their sexual orientation"), rev'd on other grounds, 54 F.3d 261 (6th Cir. 1995), vacated and remanded, 116 S. Ct. 2519 (1996); Jantz v. Muci, 759 F. Supp. 1543, 1548-49 (D. Kan. 1991) ("Homosexuals in the United States have historically been subjected to discrimination both pervasive in its scope and intense in its impact."), rev'd on other grounds, 976 F.2d 623 (10th Cir. 1992); High Tech Gays v. Defense Indus. Sec. Clearance Office, 668 F. Supp. 1361, 1369-70 (N.D. Cal. 1987) ("Lesbians and gay men have been the object of some of the deepest prejudice and hatred in American society."), rev'd on other grounds, 895 F.2d 563 (9th Cir. 1990).

82. See, e.g., Equality Found. v. City of Cincinnati, 54 F.3d 261, 268 (6th Cir. 1995) ("Bowers $v$. Hardwick and its progeny command that, as a matter of law, gays, lesbians, and bisexuals cannot constitute either a 'suspect class' or a 'quasi-suspect class' ... . "), vacated and remanded, 116 S. Ct. 2519 (1996); Steffan v. Perry, 41 F.3d 677, 684 n.3 (D.C. cir. 1994) (en banc) ("II]f the government can criminalize homosexual conduct, a group that is defined by reference to that conduct cannot constitute a 'suspect class' "); Ben-Shalom v. 
tion claim may stem in part from anti-gay bias, these courts are perhaps the ones most in need of this analysis. Second, many courts that do engage in the historical inquiry treat it in a perfunctory manner, appearing to check the mental "yes" box by the question, "Has this group suffered political persecution?" before going on to deny gays heightened scrutiny. ${ }^{83}$ The speed with which a court checks an uncontroversial box may seem unproblematic, but such an approach runs counter to the spirit of the inquiry mandated by the Equal Protection Clause, with serious practical consequences.

To understand how a perfunctory concession that gays have satisfied the prong breaks faith with the purposes of the Equal Protection Clause, we must understand how the Equal Protection Clause test's use of history differs from that of the law in general. Cass Sunstein notes that "in its judicial interpretation, the [Due Process Clause] has frequently been understood as an effort to restrict short-term or shortsighted deviations from widely held social norms; it has an important backward looking dimension." 84 Sunstein shows that the Equal Protection Clause, in contrast, considers history for the purpose of determining whether to break from it:

Since its inception, the Equal Protection Clause has served an entirely different set of purposes from the Due Process Clause. The Equal Protection Clause is emphatically not an effort to protect traditionally held values against novel or short-term deviations. . . . The clause is not backward-looking at all; it was selfconsciously designed to eliminate practices that existed at the time of ratification and that were expected to endure.

... [T] he Equal Protection Clause is not rooted in common law or status quo baselines, or in Anglo-American conventions. The baseline is instead a principle of equality that operates as a criticism of existing practice. The clause does not safeguard traditions; it protects against traditions, however long-standing and deeply rooted. 85

The Equal Protection Clause thus inverts the custom of adhering to the past that the Due Process Clause in particular, and the law in general, follow. For the variable of history, the strength of argnments made under each of the Clauses will be inversely related-if a history of "discrimina-

Marsh, 881 F.2d 454, 464 (7th Cir. 1989) ("If homosexual conduct may constitutionally be criminalized, then homosexuals do not constitute a suspect or quasi-suspect class entitled to greater than rational basis scrutiny for equal protection purposes."); Woodward v. United States, 871 F.2d 1068, 1076 (Fed. Cir. 1989) ("After Hardwick it cannot logically be asserted that discrimination against homosexuals is constitutionally infirm."); Padula v. Webster, 822 F.2d 97, 103 (D.C. Cir. 1987) (finding that reasoning in Bowers and precedent in circuit "forecloses appellant's efforts to gain suspect class status for practicing homosexuals").

83. See, e.g., High Tech Gays, 895 F.2d at 573 (finding "history of discrimination" an insufficient ground for application of heightened scrutiny).

84. Sunstein, supra note 8 , at 1171 .

85. Id. at 1174. 
tion" is well-established, the Due Process claim will be weaker and the Equal Protection claim will be stronger, and vice versa.

For our purposes, the most important difference between the two uses of history is how each implicates the epistemology of the decisionmaker. As conventionally told, judges often abdicate their own subject position in the face of the law. ${ }^{86}$ While this abdication may be seen in judges' approaches to the law generally, it finds particular expression in judicial attitudes toward history. ${ }^{87}$ Through this abdication, judges often seem to dissolve as decisionmakers-it is the precedent that commands a given result, not their own sentiments. This allows them to evade accountability for their own views, even when those views depart significantly from what is strictly required by precedent. ${ }^{88}$ Under Sunstein's theory, the Due Process Clause is in harmony with the legal tradition of following the past, and therefore with the tradition of the judge whose subjective viewpoint disappears into the woodwork of doctrine. ${ }^{89}$ The Equal Protection Clause, in contrast, makes that decisionmaker sharply visible. It asks the judge whether the history of discrimination suffered by a group indicates that it might suffer incommensurate harms in the political bazaar. In making this determination, the judge must consider the mindset of the legislator to ascertain whether the legislator experienced empathy failure in dealing with this group. As noted earlier, that determination necessarily implicates the mindset of the judge, for one is unlikely to see another's blindness if one shares it. ${ }^{90}$

This focus on the judge's subject position implicit within the history prong of the Equal Protection test places an additional burden on the court to engage in a reflective, rather than a reflexive, response when considering the claims of a group. In order to meet that burden, a court should not be able simply to dismiss a claim as facetious. Nor should it be able simply to "check a box," even in a way that is favorable to the group, and move on. Rather, it should display some notion of the history experienced by the group, and an unwillingness to allow that history to continue by default. Considering the Equal Protection claims of illegitimate children in Mathews $v$. Lucas, Justice Stevens noted in dissent that:

Because of that tradition of disfavor the Court should be especially vigilant in examining any classification which involves ille-

86. This axiom perhaps finds its most famous expression in Marbury v. Madison, 5 U.S. (1 Cranch) 137, 163 (1803): "The government of the United States has been emphatically termed a government of laws, and not of men."

87. See, e.g., Planned Parenthood v. Casey, 505 U.S. 833, 860 (1992) (opinion of O'Connor, Kennedy, and Souter, JJ.) (relying on stare decisis to uphold abortion rights).

88. See Casey, 505 U.S. at 993-94 (Scalia, J., dissenting) ("I suppose the Court is entitled to call a 'central holding' whatever it wants to call a 'central holding'-which is, come to think of it, perhaps one of the difficulties with this modified version of stare decisis.").

89. See Sunstein, supra note 8 , at 1163.

90. See supra text accompanying notes $53-55$. 
gitimacy. For a traditional classification is more likely to be used without pausing to consider its justification than is a newly created classification. Habit, rather than analysis, makes it seem acceptable and natural to distinguish between male and female, alien and citizen, legitimate and illegitimate; for too much of our history there was the same mertia in distinguishing between black and white. ${ }^{91}$

Justice Stevens's distrust of tradition comports with Sunstein's theory of the history prong as a heuristic device that forces the judicial decisionmaker to consider his potential complicity in the oppression he examines. Under this theory the decisionmaker must engage the biography of a group to determine the nature of its suffering. 92

A more pragmatic argument supplements the principled contention that judges who check a box are violating the spirit of the test. As a practical matter, a flawed reading of the history prong may adversely affect analysis under the other two prongs. Those "trickle over" effects may in turn determine the ultimate outcome of the Equal Protection inquiry as a whole. In fact, many courts considering the issue check the "yes" box for the history of discrimination and then deny gays heightened scrutiny on other grounds. ${ }^{93}$ While this "trickle over" is often subtle, explicit exam-

91. Mathews v. Lucas, 427 U.S. 495,520 (1976) (Stevens, J., dissenting).

92. A collateral benefit of this reading is that it resolves the potential redundancy of the history prong with the political-powerlessness prong. Assuming that the best reading of the Equal Protection Clause is as an instrument that calibrates and corrects empathy failure, an inquiry into the current political powerlessness of the group seems the most direct way of achieving its ends. Indeed, a supplemental inquiry into the group's history of discrimination (or immutability) seems redundant. After all, if a group is currently politically powerful, then it should not be accorded greater solicitude by the courts, even if it has historically suffered discrimination. Its political power should allow it to engage in self-help through the pursuit of legislative redress. Conversely, if a group has not suffered a history of discrimination but is currently politically powerless, it should be protected. Seen in this light, the history prong is mere surplusage.

Sunstein's theory supplies a reading of the history prong that is not redundant with the political powerlessness prong. It does so by emphasizing how the history prong asks the decisionmaker to look not just at what he sees, but also at the lens through which he sees it. Thus, a judge who sees that a group is not politically powerless is asked whether he might be unable to see empathy failure because of a mindset he has inherited. Conversely, a judge who sees a group that is politically powerless might be reminded by the fact that a history of discrimination does not exist that what he is seeing is not so great a harm, but a self-correcting vicissitude of the political process. In other words, while a finding that a group currently enjoys political power should make an historical inquiry irrelevant, one cannot make that finding in the absence of that historical inquiry.

93. See, e.g., High Tech Gays v. Defense Indus. Sec. Clearance Office, 895 F.2d 563, 573-74 (9th Cir. 1990) (finding that while gays have suffered a history of discrimination, they are not defined by an immutable characteristic and are not politically powerless); BenShalom v. Marsh, 881 F.2d 454, 465-66 (7th Cir. 1989) (finding in dicta that while gays have suffered a history of discrimination they are not politically powerless). Of course, this gives only weak support to the hypothesis, given that it is implicit in a three-prong test that solnething can satisfy prong one without satisfying prong two or prong three. The examples below, however, should indicate that the prongs are not as independent as they might seem. 
ples do exist. In Frontiero v. Richardson, the Court held that women suffered a history of discrimination and investigated the ways in which women were subordinated by men.94 It described the "attitude of 'romantic paternalism,' which, in practical effect, put women, not on a pedestal, but in a cage." 95 This exegesis under the history prong explicitly "trickled over" into the Court's subsequent analysis of the politicalpowerlessness prong. ${ }^{96}$ In dealing with the political-powerlessness prong, the Court had to overcome the presumption that women were not politically powerless because they constituted a majority of the population. The Court did so by noting that: "It is true, of course, that when viewed in the abstract, women do not constitute a small and powerless minority. Nevertheless, in part because of past discrimination, women are vastly underrepresented in this Nation's decisionmaking councils." ${ }^{77}$ The Court thus adverted to its previous analysis under the history prong to show that one test of political powerlessness would be more appropriate than another, thereby seriously affecting the ultimate determination. The three prongs may not be as independent as a "three-prong test" implies-the history prong sometimes may operate as an independent variable that shapes the other prongs. ${ }^{98}$

An inquiry into the history prong is thus clearly relevant, meriting an exploration of how that inquiry is conducted. When courts properly discuss this prong, they isolate two implicit components. First, courts consider whether the group asking for heightened scrutiny has encountered a history of discrimination similar to that encountered by an already protected group. Second, and tangentially, courts consider the particularities of the history of the group in question to isolate elements of oppres-

94. See 411 U.S. 677,684 (1973).

95. Id. In considering this history of discrimination, the Frontiero Court appeared to sound a warning note much like Stevens's admonition in Mathews that judges must be careful about replicating past discrimination. As evidence that it had been susceptible to discriminatory attitudes toward women in the past, the Court quoted Justice Bradley's statement that the " "paramount destiny and mission of woman are [sic] to fulfil the noble and benign offices of wife and mother. This is the law of the Creator.' " Id. at 685 (quoting Bradwell v. State, 83 U.S. (16 Wall.) 130, 141 (Bradley, J., concurring)). The Frontiero Court emphasized that "a distinguished Member of this Court was able to proclaim" these words a hundred years before its own decision, implying that if even a "distinguished" member of the Court was susceptible to such notions, present members should be vigilant about their own vulnerability to them. Id. at 684 .

96. While the prongs were not enumerated as such in the case, all three were deployed. See id. at 685-86.

97. Id. at 686 n.17 (emphasis added).

98. As I argue more fully below, see infra Part IV, a parallel trickle-over effect might occur in the gay context. When a court investigates the history of gay persecution, it will be more likely to see how the history of gays is a history of the closet. If a court understands how the closet inflects gay oppression, it will be more likely in turn to reject the standard tests for measuring political powerlessness. Just as the Court rejected the "headcount in the population" test for women to adopt the "representation in the Nation's decisionmaking councils" test, see Frontiero, 411 U.S. at 684 , a court that understood the closet might see that neither test adequately captures the political powerlessness of gays. 
sion that might not resonate with those of an already protected group. The two steps can thus be seen as separate, even conflicting, inquiries, the first protecting a group because of the way im which it resembles already protected groups, the second protecting it for ways in which it differs from those groups.

1. Step One: Inside the Discourse of Equivalents. - Under the first step, a group seeking protection is recognized as "satisfying" the prong if its history is sufficiently analogous to the history of a group that has already been accorded heightened scrutiny. ${ }^{99}$ These talismanic groups include those based on race, ${ }^{100}$ national origin, ${ }^{101}$ gender, ${ }^{102}$ alienage, ${ }^{103}$ and illegitimacy. ${ }^{104}$ Thus, in Frontiero, the Court used the observation that "throughout much of the 19th century the position of women in our society was, in many respects, comparable to that of blacks under the preCivil War slave codes," 105 as a predicate for finding that women had suffered a significant history of discrimination. Employing the same standard to reach a different result, the Court held in Massachusetts Board of Retirement $v$. Murgia that "[w] hile the treatment of the aged in this Nation has not been wholly free of discrimination, such persons, unlike, say, those who have been discriminated against on the basis of race or national origin, have not experienced a 'history of purposeful unequal treatment." "106

Analyzing the debate surrounding gay civil-rights legislation, Jane Schacter has baptized this framework as the "discourse of equivalents." According to Schacter, this framework asks whether gay men and lesbians sufficiently resemble other traditionally protected groups, thus using current "civil rights laws as the normative baseline against which the gay civil rights claim is tested to determine whether the fit between established and aspiring law is sufficiently close to confer legitimacy." 107 While Schacter is commenting about legislation, the discourse of equivalents has a similar hold in Equal Protection case law. Indeed, it may have a stronger hold in case law because of the countermajoritarian nature of

99. Savor the ironies. First, instead of demanding equal treatment with the privileged, disempowered minorities under the discourse of equivalents ask for equal treatment with other oppressed groups. Second, the Equal Protection Clause, which can be seen as iconoclastic in the sense that it inverts the law's sacralization of history, must nonetheless justify that iconoclasm by adverting to comparable historical examples of iconoclasm.

100. See, e.g., Korematsu v. United States, 323 U.S. 214, 216 (1944).

101. See, e.g., Hernandez v. Texas, 347 U.S. 475,479 (1954).

102. See, e.g., Craig v. Boren, 429 U.S. 190, 197 (1976).

103. See, e.g., Graham v. Richardson, 403 U.S. 365, 372 (1971).

104. See, e.g., Mathews v. Lucas, 427 U.S. 495, 504 (1976).

105. Frontiero v. Richardson, 411 U.S. 677, 685 (1975).

106. 427 U.S. 307, 313 (1976). Similarly, in Mathews, the Court noted that discrimination against the illegitimate "has never approached. . . the historic legal and political discrimination against women and Negroes." Mathews, 427 U.S. at 506.

107. Jane S. Schacter, The Gay Civil Rights Debate in the States: Decoding the Discourse of Equivalents, 29 Harv. C.R.-C.L. L. Rev. 283, 285 (1994). 
judging. Definitionally, a court would be asked to break from the discourse of equivalents only where the legislature had not already acted sufficiently to protect a particular group, and courts are highly reluctant to second-guess the legislature in such a scenario. ${ }^{108}$ Furthermore, within the case law, the discourse has its strongest hold in the arena of constitutional adjudication, because of the difficulty a legislature has in overturning a court's decision. We thus can expect the discourse of equivalents under Equal Protection jurisprudence to be highly restrictive.

The question then arises of how the history of discrimination suffered by gays fares under that discourse. That history has been challenged as less severe than that experienced by racial minorities or women in at least three ways. First, sex (and race) are seen to be immutable, while sexual orientation is seen as chosen. ${ }^{109}$ As noted below, immutable characteristics are seen as increasing the severity of discrimination (insofar as persons cannot evade that discrimination by changing those characteristics) and also as calling into question the rationality of the discrimination itself (insofar as persons cannot be held culpable for what they cannot choose). ${ }^{110}$ Second, it is asserted that as gays have never been denied the vote, they are presumptively less vulnerable to the political process than women or blacks. ${ }^{111}$ Third, it is argued that gays have discretion over the expression of their identity. Thus, even if homosexuality were immutable, gays could still evade many forms of discrimination by masking that trait. In the economy of the Equal Protection Clause, visibility counts toward a history of discrimination, while invisibility counts against it. For example, in Frontiero, the Court noted that "it can hardly be doubted that, in part because of the high visibility of the sex characteristic, women still face pervasive, although at times more subtle, discrimination." 12 Conversely, in Mathews, the Court hypothesized that the history of discrimination suffered by the illegitimate did not rise to the level of that suffered by women or blacks "perhaps in part because illegitimacy does not carry an obvious badge."113

These differences provide a powerful barrier to arguments tying the history of discrimination suffered by gays with that suffered by other already protected groups. That courts to reach the issue have deemed gays to have suffered a history of discrimination is not to the contrary. These

108. For the genesis of the modern debate on the countermajoritarian difficulty, see Alexander M. Bickel, The Least Dangerous Branch: The Supreme Court at the Bar of Politics 16-23 (2d ed. 1986).

109. See Neil L. Glazer, Straight Talk About Homosexuality, Harv. L. Rec., Mar. 5, 1993, at 15 .

110. For an extended discussion of imutability, see infra Part IV.

111. Schacter notes that "a video entitled 'Gay Rights/Special Rights,' produced by a conservative group called the Traditional Values Coalition and aimed at minority audiences, features a screen with the heading 'Ever denied the right to vote?' and the answers 'Homosexuals: No;' 'African Americans: Yes.' " Schacter, supra note 107, at 292.

112. Frontiero v. Richardson, 411 U.S. 677, 686 (1973) (footnote omitted).

113. Mathews v. Lucas, 427 U.S. 495, 506 (1976). 
differences may be the subtext for courts deciding that Bowers pre-empts the heightened scrutiny inquiry. Moreover, even for the courts that do engage in the inquiry, these barriers may inhibit a deeper inquiry into the history of discrimination against gays that could trickle over to other prongs.

2. Step Two: Outside the Discourse of Equivalents. - An alternative approach to the inquiry into a group's history of discrimination points out the flaws of the discourse of equivalents. Schacter challenges this discourse because it implies that "civil rights protection can be tested and resolved against a stable and historically constant conceptual template" and thereby transforms "anti-discrimination law into a bulwark for preserving the status quo."114 As Schacter notes:

Discrimination against gay men and lesbians as a group has not mirrored the discrimination suffered by other groups protected under civil rights laws. The experiences of these protected groups have themselves, however, been far from identical. For example, the enduring legacy of slavery makes discrimination against African Americans distinct from the pervasive historic subordination of Native Americans or the social and economic subordination of women. None of these experiences replicates the others. And none replicates the social history of homosexuality. ${ }^{115}$

These criticisms, clearly applicable to Equal Protection jurisprudence, point out that a legal order that counteracts discrimination against gays only to the extent it resonates with the discrimination of an already protected group will necessarily be underinclusive. ${ }^{116}$

114. Schacter, supra note 107 , at 297.

115. Id.

116. Andrew Koppelman's argument that discrimination against gays is a kind of sex discrimination is particularly susceptible to this charge because it recognizes discrimination against gays only to the extent that this discrimination maps onto discrimination against women. Koppelman recognizes this, quoting Jonathan Goldberg's criticism that "[b]y collapsing questions of sexuality into the 'more important' realms of gender, homosexuality is allowed salience insofar as it seems assimilable to heterosexuality, insofar as same-sex relations are taken to be no different from cross-sex ones." Koppelman, supra note 2, at 202 n.16 (quoting Jonathan Goldberg, Sodometries: Renaissance Texts, Modern Sexualities 15 (1992)). Koppelman responds that " $[t]$ he point of the present argument is, however, not 'to seek to hierarchize oppressions,' but to map the ways in which they are related." Id. (quoting Goldberg, supra, at 14). This response is too easy. Equal Protection jurisprudence markedly deploys a hierarchy of oppressions. Only a small number of groups-those who have suffered enough to meet the requirements of the history prong-will be accorded protection under the Clause. While Koppelman doubtless does not "seek to hierarchize oppressions," that will be the likely effect of his analysis. If courts recognize discrimination against gays as sex discrimination but not as discrimination against gays simpliciter, the current hierarchy of sex over sexual orientation as a category will endure. Arguing within the status quo has the benefit of persuading those averse to change but the burden of entrenching their potentially incorrect assumptions. 
The second step of the history prong, while much less prominent than the first, plays some role in mitigating this problem by investigating differences between historical oppressions. If a group's history of discrimination diverges from that experienced by an already protected group, the divergence counts against it, but its effects may be overcome if the group can show that this difference is nonetheless oppressive. Thus, in Frontiero, the Court noted that women should be granted heightened scrutiny because they had suffered from "romantic paternalism."117 Such romantic paternalism distinguished women from blacks-while blacks have been subjected to paternalism, it is doubtful that anyone would characterize it as putting them "on a pedestal."118 In the case of women, the Court was willing to grant protection not in spite of, but because of, a characteristic that lay outside the discourse of equivalents.

The difficulty of arguing outside the discourse of equivalents is that courts impose a much higher standard before recoguizing particular characteristics as warranting solicitude. Every new characteristic the courts recognize as warranting greater protection threatens to open the floodgates to a new wave of groups asking for protection based on that characteristic. Recognizing this, courts understandably are loath to expand their portfolio of relevant characteristics. In City of Cleburne, Texas $v$. Cleburne Living Center, Inc., the Supreme Court noted its reluctance to give heightened scrutiny to the mentally retarded in terms reflecting its restrictive animus:

[I]f the large and amorphous class of the mentally retarded were deemed quasi-suspect for the reasons given by the Court of Appeals, it would be difficult to find a principled way to distinguish a variety of other groups who have perhaps immutable disabilities setting them off from others, who cannot themselves mandate the desired legislative responses, and who can claim some degree of prejudice from at least part of the public at large. One need mention in this respect only the aging, the disabled, the mentally ill, and the infirm. We are reluctant to set out on that course, and decline to do so. ${ }^{119}$

The Court anticipates the tying arguments that will be made if it deems another group, and therefore another set of characteristics, worthy of protection. It states its reluctance to recoguize new classes in no uncertain terms. As a result, gays face a formidable hurdle in attempting to garner protection based on a characteristic that falls outside the discourse of equivalents.

117. Frontiero, 411 U.S. at 684.

118. Id. The "romantic paternalism" argument contrasts with the "numerosity" argument, in which the Court noted that women were not a minority in the population. Both arguments revealed that women were different from blacks, but while the numerosity argument cut against granting them protection, the "romantic paternalism" argument cut in favor of granting that protection.

119. 473 U.S. 432, 445-46 (1985). 
In short, courts engage in a two-step inquiry under the history prong-first inquiring after a group's similarity to an already protected group and then inquiring after the group's difference from such a group. Both steps are in keeping with the Clause's spirit of empathy. By forcing a court to consider the analogy between the suffering of a certain group and another protected group, the first step makes the court consider whether its sympathies, already extended to one group, can logically be withheld from another. By pushing a court to consider the differences between the oppression of the group asking for protection and other groups, the second step encourages the court to consider the particularities of that oppression. This ensures that a group that cannot "tie" its claims to a pre-existing sympathy will not be excluded solely on that basis. Gays seem to face an impasse under both steps of the history prong. Insofar as they choose to argue within the discourse of equivalents, they must confront aspects of their history that do not resonate with those of already protected groups; insofar as they choose to argue outside the discourse of equivalents, they, like all previously unrecognized groups, face high barriers to getting particular characteristics recognized as warranting solicitude. The pink triangle, however, partially resolves both impasses.

\section{B. The Pink Triangle}

As recounted in my initial anecdote, "[ $t]$ he pink triangle was used by the Nazis during the Holocaust to designate homosexuals." 120 It was one of many symbols used in creating a taxonomy of "contragenics": red patches for political prisoners, ${ }^{121}$ green triangles for criminals, ${ }^{122}$ black triangles for asocials, ${ }^{123}$ and yellow stars for Jews. ${ }^{124}$ The pink triangle thus implicitly links gay oppression to the oppression of other minorities-particularly Jews, who were the most numerous and prominent victims of the Holocaust.

To understand the importance of the choice of the triangle as an emblem of the gay movement, we must understand the costs of that choice. While the more conventional strategy may be to link the oppressed group to a symbol that has positive connotations, ${ }^{125}$ the triangle appropriates and recasts a symbol of victimhood. The choice was an active one, for the movement rejected the alternative of the Greek

120. See supra text accompanying note 1 .

121. See Richard Plant, The Pink Triangle: The Nazi War Against Homosexuals 14 (1986).

122. See id. at 160.

123. See id.

124. See Gore Vidal, Pink Triangle and Yellow Star, in Pink Triangle and Yellow Star and Other Essays 1976-82 at 167, 170 (1982).

125. The rainbow flag is an example of this strategy. See Deb Price, Rainbow Flag Is Symbol of a United Gay People, Star Trib., Apr. 19, 1995, at $4 \mathrm{E}$ (describing positive connotations of rainbow flag and contrasting these with negative connotations of pink triangle). 
lambda, ${ }^{126}$ which evokes the more tolerant Hellenic attitudes toward homosexuality. ${ }^{127}$ The movement's choice to associate itself with the nadir rather than with the zenith of historical toleration for gays has been hotly criticized. Stuart Marshall states: “I've spoken with people who were forced to wear the pink triangle in concentration camps, and they were horrified by its contemporary use by the gay movement. The memories they associate with the image are unspeakable."128

Yet discarding the pink triangle because the symbol cannot be cut free of its initial use misses the point. As a symbol, the pink triangle is undeniably unstable, given that its pro-gay use is constantly haunted by the memory of its anti-gay deployment. But part of the power of the pink triangle to represent the gay-rights movement stems precisely from this instability. Indeed, it may be less accurate to say that the symbol is unstable than to say that it incorporates instability as part of its meaning. The symbol aptly reflects the history of rights for homosexuals, in which tolerance has waxed and waned. 129

As a symbol of instability, the pink triangle may galvanize pro-gay sentiment on the part of both those initially sympathetic and those unsympathetic to the movement. For gay sympathizers, the pink triangle serves as a minatory symbol against complacency. Even Marshall, who laments the use of the symbol at a time when the gay-rights movement is perhaps experiencing its moment of greatest optimism, also recognizes that the Weimar Republic that preceded the Third Reich was a period of relative tolerance for homosexuals. ${ }^{130}$ The pink triangle reminds pro-gay sympathizers that its original usage could be resuscitated at any time; indeed, some argue that no resuscitation is necessary. ${ }^{131}$ The symbol works on those not already sympathetic to the gay rights movement as well. By invoking the Holocaust, the triangle evokes a raft of associations that has

126. See Stuart Marshall, The Contemporary Political Use of Gay History: The Third Reich, in How Do I Look? 65, 68 (Bad Object-Choices ed., 1991).

127. For an account of these more tolerant attitudes, see generally Martha $\mathrm{C}$. Nussbaum, Platonic Love and Colorado Law: The Relevance of Ancient Greek Norms to Modern Sexual Controversies, 80 Va. L. Rev. 1515 (1994) and sources cited therein.

128. Marshall, supra note 126, at 91. For first-person accounts of the treatment of homosexuals in the concentration camps, see, e.g., Pierre Seel, I, Pierre Seel, Deported Homosexual: A Memoir of Nazi Terror (Joachim Neugroschel trans., 1995) (memoir of gay survivor relating his experiences in Schirmeck-Vorbrüch concentration camp); Plant, supra note 121 (various accounts by gay survivors of experiences in camps).

129. The Nazis themselves attributed a perceived rise in homosexuality to the more permissive preceding era:

When the Nazis came to power ... they raised the estimate [of homosexuallyinclined men in Germany] to 2 million men, 10 percent of the male population. The Nazis called these new figures a "frightful legacy from the liberalistic period" which had to be eliminated. Homosexuals were therefore branded as enemies of the state.

Vern L. Bullough, Homosexuality: A History 94 (1979) (footnote omitted).

130. See Marshall, supra note 126 , at $67,79$.

131. See Eve K. Sedgwick, The Epistemology of the Closet 129 (1990) (characterizing the American response to AIDS as enacting a genocidal fantasy of a world without gays). 
made its way into the cultural consciousness of most Americans through the history of the Jews. By drawing a nexus between the persecution of homosexuals and the persecution of Jews, the symbol invites homophobes to ask whether they occupy the position in relation to the homosexual that the Nazis occupied in relation to the Jew.

While the pink triangle thus makes an evocative pro-gay appeal on a visceral level, it also provides a rational contribution to the history prong of the Equal Protection test. It responds to the first step, which requires comparison to groups that have received protection, by pointing out that the grounds raised for distinguishing gays from blacks or women-mutability, the historical right to vote, and invisibility-do not distinguish them from Jews. The pink triangle also engages the second step, which examines differences between historical oppressions, to highlight one aspect of the history of gays that makes them unlike other groups, but which contributes to their oppression-namely the distinctive invisibility of that history.

1. Step One. - The pink triangle provides an answer to the impasse the pro-gay argument encounters under the first step of the history prong by linking gays to Jews. While the Supreme Court has never held that religious groups are protected as a suspect class under the Equal Protection Clause, there is both legislative and judicial evidence that such groups are deemed worthy of protection. In the legislative context, religion is typically equated (via a discourse of equivalents) with race and gender. For example, Title VII of the 1964 Civil Rights Act prohibits employment discrimination on the basis of religion as well as on the basis of race, color, sex, and national origin. ${ }^{132}$ In the Equal Protection context, the Supreme Court has noted in dicta that heightened scrutiny applies when "inherently suspect distinctions such as race, religion, or alienage' " are at issue. ${ }^{133}$ The fact that Jews (and other religious groups) have not been protected under the Equal Protection Clause may stand for nothing more than the fact that protections guaranteed religious groups under the First Amendment pre-empt that inquiry. ${ }^{134}$ Any link that gays can make with Jews will thus reinforce the claim to protection under the first prong.

That link is easily made. Jews, like gays, have none of the three characteristics commonly used to distinguish gays from blacks or women. First, many elements of Jewish identity are not biologically imunutable,

132. See 42 U.S.C. $\$ 2000$ e-2 (1991). Notably, efforts to amend Title VII to include sexual orientation as a protected category have failed. See, e.g., Civil Rights Act Amendments of 1981: Hearing on H.R. 1454 Before the Subcomin. on Employment Opportunities of the House Coinm. on Education and Labor, 97th Cong., 2d Sess. 1-2 (1982) (statement of Congressman Ted Weiss).

133. Metropolitan Life Ins. Co. v. Ward, 470 U.S. 869, 885 (1985) (O'Connor, J., dissenting) (quoting New Orleans v. Dukes, 427 U.S. 297, 303 (1976)) (emphasis added).

134. See generally Benjamin H. Barton, Note, Religion-Based Peremptory Challenges After Batson v. Kentucky and J.E.B. v. Alabama: An Equal Protection and First Amendment Analysis, 94 Mich. L. Rev. 191 (1995). 
but instead are the product of individual choice. ${ }^{135}$ Second, Jews were not denied the right to vote in the United States, revealing that political persecution is not limited to formally disenfranchised groups. Finally, Jews, like gays, often do not carry a visible badge of their identity. ${ }^{136}$ As Sedgwick notes, "[e]thnic/cultural/religious oppressions such as antiSemitism are more analogous in that the stigmatized individual has at least notionally some discretion-although, importantly, it is never to be taken for granted how much-over other people's knowledge of her or his membership in the group."197

These similarities allow gays to draw on the greater cultural literacy that people have about Jews in order to provide access to the experience of gay oppression. The intellectual link between the invisibility of gays and the invisibility of Jews, for example, may be further exfoliated by adverting to the more robust cultural mythology surrounding Judaism. Sedgwick does precisely this by juxtaposing Jean Racine's account of the Biblical Purim story against the hypothetical story of a gay clerk in the chambers of a Supreme Court Justice who does not come out to the Justice prior to Bowers. ${ }^{138}$ The Purim story is Holocaustal: King Assuérus is prompted by his advisor Aman to attempt to purge the world of Jews. ${ }^{139}$ The King's wife Esther has hidden the fact that she is Jewish from her husband, but discloses that fact in an attempt to avert the genocide. By doing so, she forces her husband to weigh the intimate against the Holocaustal; he almost instantly chooses the former. With that small, personal disclosure, she is able to persuade her husband to save not only herself, but her entire people. ${ }^{140}$ Sedgwick relates this myth to the gay context:

It would not be hard to imagine a version of Esther set in the Supreme Court in the days immediately before the decision in Bowers v. Hardwick. Cast as the ingenue in the title role a hypothetical closeted gay clerk, as Assuérus a hypothetical Justice of the same gender who is about to make a majority of five in sup-

135. See Suzanna Sherry, Selective Judicial Activism in the Equal Protection Context: Democracy, Distrust, and Deconstruction, 73 Geo. L.J. 89, 122-23 (1984).

136. I refer here to physical traits-first and last names, of course, are often used as visible badges of Jewish identity. See id.

137. Sedgwick, supra note 131 , at 75 . Gays share these attributes with religious groups generally. See Lisa Duggan, Queering the State, in Sex Wars, supra note 8, at 189-90. However, as noted below, the nexus between gays and Jews is particularly evocative.

138. See Sedgwick, supra note 131, at 76-79 (discussing Jean Racine, Esther (H.R. Roach ed., 1949)).

139. See id. at 76. For purposes of consistency with the quotation below, I retain Racine's spellings of "Assuérus" and "Aman" instead of the conventional English spellings "Ahasuerus" and "Haman."

140. See id. To these points, add that Esther is terrified to come out; that she fears for her life and has all the Jews of the city fast for three days in an appeal to God that she be spared when she approaches the King; and that, in recognition of this, Purim is today celebrated as a mask-and-disguise festival. 
port of the Georgia law. The Justice has grown fond of the clerk, oddly fonder than s/he is used to being of clerks . . . ${ }^{141}$ Sedgwick's sentence trails off here, but we know how the story ends. What gives this comparison its plangency is that the Esther story underscores both the incomparable personal risk, as well as the enormous transformative potential, that coming out entails for many gay persons.

Although the holocaust referred to here is not the Nazi Holocaust, the pink triangle illuminates this comparison. To coinpare Esther to the gay clerk is to compare the averted extermination of the Jews to the verdict in Bowers, threats not remotely comparable. Yet this analogy is rendered less combustible by the associational axis already created by the pink triangle, which reminds us that if gays were not threatened by that holocaust, they were implicated in the other one alongside Jews.

While the gay-Jewish comparison gives a better response to the impasse under the first step of the history prong, it is not a perfect one. The analogy between gays and Jews may be closer than that between gays and blacks or gays and women, but it still inevitably engenders resistance. As Sedgwick notes, " $[t]$ here is another whole family of reasons why too long a lingering on moments of Esther-style avowal must inisrepresent the truths of homophobic oppression; these go back to the important differences between Jewish ... . and gay identity and oppression." 142 That resis-

141. Id. at 76-77. Perhaps one reason why this scenario is not hard to imagine is that it essentially happened. The true story of the gay clerk in the Supreme Court who was in the critical chambers in the critical year is well-known in gay communities. It has tended, however, to remain oral, rather than written, history; in casting the account as a hypothetical, Sedgwick was probably protecting the privacy of the gay clerk from the greater exposure that occurs when stories are fixed in print. I realize that I may be accused of violating that privacy in typing these words, but the account has since been published in (among other places) John Jeffries's biography of Lewis Powell. See John C. Jeffries, Jr., Justice Lewis F. Powell, Jr. 511-30 (1994). The Justice in question was Lewis Powell, who was the swing vote in the case, and who said to one of his clerks that "'I don't believe I've ever met a homosexual," " without knowing that the person he was addressing was gay. ld. at 521 (quoting Justice Powell). Without naming the clerk, Jeffries reveals most parts of Sedgwick's "hypothetical" as truth:

Uncharacteristically, [just hefore oral argument] Powell had still not decided how

he would vote. In great distress, the [gay] clerk debated whether to tell Powell of his sexual orientation. Perhaps if Powell could put a familiar face to these incomprehensible urges, they would seem less bizarre and threatening. He came to the edge of an outright declaration but ultimately drew back, settling for a "very emotional" speech urging Powell to support sexual freedom as a fundamental right. "The right to love the person of my choice," he argued, "would be far more important to me than the right to vote in elections." "That may be," Powell answered, "but that doesn't mean it's in the Constitution."

Id. at 521-22. What is startling about this account is that Powell's gay clerk made his own presence hypothetical when he used the words "would be," rather than "is." Powell went on to join Justice White's opinion, providing the crucial fifth vote that made it the majority opinion. Id. at 525.

142. Sedgwick, supra note 131 , at 78 . This family of reasons includes the following: (1) "there is no suggestion that ... [Esther's] identity might be a debatable, a porous, a mutable fact about her"; (2) "Esther expects Assuérus to be altogether surprised by her 
tance is also felt by those who are not pro-gay. ${ }^{143}$

Gays may insist on differences between themselves and other minorities with ferocity precisely because of their ability to be rendered invisible and to be subsumed within their other affiliations. Distorting gay identity to make it look like that of blacks or women or Jews resonates with the phase prior to coming out in which gays distort their identity to look like straights. If gays are going to pretend to be something they are not, the thought goes, why not pretend to good purpose and pretend to be heterosexual? ${ }^{144}$ While the pink triangle responds to the major problems of the first step, these responses do not assuage the fear that to argue within the discourse of equivalents only announces a capture by it. Yet the genius of the pink triangle is that it responds, albeit in a limited way, to this critique as well.

2. Step Two. - While the pink triangle evokes the similarity between gay history and Jewish history in one sense, it simultaneously emphasizes a difference between them-their comparative visibility. Although gays and Jews are both comparably invisible as individuals, they are not both comparably invisible as groups. The choice of the pink triangle as an emblem of the gay-rights movement itself underscores the distinctive invisibility of gay history. Not only is the triangle necessary to locate a pe-

self-disclosure, and he is"; (3) "Esther worries that her revelation might destroy her or fail to help her people, but it does not seem to her likely to damage Assuérus, and it does not indeed damage him"; (4) "The inert substance of Assuérus seems to have no definitional involvement with the religious/ethnic identity of Esther"; (5) "There is no suggestion that Assuérus might himself be a Jew in disguise"; (6) "Esther knows who her people are and has an immediate answerability to them,"; and (7) "Esther's avowal occurs within and perpetuates a coherent system of gender subordination." Id. at 79-81 (emphasis omitted).

143. As Gore Vidal notes:

I was present when Christopher Isherwood tried to make [the analogy between gays and Jews] to a young Jewish movie producer. "After all," said Isherwood, "Hitler killed six hundred thousand homosexuals." The young man was not impressed. "But Hitler killed six million Jews," he said sternly. "What are you?" asked Isherwood. "In real estate?"

Vidal, supra note 124, at 170 . Comparing gays to blacks, women, or Jews will always encounter resistance from persons who think that the analogy denigrates or mischaracterizes the history of the latter groups. Such resistance is not necessarily homophobic. One form of this criticism, for example, points out that the suffering of the already-protected group is being used in order to get more protection for another group, rather than being recognized in its own right. It is indeed hard not to wonder when gays (or any other group) invoke an analogy to another group whether their sympathies for the suffering of that group extend beyond that group's use to them. If we as gays are asking that other people empathize by comparing our suffering to that experienced by blacks, we might do well to think about what kind of understanding we ourselves have of the experience on which that analogy is based. But it is important to remember that gays themselves are unlikely to enjoy this process. To use another group's suffering to secure one's own rights implies a benefit arising from that group's suffering, which, absent schadenfreude, is a position most persons are unlikely to relish. The discourse of equivalents places both protected and unprotected groups in an unsavory position.

144. See Martin Sherman, Bent 28-36, 38-41 (1979) (play depicting gay non-Jew who successfully passes as straight Jew). 
riod in that history that would otherwise remain uncharted, but that symbol is often only understood through its connection to the yellow star. Thus, while the pink triangle appears to stress its similarity to the yellow star, it simultaneously relies on the difference between the two symbolsnamely the greater cultural understanding of the suffering underlying the yellow star-to achieve its potency. We see this dynamic at work in Sedgwick's comparison-the centrality of the Purim story, and Sedgwick's ability to count on its cultural accessibility, highlight the absence of gay mythologies on which the agon of the clerk's story could intelligibly be mapped.

The pink triangle thus stands not only as an emblem of the homosexual, but also as an emblem of the invisibility of gay history. The triangle, accompanied by the slogan SILENCE = DEATH, constitutes the most famous graphic to arise out of the AIDS crisis. ${ }^{145}$ The emblem was created by the Silence $=$ Death Project, six gay men who later joined the ACT UP organization. ${ }^{146}$ In describing why they chose the symbol, a member of the project noted:

Our emblem's significance depends on foreknowledge of the use of the pink triangle as the marker of gay men in Nazi concentration camps, [and] its appropriation by the gay movement to remember a suppressed history of our oppression . . . . SILENCE = DEATH declares that silence about the oppression and annihilation of gay people, then and now, must be broken as a matter of our survival. 147

The AIDS symbol, which explicitly builds on the pink triangle, rests its force on the ability of the triangle to act as a public mnemonic for an otherwise occluded history. In my initial anecdote, what gave the judge's ignorance of the symbol its poignancy is that he had not heard of the symbol that most pointedly represented the gay will to be heard.

The distinctive invisibility of the gay-rights movement is related to the invisibility of gay individuals. ${ }^{148}$ Contrast, for example, the sixties slogan "Black is Beautiful," 149 with the nineties slogan "We're here, we're

145. See Rob Baker, The Art of AIDS 141 (1994).

146. See id. ACT UP, or the AIDS Coalition to Unleash Power, is "a diverse, nonpartisan group united in anger and committed to direct action to end the AIDS crisis." Crimp \& Rolston, supra note 78, at 13.

147. Id. at 14.

148. The invisibility of individual gays is better captured through the symbol of the closet. See infra Part III. The two invisibilities (of individuals and of the group) are related yet distinct. Individual invisibility deeply abets group invisibility, as if to breathe new sociological life into the discredited biological maxim that ontogeny recapitulates phylogeny. Yet they are also distinct, as many individually "out" gay scholars have found in their attempts to recuperate a history that remains stubbornly closeted. See Lisa Duggan, History's Gay Ghetto: The Contradictions of Growth in Lesbian and Gay History, in Sex Warș, supra note 8, at 144-145. I focus here on group invisibility.

149. See Renee Graham, 'Black Is': political, personal, powerful, Boston Globe, Feb. 26,1996 , at 36 (discussing the history of the slogan). 
queer, get used to it!"150 The slogans come from the civil rights movements for African-Americans and gays, respectively. The contrast, however, lies in the fact that African-Americans are trying to reshape perceptions of who they are while gays are trying to assert their mere existence. While other slogans, such as "Gay is Good" resonate with "Black is Beautiful," 151 the "We're here" slogan indicates a consciousness that before gays can convince people of what they are, they must convince people that they are..$^{152}$

This raises the question of whether gay invisibility meets the stringent standard that courts apply to isolate new historical debilities. An affirmative response may rely on the fact that judges have been deeply complicit in producing gay invisibility, so they should be hyper-aware of their potential continued complicity in it. Again, given that the purpose of the Equal Protection Clause is to preclude empathy failure, it is relevant that one of the attributes of the group under investigation is a chronic inability to make its oppression visible.

Insofar as judges share society's blindness toward the gay community, of course, they will be difficult to persuade. We want to think that those engaged in privileged discourse, here judicial discourse, should know basic facts about the persons about whom they rule. But should they? Sedgwick argues that they "should" not, given that their ignorance has been as carefully cultivated as our knowledge through the exercise of what she calls the epistemological privilege of unknowing:

150. See Bruce Bawer, Notes on Stonewall, The New Republic, June 13, 1994, at 24, 26 (discussing the use of the slogan in the gay rights movement).

151. Indeed, "Gay is Good" explicitly drew on "Black is Beautiful." See Larry Gross, Contested Closets: The Politics and Ethics of Outing 20 (1993); see also Gabriel Rotello, Stonewall Goes Uptown to 42d Street, Newsday, Aug. 4, 1994, at A38 (noting resonance between two slogans).

152. This is not to say that other minorities are not made to feel as if they do not exist. Harlon Dalton's discussion of what he calls "e-racing," is one of the narratives that makes such an assercion impossible:

On occasion, I have been in the company of White folk who momentarily forgot that I was present, or who were temporarily blind to "what" I am. It is as if I had been transformed into a fly on the wall. "If a White person had done that, he would have been out on his ear!" "They have no respect for family." "Did you hear the one about ... ?" Suddenly, the conversation screeches to a halt and everyone freezes. Apparently, I have become visible again. Faces redden, and an effort is made to smooth things over.

Farlon L. Dalton, Racial Healing 71 (1995). The account trenchantly shows that one need not be physically invisible to be socially invisible. Even if one cannot "pass" in the crude sense of not giving immediate proof of one's identity, one can have that identity ignored and despoiled. Yet the narrative also illuminates what I see as a crucial difference between the context of race and sexual orientation, captured by the evocative word "e-raced." Erasure implies a prior text, and that text is Dalton's race, of which he has been denuded. Something existed that was obliterated. In contrast, it is harder to think about erasure in the gay context because it is harder to conceive of a gay text. The page of gay identity is not a palimpsest but a tabula rasa. 
Knowledge is not itself power, although it is the magnetic field of power. Ignorance and opacity collude or compete with it in mobilizing the flows of energy, desire, goods, meanings, persons. If M. Mitterrand knows English but Mr. Reagan lacks French, it is the urbane M. Mitterrand who must negotiate in an acquired tongue, the ignorant Mr. Reagan who may dilate in his native one. Or in the interactive speech model by which ... "the standard ... meaning can be thought of as what is recognizable solely on the basis of interlocutors' mutual knowledge of established practices of interpretation," it is the interlocutor who has or pretends to have the less broadly knowledgeable understanding of interpretive practice who will define the terms of the exchange. So, for instance, because "men, with superior extralinguistic resources and privileged discourse positions, are often less likely to treat perspectives different from their own as mutually available for communication," their attitudes are "thus more likely to leave a lasting imprint on the common semantic stock than women's." 153

Sedgwick uses the aptly protean phrase "privilege of unknowing" in a doubled sense-privilege permits ignorance, and ignorance entrenches privilege. The two senses create a feedback loop. Because the powerful have power, one must respect their ignorance and reduce one's speech to the lowest common denominator one shares with one's more powerful listeners if one hopes to persuade them. By watering down one's speech, however, one further entrenches the privilege that motivated that discursive strategy.

Under this formulation, homosexuality is regulated through a discourse of ignorance by regulators who do not need to understand it. This can be seen in the way homosexuality often is framed through preterition: that is, the mention of a term only to dismiss it. As noted by a typical legal encyclopedia:

The terms of many criminal sodomy statutes reflect the legislators' reluctance to set out in detail the elements of sodomy because of its loathsome nature. Instead, the statutes simply provide for the punishment of any person who commits "sodomy or the crime against nature," or "the abominable and detestable crime against nature," or designate the offense of sodomy simply as "sodomy" or "the crime against nature" or by similar euphemisms. ${ }^{154}$

Or, as Sedgwick puts it more colorfully:

Unspeakable, Unmentionable, nefandam libidinem, "that sin which should be neither named nor committed," the "detestable and abommable sin, amongst Christians not to be named," "Whose vice in special, if I would declare, It were enough for to perturb the air." "Things fearful to name," "the obscene sound

153. Eve $\mathrm{K}$ Sedgwick, Privilege of Unknowing: Diderot's The Nun, reprinted in Tendencies 23, 23 (1993) (citations omitted).

154. 70A Am. Jur. 2d Sodomy $\$ 3$ (1987) (citations omitted). 
of the unbeseeming words," "A sin so odious that the fame of it / Will fright the damned in the darksome pit," "the love that dare not speak its name"-such were the speakable nonmedical terms, in Christian tradition, for the homosexual possibility for men. ${ }^{155}$

What emerges from these formulations is that the loathsomeness of the crime prevents it from being named, much less discussed, with precision. This is an infelicitous combination, given that it might result in serious penalties for inchoate transgressions. ${ }^{156}$

Bowers exemplifies the epistemological privilege of unknowing, both in the majority opinion, which upheld the Georgia sodomy law, and, less intuitively, in the dissent, which would have struck down the law. The majority's privilege of unknowing was exercised in part through simple preterition. Its opinion noted that: "Blackstone described 'the infamous crime against nature' as an offense of 'deeper malignity' than rape, a heinous act 'the very mention of which is a disgrace to human nature,' and 'a crime not fit to be named.' "157 For the most part, however, the majority's privilege was exercised in a more sophisticated form of unknowing. The majority did not pass over the notion of homosexuality, but expatiated on the obviousness of its immorality and criminality, calling the claim that there is a right in this nation's history and traditions to engage in sodomy "facetious." 158 Even Justice Powell, who later stated that he

155. Sedgwick, supra note 131 , at 202-03.

156. The combination also begins to reveal the power of ignorance. In the same way that knowledge figures itself against the ground of ignorance, the named poses itself against the unnameable. This is unsurprising, because naming is a kind of knowledge, the redemption of a local knowable from the global unknown. Conventionally, just as knowledge is assumed to be power, the ability to name implies power as well; think, for example, of Adam naming the animals. Genesis 2:19-20. Yet the privilege of unknowing manifests its counterintuitive force in these preteritive formulations of sodomy insofar as the regulator's confession that an object cannot be named enhances rather than diminishes his power over it. In stating that they could not name homosexuality, those engaged in these preteritive acts were not stating that they could not control it. They did and do-gays in America have been "condemned to death by choking, burning and drowning; ... executed, [castrated], jailed, pilloried, fined, court-martialed, prostituted, fired, framed, blackmailed, disinherited, [lobotomized, shock-treated, psychoanalyzed and] declared insane, driven to insanity, to suicide, murder, and self-hate, witch-hunted, entrapped, stereotyped, mocked, insulted, isolated . . . castigated . . . despised [and degraded]." Thomas, supra note 2, at 1462 (quoting Jonathan Katz, Gay American History: Lesbians and Gay Men in the U.S.A. 11 (1976)) (alterations in original); see also Andrew Sullivan, Virtually Normal 22 (1995) (discussing sanctions against homosexuality). Indeed, the endless mill of speech about homosexuality's unnameable nature may have insulated that regulation from resistance, because that regulation found justification in the putative consensus of silence.

157. Bowers v. Hardwick, 478 U.S. 186, 197 (1986) (quoting 4 William Blackstone, Commentaries *215).

158. Id. at 194. 
may have made an error in casting the deciding vote, was at pains to say how little that insight affected him. 159

The Bowers concurrence also shows that those who control discourse are not necessarily those who know it best. Consider, for example, Chief Justice Burger's claim that protection for sodomy flouted "millennia of moral teaching." 160 Notably absent from the three citations accompanying this claim is John Boswell's book, Christianity, Social Tolerance, and Homosexuality, ${ }_{161}$ published to public acclain ${ }^{162}$ five years before Bowers. Boswell's book, the product of "nearly a decade" 163 of work, concludes, inter alia: (1) that "Roman society, at least in its urban centers, did not for the most part distinguish gay people from others and regarded homosexual interest and practice as an ordinary part of the range of human eroticism;"164 (2) that the "early Christian Church does not appear to have opposed homosexual behavior per se;"165 and (3) that in the eleventh century, "[h]omosexual passions became matters of public discussion and were celebrated in spiritual as well as carnal contexts. Opposition to gay sexuality appeared rarely and more as aesthetic partisanship than as moral censure; exceptions to this were ignored by religious and civic leaders." 166 The citation of Bailey's book on homosexuality, ${ }^{167}$ and the notable absence of Boswell's book, demonstrates how, and to what effect, the privilege of unknowing can be exercised in this area of jurisprudence. ${ }^{168}$

159. Justice Powell expressed regret over his position in Bowers in a speech to a group of New York University law students: "I think I probably made a mistake in that one... . So far as I'm concerned it's just a part of my past and not very important . . . I don't suppose I've devoted half an hour' to thinking about the decision since it was made." Ruth Marcus, Powell Regrets Backing Sodomy Law, Wash. Post, Oct. 26, 1990, at A3.

160. Bowers, 478 U.S. at 197 (Burger, C.J., concurring).

161. John Boswell, Christianity, Social Tolerance, and Homosexuality (1980).

162. Gore Vidal has characterized this "ferociously learned" book as a breakthrough, insofar as it "obliged even the 'homophobic' New York Times to review it intelligently." Vidal, supra note 124, at 167.

163. Boswell, supra note 161 , at xvii.

164. Id. at 333.

165. Id.

166. Id. at 334.

167. See Bowers v. Hardwick, 478 U.S. 186, 196-97 (1986) (Burger, C.J. concurring) (citing Derrick S. Bailey, Homosexuality and the Western Christian Tradition 70-81 (Archon Books 1975) (1955)).

168. The tone of the Court is just as, if not more, indicative of this exercise of power, as best seen through a juxtaposition of the tone of Boswell's book with that of the majority opinion. In his conclusion, Boswell reflects that:

Beyond these modest conclusions and the facts which support them, little can be asserted with confidence. The social topography of medieval Europe is so unexplored that the writer on this subject cannot hope to avoid leading his readers down many wrong paths or, occasionally, coming to a dead end. His comfort must subsist in the helief that he has at least posted landmarks where there were none before and opened the trails on which others will reach destinations far beyond his own furthest advance. 
Even the Bowers dissent may have similarly deployed the privilege of unknowing. Michael Sandel notes that the dissent based its view on the concept of autonomy rights rather than dealing with homosexuality directly, and thereby rested its defense of homosexuality on an impoverished understanding of it. As Sandel puts it:

The problem with the neutral case for toleration is the opposite side of its appeal; it leaves wholly unchallenged the adverse views of homosexuality itself. Unless those views can be plausibly addressed, even a Court ruling in their favor is unlikely to win for homosexuals more than a thin and fragile toleration. A fuller respect would require, if not admiration, at least some appreciation of the lives homosexuals live. Such appreciation, however, is unlikely to be cultivated by a legal and political discourse conducted in terms of autonomy rights alone. ${ }^{169}$

This criticism of Bowers posits that even the dissenters may have ruled for gays without understanding them. The autonomy principle in this formulation is just another way of keeping homosexuals at arms length; it "tolerates homosexuality at the price of demeaning it."170

These accounts reveal that one distinctive aspect of gay history that cannot easily be translated into relevance in the discourse of equivalents is the invisibility of that history. As noted, the Court appears reluctant to consider such new characteristics for fear that other groups might use them to invoke sympathy for their causes. Yet the invisibility of gay history seems to be a particularly valid trait for consideration, given that it relates directly to the inquiry of the history prong. If the purpose of the history prong is to help the judge educate himself about his vision of the group, surely it would be ironic for the court not to consider the ways in which that group may be hard to see. If a judge is attempting to listen to the biography of a group, surely it must be relevant that the biography will be told in a whisper. Moreover, if the judiciary itself has been com-

Boswell, supra note 161 , at 334 . Contrast the tone of this paragraph with the tone of the White and Burger quotations above. See supra text accompanying notes 157-160. It is White and Burger, on the basis of limited research, who make broad claims concerning the content of "millennia of moral teacbing." Bowers, 478 U.S. at 197 (Burger, C.J., concurring). It is Boswell, who, after almost ten years of research in this field, gestures toward its ambiguity.

169. Michael J. Sandel, Moral Argument and Liberal Toleration: Abortion and Homosexuality, 77 Cal. L. Rev. 521, 537 (1989).

170. Id. It is important on one level to distinguish between the motivations of the majority and the dissent. The dissent probably refused to deal with the concrete instance of homosexuality in part as a political move to gather votes on the Court and sympathy from its readers. It is entirely plausible that even a person with a deep understanding of homosexuality might pitch his discourse toward the "thin," but less controversial, defense of the "rigbt to be let alone" rather than toward a "thick" defense that would force readers to engage with the concrete practice of sodomy. On another level, however, motivations may not be that important. It is precisely Sandel's point that while such tactics may have the obvious benefit of building coalitions, they may have the occluded cost of allowing ignorance about a group to remain unchallenged. 
plicit in that silence, an Ely-inflected reading of the Equal Protection Clause would make that silence a prime trait for judicial consideration.

\section{Political Powerlessness and the Closet}

The second prong of the Equal Protection test inquires whether the group asking for heightened scrutiny is politically powerless. This prong of the test has been criticized as ill-defined, ${ }^{171}$ and courts have struggled to determine the appropriate indicia of political powerlessness. Courts have employed three tests in the gay rights context. The first, developed in Frontiero $v$. Richardson, requires that a group have been excluded from the "Nation's decision-making councils" before the court finds them to be politically powerless. ${ }^{172}$ This test has been applied in only two Equal Protection cases: one sex-discrmination case, Frontiero, and one sexualorientation discrimination case, Equality Foundation v. City of Cincinati. ${ }^{173}$ The second, developed in City of Cleburne, Texas v. Cleburne Living Center, Inc., inquires whether a group has the "ability to attract the attention of the lawmakers."174 It has been applied only to the mentally retarded (Clebume) and gays (four cases). ${ }^{175}$ As noted below, it generally will be easier to find that a group is politically powerful under this test than it is under the Frontiero test. This perhaps explains why courts wishing to find that gays are not politically powerless prefer this test. The third, based on United States v. Carolene Products Co., focuses on whether the class is a "discrete and insular minorit[y]."176 Unlike the other two tests, this test has been widely applied to a variety of different classifications, including

171. See Equality Found. v. City of Cincinnati, 860 F. Supp. 417,437 (S.D. Ohio 1994), rev'd, 54 F.3d 261 (6th Cir. 1995), vacated and remanded, 116 S. Ct. 2519 (1996).

172. 411 U.S. 677,686 n.17 (1973).

173. See Equality Found., 860 F. Supp. at 439.

174. 473 U.S. 432,445 (1985).

175. Three of the courts that explicitly advert to the Clebume test have found that gays are not politically powerless. See High Tech Gays v. Defense Indus. Sec. Clearance Office, 895 F.2d 563, 574 (9th Cir. 1990) (" $[\mathrm{H}]$ omosexuals are not without political power; they have the ability to and do 'attract the attention of the lawmakers,' as evidenced by [several state statutes and local ordinances]." (quoting Cleburme, 473 U.S. at 445)); Ben-Shalom v. Marsh, 881 F.2d 454, 466 (7th Cir. 1989) ("In these times homosexuals are proving that they are not without growing political power. It cannot be said 'they [homosexuals] have no ability to attract the attention of the lawmakers." (quoting Cleburme, 473 U.S. at 445)); Steffan v. Cheney, 780 F. Supp. 1, 9 (D.D.C. 1991) (" [I] t cannot be successfully maintained that our political branches are not paying attention to homosexuals or those who advocate legislation favorable to them."), rev'd en banc on other grounds sub nom. Steffan v. Aspin, 8 F.3d 57 (D.C. Cir. 1993), rev'd en banc on other grounds sub nom. Steffan v. Perry, 41 F.3d 677 (D.C. Cir. 1994). But see Jantz v. Muci, 759 F. Supp. 1543, 1550 (D. Kan. 1991) (finding that "homosexuals face severe limitations on their ability to protect their interests by means of the political process"), rev'd, 976 F.2d 623 (10th Cir. 1992).

176. 304 U.S. 144, 152 n.4 (1938). 
sex, ${ }^{177}$ alienage, ${ }^{178}$ and race. ${ }^{179}$ It has been explicitly applied to gays in one case, Ben-Shalom v. Marsh. ${ }^{180}$ If current gay Equal Protection cases are representative, the courts are most likely to use the Cleburne test in the future. In the interest of comprehensiveness, however, I consider all three.

The organization of this Part reflects its thesis. ${ }^{181}$ It begins with the symbol of the closet because the political powerlessness of gays, regardless of how it is measured, cannot be ascertained without taking into account the effects of the closet. To show how the closet is the philosopher's stone against which any inquiry about gay political powerlessness must be robbed, this Part explores the centrality of the symbol in describing gay oppression. This centrality arises from the symbol's ability to describe the regimes of isolation and invisibility imposed on lesbians and gay men. This Part then turns to doctrine, showing that all three tests are inadequate insofar as they do not, as currently applied in the gay context, account for the effects of the closet. Finally, it considers a brace of cases outside the Equal Protection context to reveal the difference a sensitivity to the closet makes to doctrinal arguments.

\section{A. The Closet}

It is hard to talk about homosexuality without talking about the symbol of the closet. Homosexuals who are not open about their orientation are said to be closeted; indeed, even the word "open" poses itself against the closedness of the closet door. When homosexuals are described as "out," the underlying symbol of the closet is so pervasive that it can be left

177. See, e.g., United States v. Virginia, 116 S. Ct. 2264, 2296 (1996) (Scalia, J., dissenting) ("It is hard to consider women a 'discrete and insular minorit[y].' " (alteration in original)).

178. See, e.g., Sugarman v. Dougall, 413 U.S. 634, 642 (1973) ("[A]liens as a class 'are a prime example of a "discrete and insular" minority." " (quoting Graham v. Richardson, 403 U.S. $365,372(1971))$ ).

179. See, e.g., Richmond v. J.A. Croson Co., 488 U.S. 469, 495 (1989) (plurality opinion of O'Connor, J.).

180. 703 F. Supp. 1372, 1380 (E.D. Wis.) (finding that "homosexuals constitute a discrete and insular group"), rev'd, 881 F.2d 454 (7th Cir. 1989).

181. This discussion of the political-powerlessness prong inverts the order of discussing doctrine before symbol followed for the other two prongs. This is because the theory being expounded is often little more than a back formation from the intuitive sense courts have of the group's political powerlessness. For example, in Cleburne, the Court ignored two existing tests of political powerlessness to create a third. See Clebume, 473 U.S. at 445. The two existing tests-the "presence in the decision-making councils of the nation" test and the "discrete and insular minority" test-clearly would have resulted in a finding that the mentally retarded were politically powerless. Yet the Court, seemingly intent on finding that the mentally retarded were not politically powerless, did not adopt either of those tests, creating instead a third test-the "ability to attract the attention of the lawmakers" test-out of whole cloth. It then "applied" its new test to the case of the mentally retarded for a predictable finding that they were not politically powerless. See id. Following the Court's lead in considering the political powerlessness of gays, I use that determination to "test" the tests, rather than vice versa. 
implicit-there is no follow-up question "out of what?" Our collective inability to reimagine the metaphor reflects and reinforces its fixity. Why not coffin? Why not room? As one commentator noted: "[T] he primary symbol of gay repression hasn't been the ghetto or a list of segregation laws. It's been the much more psychologically complex image of the closet: the dark place where cultural hate meets, and makes, self-hate."182

The landmark work on the closet as a symbol in gay culture is Sedgwick's Epistemology of the Closet. ${ }^{183}$ In this work, Sedgwick argues that the closet has a special ability to describe the oppression of homosexuals because it captures their distinctive invisibility and isolation. ${ }^{184}$ While Sedgwick argues that the closet should be particularly indicative for gays, she does not argue that it is indicative. The latter point can be supported, however, by an exploration of the deployment of the symbol of the "double closet." The trope of the double closet marks the situation in which a person is a member of two minority groups for which the closet is a shaping influence. Examples include persons who are gay and victims of domestic violence, ${ }^{185}$ persons who are gay and Republican, ${ }^{186}$ persons who are gay and affluent, ${ }^{187}$ or persons who are gay and afflicted with AIDS. ${ }^{188}$ That each of the persons in this otherwise diverse group is

182. Ellen Goodman, Gay Policy Won't Work, Dallas Morning News, July 16, 1993, at 23A, available in 1993 WL 8812000.

183. Sedgwick, supra note 131 .

184. While perhaps intuitive, such an assumption is not uncontroversial, for the closet as a metaphor for oppression has been extended beyond the referent of homosexual oppression. Sedgwick gives the examples of a speaker stating that blacks "came out of the closet" in the sixties, and of her own discussion of how it is possible to "come out" as a fat woman. See id. at 72. However, while these examples might suggest that the closet has been "evacuated of its historical gay specificity," Sedgwick posits that precisely the opposite is true. Rather than cutting their moorings from the homosexual/heterosexual distinction, these modern usages of the closet are so indelibly marked with that distinction that they carry it into other discourses. The closet may be a metaphor for many different kinds of oppression, but the deployment of that metaphor becomes intelligible only when funneled back through the oppression suffered by homosexuals. See id.

185. See Jane Lowers, Gay and Lesbian Partners Not Immune to Violence, Chi. SunTimes, Feb. 25, 1995, at 18 ("There's a double closet involved when someone admits that they have been beaten, and that the lover who beat them is of the same sex . ...") (quoting Jerri Lynn Fields, director of the Horizons Community Services Anti-Violence Project).

186. See Jonathan Mandell, Gay Republicans; Log Cabin Club Gets Its Turn, Newsday, Nov. 18, 1993, at 15 (stating that some gay Republicans describe themselves as occupying a "double closet").

187. See Kathleen Teltsch, Young Philanthropists Give to Nontraditional Causes, N.Y. Times, Aug. 2I, 1986, at Cl (quoting David Pillsbury Becker on his homosexuality and wealth: "I lived in a double closet as a member of two minorities, one at the top of society and one near the bottom.").

188. See Eleanor Mallett, Therapist Refuses to Let AIDS Shackle Him, The Plain Dealer, July 27, 1993, at 1C, available in 1993 WL 4303294 (quoting Jim Stuntz, a gay person with AIDS: "I have no more closets to come out of."). 
gay indicates that the primary resonance of the closet is a gay one. This descriptive evidence thus shores up Sedgwick's prescriptive claim. ${ }^{189}$

Accepting, then, that the closet has resonance for homosexuals, we might ask on what lines the analogy between the closet and gay oppression are drawn. As Sedgwick notes, the Oxford English Dictionary [OED] defines the closet variously as:

(1) (a) A room for privacy or retirement; a private room; an inner chamber; ... (b) esp. Such a room as the place of private devotion ...; (c) As the place of private study or secluded speculation; esp. in reference to mere theories as opposed to practical measures; (2) (a) The private apartment of a monarch or potentate ... ; (3) (a) A private repository of valuables; (b) A small side-room or recess for storing utensils, provisions, etc.; a cupboard; (c) skeleton in the closet (or cupboard): a private or concealed trouble in one's house or circumstances, ever present, and ever liable to come into view; ... (4) With special reference to size: Any small room: especially one belonging to or communicating with a larger ... ; (5) The den or lair of a wild beast ... ; (6) (a) That which affords retirement like a private chamber, or which encloses like a cabinet; a hidden or secret place, retreat, recess . . . ; (7) Short for "Closet of ease," "watercloset"; . . . (10) . . . (b) A place of private devotion. ${ }^{190}$

Two different closets emerge from both the $O E D$ and Sedgwick: one with a negative connotation and one with a positive one. Most familiarly, the closet connotes confinement, isolation, and repression, as in its incarnation as a locus for "private or concealed trouble ... . ever present, and ever liable to come into view." 191 Such connotations inhere in Sedgwick's concept of gays as isolated from an immediate usable heritage. The celebratory aspect of coming out thus predicates itself on an opposition to this conception of the closet; what was private and concealed is brought into sociability and light. Call this the confining closet. The positive aspect of the closet, perhaps less familiar to one approaching the symbol from a pro-gay context, is that the closet affords protection-for valuables, for the wild beast, for the person who wishes to "retreat."192 Such privacy is reflected in Sedgwick's concept of the "notional discretion" of gays to choose invisibility. ${ }^{193}$ The cautionary aspect of coming out builds on this model of the closet; what was protected now becomes vulnerable through its visibility. Call this the protective closet.

189. Indeed, the nexus between homosexuality and the closet may be stronger as a descriptive matter than as a prescriptive one. While invisibility and isolation distinguish gay oppression from some oppressions, they only further ally it with other oppressions, such as the oppression directed at persons with AIDS. People with AIDS often have notional discretion of their HIV status, and most adult people with AIDS were not born to people with AIDS.

190. 3 The Oxford English Dictionary 349-50 (2d ed. 1989) [hereinafter OED].

191. Id. at 350.

192. Id.

193. See Sedgwick, supra note 131 , at 75 . 
In both its confining and protective incarnations, the closet contributes to the political powerlessness of gays. As Schacter notes, in its confining aspect, "the closet exacts a high price in self-esteem, emotional health, and access to the community."194 "To show the costs of such confinement, I extend Elaine Scarry's seminal theory of the relationship between the room and the body. I then turn to the less intuitive ways in which the protective closet impedes the political mobilization of gays by increasing tolerance of that confinement.

1. Confining Closet. - While the closet as a confining structure is a domestic symbol, it is not domesticated-the violence suffered within its bounds is real, not mannered. Consider Elaine Scarry's discussion of the body, the room, and torture:

In normal contexts, the room, the simplest form of shelter, expresses the most benign potential of human life. It is, on the one hand, an enlargement of the body: it keeps warm and safe the individual it houses in the same way the body encloses and protects the individual within; like the body, its walls put boundaries around the self preventing undifferentiated contact with the world, yet in its windows and doors, crude versions of the senses, it enables the self to move out into the world and allows that world to enter. But while the room is a magnification of the body, it is simultaneously a miniaturization of the world, of civilization. Although its walls, for example, mimic the body's attempt to secure for the individual a stable internal space-stabilizing the temperature so that the body spends less time in this act; stabilizing the nearness of others so that the body can suspend its rigid and watchful postures; acting in these and other ways like the body so that the body can act less like a wall- the walls are also, throughout all this, independent objects, objects which stand apart from and free of the body, objects which realize the human being's impulse to project himself out into a space beyond the boundaries of the body in acts of making, either physical or verbal, that once multiplied, collected, and shared are called civilization. ${ }^{195}$

Scarry sees the room as the body writ large, for like the body, the room frees the self from certain functions by assuming responsibility for them. Yet while these structures are extensions of the body, they are not part of the body in the way, for example, that an artificial limb or heart might be. Part of the utility of the wall is precisely in its independence from the body, in its ability to be mine rather than me. The room, then, achieves value through its amphibiousness between the inner sphere of the personal and the outer sphere of the social.

Torture, in Scarry's vision, is the subversion of this mediating structure, the disruption of which calls into question both self and world. One

194. Schacter, supra note 107, at 299.

195. Elaine Scarry, The Body in Pain: The Making and Unmaking of the World 38-39 (1985). 
form of this subversion occurs when the structure that represents the extension of the self is turned threateningly back on it:

Just as all aspects of the concrete structure are inevitably assimilated into the process of torture, so too the contents of the room, its furnishings, are converted into weapons: the most common instance of this is the bathtub that figures prominently in the reports from numerous countries, but it is only one among many. ${ }^{196}$

Indeed, torture gains an added edge when a familiar structure is suddenly given a sinister valence, a conversion that itself becomes a metaphor for the dissolution of civilization into brutality.

The symbol of the closet differs from this symbol of the room in that it does not posit an ambient room that has been invaded by another, and whose furnishings are used against the owner. Rather, it configures its pain as a kind of room that is definitionally uncomfortable and unfurnished. There is no invader, save perhaps the threatened one with his hand on the outside knob. The symbol does not need to pose that invader, for the closet itself performs that invasion.

Scarry's analysis of the room, when extended to the closet, is almost uncanny in its ability to reveal the particularities of the oppression of the closeted homosexual. First, if both room and closet are the body writ large,$^{197}$ the closet is not writ large enough. If the room provides crude versions of the senses in its windows and doors, creating a permeable membrane between self and world, ${ }^{198}$ the closet, posed initially with its door firmly closed, is a body that is blind and that cannot feel the external world. If the room stabilizes the temperature to relieve the body of that work, ${ }^{199}$ the closet is, definitionally, "close"-uncomfortable and even suffocating. If the room, through its walls, stabilizes the nearness of others to ensure intimacy, ${ }^{200}$ the closet achieves that distance by giving only enough space for solitude. Thus, while the room draws a charmed circle around an individual, the closet draws a conscribing one, providing senselessness rather than sense, discomfort rather than comfort, solitude rather than intimacy.

Similarly, both room and closet are the world writ small, but the closet is a world overly miniaturized, collapsed into insignificance. The walls of a room, Scarry states, realize the human being's impulse to project himself outward, and in their independence from the body represent the acts of making that are the constitutive parts of civilization. Similarly, the furniture in the room is enough not like the self to provide the self with relief from the discomfort it would suffer on its own.

196. Id. at 40 .

197. See id. at 38.

198. See id.

199. See id. at 39.

200. See id. 
Both in the details of its outer structure and in its furniture (from "furnir" meaning "to further" or "to forward," to project oneself outward) the room accommodates and thereby eliminates from human attention the human body: the simple triad of floor, chair, and bed (or simpler still, floor, stool, and mat) makes spatially and therefore steadily visible the collection of postures and positions the body moves in and out of, objectifies the three locations withm the body that most frequently hold the body's weight, objectifies its need continually to shift within itself the locus of its weight, objectifies, finally, its need to become wholly forgetful of its weight, to move weightlessly into a larger mindfulness. ${ }^{201}$

Close and unfurnished, the closet denies the right of the body to project itself outward. It provides only a floor (and only a floor to stand on), thereby denying the body's "need continually to shift within itself the locus of its weight." 202 With that denial, it ensures that the body will never be able to forget itself, or move "into a larger mindfulness." 203 The closet teaches the body misplaced within it to be obsessively conscious of its discomfort and thus of itself.

If the closet provides a symbol for gay pain, it also has nested within it the means of liberation. The closet is a place of storage or for visitation rather than a place of habitation-a person who resides there is on the wrong side of the door. That imtuition of misplacement is abetted by the fact that closet doors never remain closed. In quotidian life, the utility of closets rests on their ability to be opened and closed, they are not designed as places where things are lost beyond retrieval, they are "[a]ny small room: especially one belonging to or communicating with a larger [one]."204 To compare gay oppression to the body's confinement in the closet is to retain liberation as normative. Indeed, while the closet may be locked, there is something unnatural about a closet (or room) that is perpetually locked. We know that the sanctums of the fairy taleBluebeard's closet, ${ }^{205}$ the king's room in Trusty John, ${ }^{206}$ and the room of the Master Maid ${ }^{207}$ - are closed up with the strictest injunction that they should never be opened. We also know, from the moment the injunction is delivered, that both it and the closet will be breached.

Most obviously, the closet is not the body. The symbol of the closet is analogous to the body in that both are loci of entrapment. The closet traps the homosexual body within its confines just as the man's body traps the woman's nature (or vice versa) in the theory of homosexual "inver-

201. Id.

202. Id.

203. Id.

204. OED, supra note 190 , at 350 (emphasis added).

205. See Blue Beard, in The Blue Fairy Book 356 (Andrew Lang ed., 1948).

206. See Trusty John, in The Blue Fairy Book, supra note 205, at 363.

207. See The Master Maid, in The Blue Fairy Book, supra note 205, at 148. 
sion."208 In both cases, moreover, the cure for the tension between the container and the contained is the removal of the latter from the former. The two symbols differ, however, in the relative value they place on the container and the contained. In the case of inversion, the container is the valued object, and the contained is removed as an act of exorcism. The object of science, psychology, and religion has been to cast homosexuality out of the body. In the case of the closet, the contained is more valuable than the container, making removal a liberation rather than a purge. It is not homosexuality that must come out of the body, but the homosexual body that must come out of a confining structure. The relative value placed on container and contained, of course, reflects a difference in value placed on homosexuality itself.

2. Protective Closet. - The negative effects of the protective closet on gay political mobilization may seem less clear, because the closet in this formulation possesses a benign aspect. It provides a "rooun for privacy or retirement"209 or a "place of private study or secluded speculation,"210 spaces in which to amass the intellectual and spiritual resources that are needed in the world beyond. The injunctions against "outing" made by the gay comununity seem implicitly motivated by the understanding that the closet is a protective structure, and that to force someone out prematurely is an act of violence. ${ }^{211}$ The protective aspects of the invisibility afforded by the closet might militate for a finding of political power. As noted, the Court seems to share the view that, ceteris paribus, invisibility leads to greater power for a minority: illegitinates were deemed more powerful because they were invisible while women were deenned less powerful because they were not.212

While the closet has a benign aspect, that aspect nonetheless has a negative impact on gay mobilization. The protective aspects of the closet have sinister long-term implications. The comfort provided by the closet prevents people from going into a radically uncomfortable world. While the closet may be a small room "belonging to or communicating with a larger [one],"213 it often can be experienced as a room that belongs to nothing and cominunicates with nothing. The homosexual's sojourn in the closet is a benign tenancy but an oppressive residency. ${ }^{214}$ When one

208. See Sedgwick, supra note 131 , at 87 ("[T]here was, and there persists . . . the trope of inversion, anima muliebris in corpore virili inclusa-a woman's soul trapped in a man's body'-and vice versa."). Indeed, some writers have analogized the closet to the body: "We see [our souls] bound . . . to the narrow closet of a man's body." OED, supra note 190, at 350; see also id. ("This skinne ... is also called the litle closet of the heart.").

209. OED, supra note 190 , at 349 .

210. Id.

211. See, e.g., Gross, supra note 151, at 1-2 (1993); Michelangelo Signorile, Queer in America 70-77 (1993).

212. See supra text accompanying notes 112-113.

213. OED, supra note 190 , at 350 .

214. See Stanley Siegel \& Ed Lowe, Jr., Uncharted Lives: Understanding the Life Passages of Gay Men 67-68 (1994). 
settles into the closet, the contemplative life begins to sap the active one, and the closeted person can be cautioned about the dangers of an overly cloistered life. ${ }^{215}$ As Chesterfield noted in 1746, "The knowledge of the world is only to be acquired in the world, and not in a Closet." 216

One objection to the argument that the gay closet is oppressive even in its protective aspects is that gays may choose at any time to leave it. If gays stay closeted, the objection goes, they are exercising a choice to einphasize privacy over visibility, and choice implies power. While more options create more power for the individual, however, they might not create more power for the group. As Ackerman has noted, the fact that gay individuals can exit (or not enter) their group adversely affects their political mobilization. ${ }^{217}$ The history of women's ability to refuse jury service illustrates this dynamic. ${ }^{218}$ In Hoyt $v$. Florida, for exainple, the Court upheld a Florida statute that allowed women to choose to serve on a jury but which required men to do so, observing that a "woman is still regarded as the center of home and family life."219 While this ostensibly gave individual women more power than individual men by allowing them to take refuge in the protective structure of the home, it disempowered woinen as a group in the community vis-à-vis inen by sapping their participation on juries. Similarly, by taking individual solace in the structure of the closet, individual gays deprive their communities of accountable members.

Seen in this light, the closet fashions a prisoner's dilemma, which can be represented by the familiar two-by-two matrix: ${ }^{220}$

215. See id.

216. OED, supra note 190, at 349 (quoting 3 The Letters of Philip Dormer Stanhope, Fourth Earl of Chesterfield 779 (Bonamy Dobree ed., 1932); see also id. at 350 ("'We see [our souls] bound ... to the narrow closet of a man's body.") (quoting Nathaniel Fairfax, A Treatise of the Bulk and Selvedge of the World 147 (1674); id. at 349 ("' [I]n their closets they make men exactly suited to their systems; but . . . such men as exist nowhere else." ) (quoting 1 The Life of Gouverneur Morris 311 (Jared Sparks ed. 1832)).

217. See Ackerman, supra note 40, at 724-26.

218. I am indebted to Akhil Amar for this example.

219. 368 U.S. 57, 62 (1961). Hoyt was effectively overruled by Taylor v. Louisiana, 419 U.S. 522 (1975).

220. The assumption underlying the dilemma is that one person who "benefits greatly" cannot exceed the sum of two people who "benefit." Thus the top left corner maximizes communal utility. 


\begin{tabular}{|l|l|l|}
\hline & $A$ Comes Out & $A$ Remains Closeted \\
\hline$B$ Comes Out & $\begin{array}{l}A \text { benefits } \\
B \text { benefits } \\
\text { (Cooperative } \\
\text { Liberation) }\end{array}$ & $\begin{array}{l}A \text { benefits greatly } \\
\text { B benefits minimally } \\
\text { ( } A \text { freerides on } B)\end{array}$ \\
\hline$B$ Remains Closeted & $\begin{array}{l}A \text { benefits minimally } \\
B \text { benefits greatly } \\
\text { ( } B \text { freerides on } A)\end{array}$ & $\begin{array}{l}A \text { benefits minimally } \\
B \text { benefits minimally } \\
\text { (Mutual } \\
\text { Disempowerment) }\end{array}$ \\
\hline
\end{tabular}

The prisoner's dilemma teaches that in the absence of the ability to communicate, parties will not reach the communally optimal solution, because their individual value-maximizing choices will push them toward the bottom right-hand box. The closet, of course, is a good metaphor for the prison cell posited by the prisoner's dilemma, insofar as it prevents parties from communicating with each other. A cannot get the information he needs about B's likely action because the question: "If I come out, will you come out too?" is a speech act that performs the coming out at issue even as it is posed. The often-voiced desire among gay activists that all gays would turn a distinctive color (thereby making them into a new "race") 221 is a desire to overcome the prisoner's dilemma; that desire highlights that the closet, protective as it is for individuals, hurts the political vitality of the community.

\section{B. Political Powerlessness}

How well, then, do each of the three conventional tests of political powerlessness-the Frontiero test, the Cleburne test, and the Carolene testcapture the oppression of the closet? This Part now turns to doctrine to show that each test fails to measure the political powerlessness of gays accurately because each in its different way fails to understand how the closet shapes that political powerlessness. The Part concludes by demonstrating that such understanding is not an unattainable ideal. An example of a court exhibiting an admirable understanding of the effects of the closet on gay powerlessness can be found, although it arises from the privacy context rather than the Equal Protection context. A comparison of two cases in the privacy context-one which does not consider the closet and one which does-underscores the importance of this understanding.

1. The Frontiero Test. - The Frontiero test asks whether a group is represented in the "decisionmaking councils" of the country. ${ }^{222}$ As applied to gays, it suffers from the obvious defect of failing to distinguish

221. See, e.g., Gross, supra note 151, at 49 ("I have often wished that all gay people would turn blue at the same moment and thereby put an end to our oppression .....) (quoting Nancy Walker, Yanking Them Out, Gay Community News, May 14, 1983, at 5).

222. Frontiero v. Richardson, 411 U.S. 677,686 n.17 (1973). 
between closeted and out members of decisionmaking councils. ${ }^{223}$ The panel of the Seventh Circuit Court of Appeals that employed this test in the gay context stated that "[h]omosexuals are not without political power. Time magazine reports that one Congressman is an avowed homosexual, and that there is a charge that five other top officials are known to be homosexual."224.

Even if one grants this claim, of course, this is an absurd argument, as six Congressmen do not political power make. ${ }^{225}$ But consciousness about the closet renders patent the real irony in Ben-Shalom: the court's reliance on the five politicians "charged" with being homosexuals. The only source cited for the proposition that these politicians are reputedly gay is entitled "How to Spread a Smear," indicating that the top officials were "smeared" by the identity of being gay. ${ }^{226}$ The court does not consider that advocates who have to be "charged" with having a particular group identification are unlikely to be effective advocates for that group. 227 Indeed, closeted Members of Congress, especially those charged with being homosexual, may be precisely the people who need to prove they are not homosexual by distancing themselves froin gay interests and even supporting anti-gay legislation. As Sedgwick notes: "[I]t is entirely within the experience of gay people to find that a hoinophobic figure in power has, if anything, a disproportionate likelihood of being gay and closeted."228

One argument against the assertion that only "out" gays should be counted is that Frontiero does not make any distinction between whether a person acknowledges his or her minority group status. The number of

223. I employ the terms "closeted" and "out" here in the way they are commonly used. I further explore (and contest) that common usage below. See infra notes 263-264 and accompanying text.

224. Ben-Shalom v. Marsh, 881 F.2d 454, 466 n.9 (7th Cir. 1989) (citing Margaret Carlson, How to Spread a Sexual [sic] Smear, Time, June 19, 1989, at 33 (the court mistakenly added the word "Sexual" before "Smear")).

225. In Frontiero, the fact that there were only fourteen women in Congress was sufficient to find political powerlessness. See Frontiero, 411 U.S. at 686 n.17.

226. See Ben-Shalom, 881 F.2d at 466 n.9.

227. As Judge Norris noted in Watkins $v$. United States Army: "[T] and political pressures to conceal one's homosexuality commonly deter many gays from openly advocating pro-homosexual legislation, thus intensifying their inability to make effective use of the political process." 847 F.2d 1329, 1348 (9th Cir.), vacated en banc, 875 F.2d 699 (9th Cir. 1989).

228. Sedgwick, supra note 131, at 81; see also id. at 242-46 (giving examples). Janet Halley reproduces part of a Studs Terkel interview with Ted Allenby, a Marine dishonorably discharged for his homosexuality:

TERKEL: Did you take part in the banter?

ALLENBY: Of course. You have to, otherwise somebody'd suspect you. You develop quite a repertory of tricks to prevent detection. Be even more vociferous than everybody else.

Janet E. Halley, The Politics of the Closet: Towards Equal Protection for Gay, Lesbian, and Bisexual Identity, 36 UCLA L. Rev. 915, 934 n.67 (1989) (quoting Studs Terkel, The Good War: An Oral History of World War Two 180 (1984)) (emphasis added). 
women in Congress was relevant for the purposes of the test, but the political views of the women were not. Similarly, the argument would run, the test as applied to gays properly counts the number of homosexuals, rather than their anti-gay political views. This argument, however, fails precisely because it ignores the dynamic of the closet that allows persons to reject their identity in a way that is impossible for members of minorities that have visible differentiating traits. The closeted homosexual is not saying "I am gay but I will not always vote gay," but rather "I am not gay." The equivalent is thus not the woman who states "I am not a feminist," but rather the woman who says "I am not a woman." The very absurdity of a woman denying her identity in this manner raises the presumption that the issue of persons of minority groups disavowing their identities was not one that concerned the Frontiero Court when it discussed exclusion from our "Nation's decisionmaking councils."229 By counting closeted gays in their tallies, courts risk adding what they should be subtracting from their estimates of gay power; an unmodified application of the Frontiero test thus systematically overestimates gay power.

Regardless of whether one chooses to modify the Frontiero test, it will be of only limited value because the total number of gays in the country is not known. Power is a ratio, not an absolute number: political power in the nation's decisionmaking councils cannot be assessed without an understanding of the size of the constituency being represented. The lower a court's estimate of gays in the population, the more likely it will be to interpret a given presence as indicating power. Conversely, the higher a court's estimate of gays in the population, the more likely it will be to interpret a given presence as indicating powerlessness. The problem with assessing this ratio in the context of gays is that one of its terms is obscured-call this the problem of the "closeted denominator."230

229. Frontiero v. Richardson, 411 U.S. 677,686 n.17 (1973).

230. Bruce Bawer summarizes the "numbers game" as follows:

There is no other prejudice whose practitioners play numbers games. From the appearance of the Kinsey Reports in 1948 and 1953 until very recently, it was a truism that about 10 percent of Americans are homosexual. This would make the gay population roughly equal to that of blacks and Hispanics and four times that of Jews. Some gays thought the percentage was even higher; others would have placed it closer to six or seven. Homophobes made a point of disputing these numbers, as if they found unbelievable or intolerable, or both, the very idea that so many Americans were gay, and as if it were somehow more permissible to abuse a smaller minority than a larger one. These homophobes argued that gays make up only 3 or 4 percent of the population, or even as little as 1 or 2 . They based these figures on surveys in which people are asked if they have ever had "homosexual intercourse." One problem with using the results of such surveys to determine the percentage of gays in the population is that many gays have never had "homosexual intercourse," if by that term one means anal penetration; another problem, of course, is that a large percentage of gays are so deeply closeted that they would never respond truthfully to such a survey.

Bruce Bawer, A Place at the Table: The Gay Individual in American Society 82 (1993). 
When closeted gays are properly excluded from the headcount, gay presence in the nation's decisionmaking councils is so minuscule that it seems that any plausible estimate of the number of gays in the population would lead to a finding of political powerlessness. However, the closetedness of the denominator allows judges to substitute their own private estimates. If lack of exposure to gays leads to underestimating their numbers, ${ }^{231}$ such a substitution may have adverse consequences. This is because judges may be particularly prone to underestimating the gay population. As Judge Posner has noted: "[J]udges know next to nothing about [sex and sexuality] beyond their own personal experience, which is limited, perhaps more so than average, because people with irregular sex lives are pretty much ... screened out of the judiciary."232 The degree to which gays are underrepresented in the nation's decisionmaking councils will only become apparent when gays are more visible in the general population. ${ }^{233}$ Ironically, that visibility is not likely to occur until gays become more politically empowered and therefore less needful of judicial protection.

2. The Cleburne Test. - The Cleburne test inquires whether the group has been able to get the "attention of lawmakers." 234 The test focuses not on the number of group members, but rather on the number of group sympathizers, in the legislature. ${ }^{285}$ The common indicia that a group has earned "the attention of lawmakers," such as the amount of pro-gay legislation passed, are reasonably objective and have not been seriously contested. For example, it is uncontested that there are state statutes, executive orders, and municipal regulations that prohibit discrimination against gays. ${ }^{236}$ Yet there is great controversy about how to interpret this data. Courts have used identical evidence regarding progay legislation as indicative of both gay power ${ }^{237}$ and powerlessness. ${ }^{238}$

231. I realize that this assumption may be contestable, but it seems intuitively plausible.

232. Posner, supra note 17 , at 1 .

233. See City of Cleburne, Tex. v. Cleburne Living Ctr., Inc., 473 U.S. 432, 466 (1985) (Marshall, J., dissenting) (noting irony that "the only discrimination courts may remedy is the discrimination they alone are perspicacious enough to see" because once legislature takes note, courts' hands are tied.).

234. Id. at 432.

235. While it is not necessarily true that sympathizers would outnumber members (because, as the case of gays indicates, members are not necessarily sympathizers) one would generally expect this to be the case, making a finding of political powerlessness under the Cleburne standard more likely than under Frontiero.

236. For an often cited summary, see Note, Developments in the Law-Sexual Orientation and the Law, 102 Harv. L. Rev. 1508, 1667-68 (1989) [hereinafter Developments].

237. See High Tech Gays v. Defense Indus. Sec. Clearance Office, 895 F.2d 563, 74 \& n.10 (9th Cir. 1990) (identifying antidiscrimination legislation as a sign of political potency for gays and citing Developments, supra note 236, at 1667-68).

238. See Jantz v. Muci, 759 F. Supp. 1543, 1550 (D. Kan. 1991) (citing Developments, supra note 236 , at 1667 n.49, 1668 n.51). 
Courts that attempt to adduce evidence that gays are politically powerful, however, are convicted by their own words. One court stated that "[o]ne need only remember St. Patrick's Day 1991 in New York City to see Mayor David Dinkins marching in the traditionally Irish-Catholic parade with homosexual groups and activists who were important supporters during his tough mayoral campaign."239 The court does not ask why one can be expected to remember this event. Dinkins marching with the gays is memorable because it is the exception that proves the rule of politicians not wanting to support gays.

The closet, of course, cannot account for all the obstacles gays face in garnering the sympathy of legislators. Like any other stigmatized group, gays have difficulty because supporters risk acquiring some of that stigma through association. As Judge Norris noted in Watkins v. United States Army, gays have difficulty forming cross-group coalitions because "[e]lected officials sensitive to public prejudice may refuse to support legislation that even appears to condone homosexuality."240 The Army had ascribed this reluctance to the fact that toleration might be seen as tacit approval of homosexuality. ${ }^{241}$ While this is a serious problem, it is not confined to minorities for whom the closet is a shaping influence. If blacks, for example, are stigmatized, pro-black supporters will be tainted through association as well.

On the other hand, when attempting to form cross-group coalitions, gays encounter three problems that are not faced by minorities who are unaffected by the closet. First, the problem of the closeted denominator recurs. As Judge Canby noted in his dissent from a denial of rehearing en banc in High Tech Gays:

Compare the situation [of gays] with that of blacks, who clearly constitute a suspect category for equal protection purposes. Blacks are protected by three federal constitutional amendments, major federal Civil Rights Acts of 1866, 1870, 1871, 1875 (ill-fated though it was), 1957, 1960, 1964, 1965, and 1968, as well as by antidiscrimination laws in 48 of the states. By that comparison, and by absolute standards as well, homosexuals are politically powerless. ${ }^{242}$

Judge Canby thus assumes that the number of gays cannot be so much smaller than the number of blacks that it would justify a finding that gays are politically powerful while blacks, who have much more legislation passed in their favor, are deemed politically powerless. Indeed, in argu-

239. Steffan v. Cheney, 780 F. Supp. 1, 8-9 (D.D.C. 1991), rev'd sub. nom. Steffan v. Aspin, 8 F.3d 57 (D.C. Cir. 1993), rev'd sub nom. Steffan v. Perry, 41 F.3d 677 (D.C. Cir. 1994) (en banc).

240. 847 F.2d 1329, 1348 (9th Cir.), vacated en banc, 875 F.2d 699 (9th Cir. 1989) (citing Note, The Constitutional Status of Sexual Orientation: Homosexuality as a Suspect Classification, 98 Harv. L. Rev. 1285, 1304 n.96 (1985)).

241. Id. at 1348 (citing Army's Opening Brief at 17, 19 n.9, 30 n.18).

242. High Tech Gays v. Defense Indus. Sec. Clearance Office, 909 F.2d 375, 378 (9th Cir. 1990) (Canby, J., dissenting from denial of rehearing en banc). 
ing that "by absolute standards as well, homosexuals are politically powerless," Judge Canby notes that no reasonable estimate of gays could permit a finding that gays were not powerless. ${ }^{243}$ The indeterminacy of the gay population in the United States may thus appear moot until the amount of pro-gay legislation grows in significance. However, this indeterminacy serves anti-gay purposes, insofar as it allows judges to evade the force of Judge Canby's analogy by obscuring the statistic that would cinch the analogy tight.

Second, the closet decreases the likelihood of cross-group empathy. Cross-group empathy means that "[o]ne can empathize without having been there."244 Political power thus depends not only on the number of group members, but on the number of group empathizers. People achieve such empathy by rubbing elbows with others: "The more we get to know people who are different in some ways, the more we will begin to appreciate the ways in which they are not, which is the beginning of political cooperation." 245 While most male legislators will never be women, most will have intimate relationships with women. We can expect these relationships to do some of the work of "internalizing" the costs of burdensome legislation. When such relationships do not exist, however, we need to be more careful. As Ely notes, legislators are likely to interact with homosexuals, ${ }^{246}$ and with other non-homosexuals who are also hurt by homophobia. ${ }^{247}$ However, because of the closet, legislators may not know that they are doing so. Thus, stereotypes "are likely to remain fixed, given our obliviousness to the fact that the people around us may well be counterexamples."248

Finally, just as the closet makes it unclear that gays are gay, it also makes it unclear that straights are straight. Because gays can masquerade as straight, every person who holds himself out as "straight" is suspect. Straights who support gays thus risk being cast as gay themselves, and are

243. See id. (Canby, J., dissenting from denial of rehearing en banc).

244. Ely, supra note 37 , at 160 .

245. Id. at 161 (citations omitted).

246. See id. at 162.

247. See id. Homophobia often affects non-homosexuals, in part through the thirdparty harms caused by closeted homosexuals. As Bawer notes, "the perpetuation of the closet is harmful not only to homosexuals but to society at large. It harms the woman who marries a secretly gay man and one day, perhaps after twenty years of marriage, finds him in bed with another man. It harms the children of such unions." Bawer, supra note 230, at 68.

248. Ely, supra note 37, at 163 . Jeffries recounts one conversation between Powell and his gay clerk as follows:

When told that (as the clerk believed) 10 percent of the population was gay, Powell was incredulous. "I don't believe I've ever met a homosexual," he told his astonished clerk. "Certainly you have" came back the reply, "but you just don't know that they are." In North Africa, Powell said, "not a single episode of homosexuality was reported" despite several months away from women, but the clerk insisted that the behavior would have occurred without Powell's knowledge. Jeffries, supra note 141, at 521. 
deterred from expressing pro-gay sympathies. As Janet Halley notes, "one's mere participation in political action to alter laws affecting gays and lesbians can precipitously earn one a public homosexual identity."249 Straights who feel that they cannot afford to be perceived as gay thus will eschew any association with gays. As the Ben-Shalom v. Secretary of the Army court noted:

No soldier would dare be caught reading anything that might be construed as a homosexually-oriented book or magazine. No soldier would want to be observed in the company of any person suspected of being a homosexual. Most importantly, no soldier would even want to make any statements that might be interpreted as supporting homosexuality. ${ }^{250}$

The invisibility of homosexuality forces all pro-gay advocates, straight or gay, to assume the social costs of being gay. The military makes gay advocacy potentially career-ending, and therefore prohibitively costly. Even when the consequences of gay advocacy are not career-ending, they will dissuade those with limited political capital from investing it in pro-gay causes. Consider a politician faced with the choice of forming a coalition with a gay group or a racial group of comparable power. ${ }^{251}$ Given that both groups have the same power, the politician will get the same benefit from either of them. However, the costs the politician incurs by allying with gays are much higher than those he incurs by allying with the racial group. The white who defends blacks is a "nigger-lover," but not a "nigger"; the straight who defends gays is a "queer-lover," and a possible "queer." Viewed solely from a utility-maximizing perspective, therefore, a rational straight legislator will never form an alliance with gays if a comparable group with a visible differentiating characteristic can be found.

3. The Carolene Products Test. - A third test for political powerlessness asks whether gays are a "discrete and insular" minority. This standard comes from the famous footnote in Carolene Products, which states in part that "prejudice against discrete and insular minorities may be a special condition ... curtail[ing] the operation of those political processes ordinarily to be relied upon to protect minorities, and [so] may call for a correspondingly more searching judicial inquiry."252

Bruce Ackerman has criticized the "discrete and insular" language as having outlived its usefulness. ${ }^{253} \mathrm{He}$ argues that "discrete and insular" minorities, in actuality, may be more politically powerful than "anonymous and diffuse" minorities, because the former have less of a free-rider

249. Halley, supra note 228 , at 973 .

250. 489 F. Supp. 964,974 (E.D. Wis. 1980).

251. The word power rather than size is appropriate here, given that, as described below, a gay group is likely to have less power than a racial group of comparable size. In order to isolate the stigma at issue here, it is necessary to control for the power differential.

252. United States v. Carolene Prods. Co., 304 U.S. 144, 153 n.4 (1938).

253. See Ackerman, supra note 40 , at 717. 
problem, ${ }^{254}$ lower organizational costs, ${ }^{255}$ and greater influence over election outcomes. ${ }^{256}$ Ackerman further warns that the "discrete and insular" standard may be deployed to withhold protection from groups that are disadvantaged in the bargaining process in the precise manner the Carolene Products Court sought to correct. ${ }^{257}$

Even if one atteinpts to argue within the doctrinal language, its inplications for gays are not clear. Gays might be characterized as "anonymous and diffuse" or as "discrete and insular."258 On the one hand, many "closeted" gays live out their lives without ever disclosing their homsexuality to another person. In order to protect the integrity of their closets, they must eschew the company of other homosexuals. Such gays might be characterized as "anonymous and diffuse."259 On the other hand, "out" gays band together by living in the gay ghettos of major urban areas like New York or San Francisco, frequenting gay establishments, and establishing social networks of "families they choose" consisting of other gay persons. ${ }^{260}$ After relinquishing the protection of the closet, homosexuals are so threatened with prejudice that they need an

254. See id. at 724-26.

255. See id. at 726.

256. See id. at 726-28.

257. See id. at 745-46. Judge Posner notes that some groups that traditionally have been thought to be "discrete and insular" no longer merit that description. However, he disagrees with Ackerman's conclusion that the standard has outlived its usefulness. Rather, he contends that the groups have outlived their need for protection. He states: "It is no longer true that blacks or Jews or Orientals or even American Indians constitute 'discrete and insular minorities' despised by a politically, economically, and socially dominant majority ... or that these groups lack political power ...." Richard A. Posner, The Federal Courts: Crisis and Reform 188 (1985) (quoting Carolene Products, 304 U.S. at 152 n.4).

258. See Hunter, supra note 8, at 97.

259. It would be an oversimplification to say that closeted gays relinquish all of their political power. One notable way in which closeted gays are not politically powerless is the manner in which they vote. The anonymity of the American voting process allows even the closeted citizen to wield power at the polls. The voting booth itself may be seen as a kind of protective closet, safeguarding gays under the more general mantle of giving people the privacy to vote their conscience. Yet two counterpoints should also be noted. First, closeted gays themselves must be divided into gays who are closeted to themselves or who admit their homosexuality but suppress it and those who are closeted to others out of fear of external repercussions but who have a pro-gay consciousness. Anonymity will not make the former group vote pro-gay, while it might well allow the latter group to do so. Treating closeted gays as a uniform group that can take advantage of the anonymity of the voting booth is thus an error. Second, as Ackerman notes, the Carolene Products footnote was not directed solely at persons who were denied the vote. See Ackerman, supra note 40, at 715-17. To the contrary, the footnote specifically aims to protect enfranchised persons disempowered in other ways. Thus, even if all closeted gays voted pro-gay in the voting booth, their disempowerment in other aspects of their life would still make them a cause for concern under Carolene Products.

260. See Hunter, supra note 8 , at 97. 
alternative mechanism of protection. ${ }^{261}$ Many find this in numbers; that is, in insularity. These gays may be described as "discrete and insular."262

Having thus complicated the picture of the gay political community, it is tempting to summarize by describing that community as comprised of two kingdoms-one discrete and insular, one anonymous and diffuse-divided by the closet door. Yet even this more sophisticated characterization will not lie pat, for it implies that each individual gay can be placed definitively inside or outside the closet. However, this is one of the ways in which the closet metaphor, by positing a binary of "in" and "out," fails to describe the experience of gay men and lesbians. As Sedgwick writes:

Even at an individual level, there are remarkably few of even the most openly gay people who are not deliberately in the closet with someone personally or economically or institutionally important to them. Furthermore, the deadly elasticity of heterosexist presumption means that, like Wendy in Peter Pan, people find new walls springing up around them even as they drowse: every encounter with a new classful of students, to say nothing of a new boss, social worker, loan officer, landlord, doctor, erects new closets whose fraught and characteristic laws of optics and physics exact from at least gay people new surveys, new calculations, new draughts and requisitions of secrecy or disclosure. Even an out gay person deals daily with interlocutors about whom she doesn't know whether they know or not; it is equally difficult to guess for any given interlocutor whether, if they did know, the knowledge would seem very important. Nor-at the most basic level-is it unaccountable that someone who wanted a job, custody or visiting rights, insurance, protection from violence, from "therapy," from distorting stereotype, from insulting scrutiny, from simple insult, from forcible interpretation of their bodily product, could deliberately choose to remain in or to reenter the closet in some or all segments of their life. The gay closet is not a feature only of the lives of gay people. But for many gay people it is still the fundamental feature of social life; and there can be few gay people, however courageous and forthright by habit, however fortunate in the support of their immediate communities, in whose lives the closet is not still a shaping presence. ${ }^{263}$

Gays can never be out and be done with it; they must continually reiterate their sexual orientation against a heterosexist presumption that reinstates itself at every pause. ${ }^{264}$ The most damaging failure of the closet symbol is

261. See id.

262. See id.

263. Sedgwick, supra note 131 , at 68 .

264. Gays tired of doing the work of coming out verbally sometimes choose to do it performatively. Signs like an earring in the right ear, a pink triangle button, a "fag tag," a necklace of freedom rings, are used to counter default presumptions of heterosexuality in ways that words cannot. Such a relinquishment of control over one's identity, however, 
perhaps that it misrepresents the continuum of a person's disclosure of his or her homosexual orientation as a binary constructed from the endpoints of that continuum. One is either "out" or "closeted": the closet with its rigid door between the "outside" and the "inside" does not lend itself to subtler gradations. However, these gradations are not only relevant, but crucial to an understanding of gay oppression. First, gays come out in a gradual process that is misrepresented by a construct that marks some point as the point at which they "come out." Second, most gays disclose their homosexuality to some but not to others-for example to their families but not their co-workers, or vice versa -in a way that the closet, which does not perform such discrimination between audiences, fails to reflect. Finally, because it is impossible for any gay to be fully "out" or "closeted," the endpoints of the continuum on which the binarism is based do not exist.

This reinforces Ackerman's thesis that the "discrete and insular" test derived from the Carolene footnote is of limited use in the evaluation of political powerlessness. Moreover, even if the test were generally appropriate, it would be hard to apply in the case of gays, since gays are both "discrete and insular" and "anonymous and diffuse." Once again, when we use a traditional test to measure gay political powerlessness, we discover that it fails to capture the shaping influence of the closet, and therefore fails to capture gay identity.

4. Closet Cases: Sipple and Coors. - Any mquiry about gay political powerlessness that does not consider the effects of the closet is necessarily reductive. No court considering an Equal Protection claim has invoked the closet explicitly in its discussion of heightened scrutiny for gays. However, a pair of cases outside the Equal Protection context demonstrate the practical consequences of an understanding of the closet. Each case weighed the right of gays to keep their homosexuality private against the right of others to disclose it. In the first, Sipple v. Chronicle Publishing Co., the court failed to consider the closet in its analysis favoring disclosure, although the symbol might have resolved one of the seeming contradictions in the opinion. ${ }^{265}$ In the second, Adolph Coors Co. v. Wallace, the court appeared to privilege privacy over disclosure (although it remanded the case for further consideration of the issue) by relying heavily on the symbol of the closet. ${ }^{266}$ Obviously, there are numerous ways of explaining why these courts reached their different results, but a juxtaposition of these cases shows that an understanding of the closet might explain that difference.

may have severe costs, as stories of gays bashed simply for such visible proof of identity indicate. See, e.g., American Values, Orlando Sentinel, July 3, 1993, at Al6, available in 1993 WL 5231148.

265. See 201 Cal. Rptr. 665 (Ct. App. 1984).

266. See 570 F. Supp. 202, 209 n.24 (N.D. Cal. 1983). 
Oliver "Bill" Sipple foiled an assassination attempt on President Ford, and newspapers reporting on the event disclosed that he was gay. ${ }^{267}$ Sipple brought suit against these newspapers alleging tortious invasion of privacy. ${ }^{268}$ He stated that publication of his sexual orientation was offensive to him "inasmuch as his parents, brothers and sisters learned for the first time of his homosexual orientation; and that as a consequence of disclosure of private facts about his life [he] was abandoned by his family, exposed to contempt and ridicule causing him great mental anguish, embarrassment and humiliation." 269 The trial court granted summary judgment to the defendants. ${ }^{270}$ The court of appeals affirmed, resting its determination in part on the finding that Sipple's homosexuality was not a private fact. 271 In making this finding, the court noted that Sipple spent time in areas of San Francisco and other cities known to be gay haunts, that he marched in gay parades, that he was friends with prominent homosexuals, and that his name and sexual orientation had been reported in various gay magazines. ${ }^{272}$ The court concluded that because Sipple's "sexual orientation was already in the public domain and since the articles in question did no more than to give further publicity to matters which appellant left open to the eye of the public, a vital element of the tort was missing, rendering it vulnerable to summary disposal."273

The court's reasoning seems cogent: after all, if one discloses some information to a large group of people, it seems reasonable that one thereby assumes the risk that this information may be made generally public by the media. Yet this train of reasoning does not explain a fundamental contradiction in the two pictures of Sipple that emerge from the case. One picture is of a person who has integrated his homosexuality into his public life: Sipple marches in parades, hobnobs with gay activists, and figures in the gay press. ${ }^{274}$ The other is of a person who keeps his homosexuality intensely private from his parents, brothers, and sisters. ${ }^{275}$ Far from attempting to resolve this contradiction between Sipple's public and private homosexual identity, the court catches him in it. The court portrays Sipple as the most irrational of actors-the politically active figure who is afraid that someone will tell his mother on him.

"Irrationality" may be one explanation of this contradiction, but the closet provides a better one. In avoiding any discussion of the closet, the court refused to entertain the possibility that Sipple's seemingly paradoxical management of his homosexual identity had a deep logic to it. In choosing to lead his double life, Sipple had to calculate the probability

267. See Sipple, 201 Cal. Rptr. at 666.

268. See id. at 667.

269. Id.

270. See id.

271. See id. at 668.

272. See id. at 669 .

273. Id.

274. See id.

275. See id. 
that his activities in San Francisco would come to the attention of his family, multiply that probability by the great harm he would suffer if discovered, and weigh that product against the benefits of his activism. Given that he probably could intuit the likely reaction of his family and the possible benefits of his activism, the crucial variable that Sipple had to estimate was the likelihood that his family would discover his homosexuality. Sipple appears to have assumed that news of his political advocacy was unlikely to travel beyond the community in which he was active. Sipple banked on the fact that the readership of Data Boy, Pacific Coast Times, and Male Express was unlikely to be the same as the readership of the San Francisco Chronicle. 276 This was not an irrational assumption. Not only does the "mainstream" population distance itself from the discrete and insular population of out gays, but "gay-friendly" persons often protect the privacy of gays. ${ }^{277}$ The closet from which one emerges when one comes out to the gay community can be seen as nested within the closet that one emerges from when one comes out to the larger community. It is precisely this distinction between the two kinds of disclosure-one to the "gay-friendly" public and one to the "general" public-that the court overlooked when it stated that "the articles in question did no more than give further publicity to matters which appellant left open to the eye of the public."278 The first public the court mentions is the "general" public, while the second is the "gay-friendly" public. In presenting the former as a simple extension of the latter, the court mistakes a distinction in kind for one of degree.

It is certainly true that Sipple's case tests the boundaries of that distinction, given that he arguably held himself out as gay to the "general" public as well as the gay one by, for example, marching in parades. ${ }^{279}$ Yet

276. See id.

277. Sedgwick's presentation of the story of Poweli's gay clerk as a hypothetical is one example of this, as is Jeffries's (and for that matter my) decision not to name the clerk. See supra note 141 and accompanying text.

278. Sipple, $201 \mathrm{Cal}$. Rptr. at 669 (emphasis added).

279. But even this is open to debate. Evidence for the proposition that gays perceive the "gay" public to be distinct from the "general" public precisely in the way that Sipple did can be found by going to any gay pride parade and watching how the marchers respond to television cameras. Stationary cameras are often trained on the marchers as they pass, and many marchers will avert their faces as they march by these cameras. Again, this seems like a contradiction. Marchers in gay parades are engaged in a "public" act of asserting their support for gays such that television coverage giving "further" publicity to the act should not be a cause for their concern. Indeed, as the marchers presumably intend to demonstrate public solidarity with gays, one might legitimately expect that further publicity would be welcome. That this is not the case indicates that the marchers are drawing a distinction between the two publics to which they are making their statement. The public comprised of persons physically present at the parade, whether as marchers or onlookers, is being distinguished from the more general public that may catch the parade on television. That distinction seems sensible. After all, those who march in or who come out to watch gay-pride parades (with the exception of protestors and some persons who accidentally happen on it) are generally those who are sympathetic to gays. Marchers can thus sustain a legitimate expectation that their disclosure of solidarity will not lead (at least 
the court's analysis would have been more subtle and accurate if it had recognized the distinction before noting that Sipple had eroded it. It would also have been more just, because that distinction is clearer in the lives of many gay people. A court that regards the "public" as monolithic, such that a single disclosure by a gay person of his or her homosexuality can be seen as potentially leaving that person's homosexual identity open to all, puts additional pressure on gays to keep their identities totally secret.

The Coors court also faced the problem of how to balance a person's right to keep his or her homosexuality private with another person's right to know and disclose it. ${ }^{280}$ Coors, a brewery, had entered into a contract with KQED, a public television station in the San Francisco bay area. ${ }^{281}$ Coors alleged that Harold Wallace and the organization Solidarity, a political group comprised solely of gay men and lesbians of which he was a member, had tortiously interfered with the contract by dissuading the station from fulfilling its contractual obligations. ${ }^{282}$ Coors, the plaintiff, sought to discover the names of the membership of Solidarity, which Solidarity refused to give up on the ground that such a disclosure would chill its associational privacy or freedom of political expression under the First Amendment. ${ }^{283}$ The magistrate judge who initially heard the case rejected this defense and ordered Solidarity to answer the interrogatories regarding its membership. ${ }^{284}$ As quoted by the district court, the magistrate judge stated: "I really can't buy the First Amendment claims. I don't find the chilling effect and I don't really see in these papers a solid basis that would support the grounds on which you [Solidarity] object to those interrogatories." 285

The district court's opinion attempted to show the magistrate judge what he could not see. It noted that determining whether a constitutional defense should pre-empt a discovery request necessarily entailed a complicated weighing of interests, which it was not convinced that the judge had undertaken. ${ }^{286}$ In particular, it chastised the magistrate judge for not considering the effects of the closet:

We note that, although Solidarity filed affidavits as to some avowed members' experience with "coming out of the closet," in various professional and social settings, the Magistrate rebuked Solidarity's attempted analogies to prejudicial treatment of

directly) to negative repercussions. In sharp contrast, marchers cannot sustain a similar expectation of television viewers, who may happen upon the gay pride parade while channel surfing.

280. See Adolph Coors Co. v. Wallace, 570 F. Supp. 202, 205 (N.D. Cal. 1983).

281. See id. at 204.

282. See id.

283. See id.

284. See id.

285. Id. at 205 n.5 (quoting Reporter's Transcript, Dec. 1, 1982, at 7) (alteration in original).

286. See id. at 205. 
members of the NAACP in the South and in the Black Panther Party in the major Northern industrial cities out of hand. We find this skepticism and curt dismissal inappropriate, in light of the substantial case law which counsels great solicitude for such claims. Indeed, if membership in the Republican Party is deemed inviolably private, then membership in a far less popular, and far more fragile, association should be afforded at least a similar level of protection. ${ }^{287}$

With these and other comments on the closet, the court emphasized the importance of the closet to a consideration of the privacy interests of gays. The Coors court implied that the magistrate judge should expand the contours of his discussion of the discovery rule to incorporate "softer" forms of evidence, such as the "coming out" stories of gay men and lesbians. ${ }^{288}$

These cases have clear shortcomings in making the point that an explicit discussion of the closet will effect pragmatic changes in the Equal Protection discourse surrounding gays. That one court was insensitive to the privacy rights of gays and did not consider the closet, while another court showed deeper sensitivity to those privacy rights and explicitly considered the closet, is not to say that the closet analysis necessarily accounts for the difference in outcome. Correlation is not causation; even if it were, it would be unclear which way the causation would run. After all, it could be the greater sensitivity to gay privacy rights that incited the discussion of the closet rather than vice versa.

The point, however, is still worth making, in order to suggest that my abstract analysis of the closet symbol may be concretely tethered to judicial outcomes. In both Sipple and Coors, the rule of law at issue was ostensibly neutral on its face. The Sipple court operated on a premise of neutrality, implicitly finding that the rule should not be group sensitive. Thus, it suggested that the efforts of a person attempting to maintain a public and private identity should not be protected even where there were valid motives particular to his group for doing so. The Coors court rejected that premise of neutrality, emphasizing that civil suits (and specifically the ostensibly neutral discovery rules used therein) could be used as "coercive devices to cripple, or subdue, vocal opponents,"289 and noting that the need of many gays for anonymity makes them peculiarly vulnerable in this regard. The Coors court recognized that to allow the discovery motion could, in essence, end the case, as avoiding forced disclosure might be worth more to the defendants than defending the suit. Even a conservative approach to these cases shows that to overcome a court's default presumption that neutrality means applying rules against

287. Id. at 209 n.24 (citation omitted).

288. Cf. Baker v. Wade, 553 F. Supp. 1121 (N.D. Tex. 1982) (giving detailed narrative of gay plaintiff's struggle with his sexual identity), rev'd en banc, 769 F.2d 289 (5th Cir. 1985).

289. Coors, 570 F. Supp. at 209. 
all groups in the same way, one must make a credible case for why true neutrality (insofar as it exists) means treating groups differently. The closet makes that case.

Another challenge to the relevance of these cases is that they concern the privacy rights of gays rather than their political powerlessness, and that it is the latter, rather than the former, that is relevant to their Equal Protection claims. This objection is much more easily overcome, for in each case, the political repercussions of the privacy analysis form an implicit or explicit corollary of the court's discussion. Implicit within Sipple is the understanding that Sipple's political advocacy was held hostage by the closet. As active as he was in San Francisco, his political activity would be conscribed to those communities that would not endanger his closeted status in other communities. ${ }^{290}$ The Coors court made that connection explicitly:

[W] recognize that protecting Solidarity's members from being "plucked" involuntarily from the closet may be necessary to preserving them, as a "discrete and insular minority," within the political process. Justice Stone concluded, in a footnote which has set the tone for the Supreme Court's consideration to all threats to the exercise of minorities' constitutional rights, that the greatest solicitude should be paid to those threats aimed at suppressing an attempted exercise of political rights. Homosexuals attempting to form associations to represent their political and social beliefs, free from the fatal reprisals for their sexual orientation they anticipate in jobs or other social activities, are just such a minority. ${ }^{291}$

The Coors court's dictum exemplifies the tight connection between the personal and the political, revealing that the "personal" privacy issue of non-disclosure might have "political" repercussions deserving of Carolene Products concern.

\section{IMMUTABIITTY AND THE BODY}

The third prong of the Equal Protection test inquires whether the characteristic that distinguishes the group is an immutable one. Unlike the other two prongs of the test, the legitimacy of this entire prong (as opposed to particular formulations of it) in the Equal Protection inquiry has been challenged. Commentators have explicitly, and I believe rightly, called for the retirement of the prong, and some courts have implicitly withdrawn or finessed it. My approach in this Part differs from the ap-

290. Sipple's decision to sue after his family learned of his homosexuality is consistent with the hypothesis that it was his family that was the greatest impediment to his universal avowal of his homosexual identity. By bringing suit, Sipple guaranteed further disclosure (and memorialization of his sexual orientation in law reviews for years to come). Presumably, this additional publicity did not matter because the greatest harm had already been done.

291. Coors, 570 F. Supp. at 209 n.24 (citing United States v. Carolene Prods. Co., 304 U.S. 144, 152 n.4 (1938)). 
proach I take in the two preceding ones in that 1 use the symbol in order to challenge the doctrinal inquiry rather than to answer it.

There are two justifications for why a group must be defined by an immutable characteristic before it is accorded heightened scrutiny. The first is that immutability is a proxy for status-based discrimination, given that immutable characteristics are perceived to be beyond the control of individuals. The second is that immutability can be a proxy for einpathy failure, given that people who know they will never have a characteristic are less likely to empathize with those who do. While both justifications must be assailed before one can properly call for the retirement of the prong, I focus on the second. I do so because, as I will briefly summarize, the first has already been soundly and rightly attacked, while the second, although similarly flawed, has not. I do so also because I believe the empathy-failure framework properly undergirds Equal Protection analysis.

This raises the question of why I seek to reject the second justification (and the entire prong). The symbol of the body answers that question. While immutability may sometimes be a proxy for empathy failure, at other times it is not. An examination of how the body is deployed in the gay context shows that homosexuality is one of the cases in which immutability provides a poor proxy for empathy failure. Indeed, in the case of gays mutability is a better proxy for empathy failure than immutability. This is reflected in anti-gay deployment of the body, in which persons obviously suffering from empathy failure for gays use the body to quiet their fears about the mutability of sexual orientation. It is also seen in pro-gay deployment of the body, in which persons who are not suffering empathy failure for gays often use the body to make arguments that homosexuality is immutable. In both these cases, empathy failure is linked to mutability, and empathy is linked to immutability, via the symbol of the body.

\section{A. Immutability}

1. The Status Justification. - The first justification for the immutability requirement is that immutability helps identify groups that are experiencing status-based discrimination. The immutability prong has traditionally rested on this justification. The Supreme Court introduced this prong in Frontiero by noting that discrimination on the basis of sex classifications "would seem to violate "the basic concept of our system that legal burdens should bear some relationship to individual responsibility."'292 According to Janet Halley, the Frontiero opinion foreshadowed the later problems the Court would have with the status theory of immutability by noting that many classifications based on immutable characteristics, such as intelligence and physical disability, were unproblematic. ${ }^{293}$ Immutabil-

292. Frontiero v. Richardson, 411 U.S. 677, 686 (1973) (quoting Weber v. Aetna Cas. \& Sur. Co., 406 U.S. 164, 175 (1972)).

293. See Halley, supra note 8, at 507-08 (citing Frontiero, 411 U.S. at 686). 
ity was thus not a per se bar, and the prong could be waived if relevance to a legitimate purpose was shown. Given that a statute must have a "legitimate purpose" to survive even rational review, however, the exception seems to engulf the rule. Halley quotes Ely's argument that this reliance on "relevance to a legitimate purpose" in addition to the immutability criterion swallows the immutability factor whole:

[C] lassifications based on physical disability and intelligence are typically accepted as legitimate, even by judges and commentators who assert that immutability is relevant. The explanation, when one is given, is that those characteristics (unlike the one the commentator is trying to render suspect) are often relevant to legitimate purposes. At that point, there's not much left of the immutability theory, is there?294

Halley then describes the lackluster reception that immutability got from the Clebume Court. ${ }^{295}$ The Clebume Court, quoting the Ely passage above, noted that the mentally retarded are "different, immutably so, in relevant respects" from others, but did not infer the need for heightened scrutiny from this difference. ${ }^{296}$ As Halley concludes, "[a]fter Cleburne immutability remains a factor, but it is not clear that the Court will ever again make even an asymptotic approach to a claim that discrimination based on a characteristic the bearer cannot shed is intrinsically repellent to any 'basic concept of our system."'297

Judge Norris's opinion in Watkins v. United States Army, which contains the most recent extended discussion of the inmutability prong, corroborates Halley's account. ${ }^{298}$ In that opinion, Judge Norris notes that:

Although the Supreme Court considers immutability relevant, it is clear that by "immutability" the Court has never meant strict immutability in the sense that members of the class must be physically unable to change or mask the trait defining their class. People can have operations to change their sex. Aliens can ordinarily become naturalized citizens. . . . At a minimum, then, the Supreme Court is willing to treat a trait as effectively iminutable if changing it would involve great difficulty, such as requiring a major physical change or a traumatic change of identity. Reading the case law in a more capacious manner, "immutability" may describe those traits that are so central to a person's identity that it would be abhorrent for government to pe-

294. Id. at 508 (quoting Ely, supra note 37 , at 150 (alteration in original) (footnote omitted)). Halley does point out, however, that there is something (although not much) left of the immutability theory-namely that it can act as a tiebreaker in ordering two equally relevant legislative classifications. See id.

295. See id. at 509-10.

296. See City of Cleburne, Tex. v. Cleburne Living Ctr., Inc., 473 U.S. 432, 442 (1985).

297. Halley, supra note 8 , at 510 (quoting Frontiero, 411 U.S. at 686 (quoting Weber, 406 U.S. at 175)).

298. See 847 F.2d 1329, 1347 (9th Cir. 1988), vacated en banc, 875 F.2d 699 (9th Cir. 1989). 
nalize a person for refusing to change them, regardless of how easy that change might be physically. Racial discrimination, for example, would not suddenly become constitutional if medical science developed an easy, cheap, and painless method of changing one's skin pigment. ${ }^{299}$

Judge Norris's admission that he is reading the case law more capaciously is perhaps an understatement. "Immutability" under his reading has nothing to do with whether something can change, but rather with how important a characteristic is to the possessor's identity. Even under his more conservative first formulation, immutability does not mean that a characteristic is unchangeable, but only that it is difficult to change. In both incarnations, "immutable characteristic" becomes a metonym for "core identity" rather than remaining a synonym for a "characteristic the bearer cannot shed." 300

Based on her review of the judicial treatment of the status theory, Halley criticizes the resurgence of immutability-based arguments among gay-rights advocates. Halley notes that while the "folk" wisdom of saying that one cannot help one's homosexuality "often is the only effective resource available to gay men, lesbians, and bisexuals seeking to persuade their parents, coworkers, and neighbors that they can love someone of the same sex and reinain fully human," 301 it suffers from multiple defects as a constitutional argument, notably that it excludes from its protection those who cannot or will not assert that their homosexuality is immutable. ${ }^{302}$ She concludes that gay-rights litigators should "cease and desist" from invoking strong essentialist arguments about homosexuality. ${ }^{303}$

299. Id. (citing Tribe, supra note 39). Tribe notes that "even if race or gender became readily mutable by biomedical means, I would suppose that laws burdening those who choose to remain black or female would properly remain constitutionally suspect." Tribe, supra note 39 , at 1073 n.52. This response has a certain force, given that it seems inconceivable that such a biomedical procedure would alter our belief that these groups merit heightened scrutiny. Yet there are at least three reasons why Tribe's hypothetical is a false rescue. First, we may recognize a group's reliance interest in the largesse we have extended to it (or develop a reliance interest of our own in that largesse) such that we will not recant a decision that we might make differently if confronted with it de novo. Second, we might recognize that the social meanings that pre-date the technological development will still have binding force after that development, such that, for example, our understanding that an individual's sex is stable over time will endure as a prescriptive maxim that sustains its own reality even when it has lost its descriptive necessity. Third, what Tribe does for immutability may be done for the historical ability to vote and to invisibility as well. While this might appear to be a strength, it actually reveals a weakness. We may not demur when any one characteristic is withdrawn through this hypothetical exercise, but at some point we will balk when enough of these bases for distinguishing between groups currently deemed worthy and unworthy of heightened scrutiny are called into question.

300. Halley, supra note 8 , at 510 .

301. Id. at 567.

302. See id. at 519-20.

303. See id. at 516. 
2. The Empathy-Failure Justification. - While cogent, Halley's critique of the argument from immutability is incomplete, insofar as it only addresses the status theory of immutability. After considering and critiquing the status theory, ${ }^{304}$ Ely points out a more viable alternative:

[M] utability (or something like it) may be relevant in another way as well, one that bears on the likelihood that the decisionmaker's ability to generalize will be distorted by his or her perspective. For example, it is at least arguable that the facts that all of us once were young, and most expect one day to be fairly old, should neutralize whatever suspicion we might otherwise entertain respecting the multitude of laws (enacted by predominantly middle-aged legislatures) that comparatively advantage those between, say, 21 and 65 vis-à-vis those who are younger or older. It is not quite the same thing as immutability, of course: alienage generally is an escapable condition, so in theory are poverty and perhaps even gender. But nonetheless, and it is this that seems more relevant, most legislators have never been alien, poor, or female. They all were young, though, a fact that may enhance their objectivity about just what the difference entails. 305

Ely thus tries to harmonize the immutability prong with his now-familiar empathy-failure theory of the Clause. Under this formulation, immutability stands as a proxy for groups that may be victims of empathy failure on the part of the legislature. That a legislator might share a given characteristic has the effect of psychologically internalizing the costs of any legislation that will burden the group with that characteristic. If a characteristic is immutable, however, the legislator who does not share that characteristic is less likely to sympathize in this way. ${ }^{306}$

304. See Ely, supra note 37 , at 150 .

305. Id. at 160 (footnotes omitted).

306. An interesting comparison might be made with the theory of the "original position" outlined in John Rawls, A Theory of Justice (1971). Rawls's processual theory of fairness also considers the dangers of empathy failure:

The idea of the original position is to set up a fair procedure so that any principles agreed to will be just. The aim is to use the notion of pure procedural justice as a basis of theory. Somehow we must nullify the effects of specific contingencies which put men at odds and tempt them to exploit social and natural circumstances to their own advantage. Now in order to do this I assume that the parties are situated behind a veil of ignorance. They do not know how the various alternatives will affect their own particular case and they are obliged to evaluate principles solely on the basis of general considerations.

Id. at 136-37 (foomotes omitted). Rawls, like Ely, realizes the danger that "the decisionmaker's ability to generalize will be distorted by his or her perspective." Ely, supra note 37, at 160. He therefore creates the original position as a hypothetical situs in which decisionmakers bracket the characteristics that might distort that perspective. Under Ely's formulation, the immutability prong makes a less radical inquiry: it controls for distortions of perspective not by asking decisionmakers hypothetically to surrender those characteristics, but merely by asking them to be alert to their potentially distortive nature. The underlying thrust of both positions, however, is similar-both press decisionmakers to identify and compensate for characteristics that are known to lead to empathy failure. 
Unlike the status justification, this justification conforms to the empathy-failure theory of the Equal Protection Clause. By doing so, it resolves the tension that some commentators have seen between the immutability prong and the other two prongs of the test. This tension can be characterized as one between the symmetrical and the asymmetrical treatment of groups. Any immutable characteristic will generate at least two groups: a group that will always have that characteristic and a group that never will. The status justification of the immutability prong treats these groups symmetrically-that is, if one group gets heightened scrutiny under this prong, then the other group must as well. It can hardly do otherwise, since it focuses on the injustice of burdening immutable status, and each group is locked into an immutable status. Thus, because both men and women are marked by the immutable characteristic of their sex, ${ }^{307}$ discrimination leveled against men is just as impermissible as discrimination leveled against women. But this symmetrical treatment of groups conflicts with the asymmetrical treatment of groups under both the history prong and the political-powerlessness prong. Faced with two groups, both the history prong and the political-powerlessness prong direct solicitude toward the more disempowered group.

When courts resolve the tension that inheres in the Equal Protection test in favor of the symmetrical approach, things happen that seem at odds with a Carolene Products reading of the Clause. Once a disfavored group passes this prong, the favored group from which the immutable characteristic separates it must also pass. This ultimately may lead both favored and disfavored groups to get protection. As Justice Rehnquist noted in his dissent in Craig $v$. Boren, the courts treat "gender classification as a talisman which-without regard to the rights involved or the persons affected-calls into effect a heavier burden of judicial review."308 Justice Rehnquist found this puzzling in light of the fact that men did not meet the indicia of a suspect class. ${ }^{309}$ Moreover, as seen in the affirmative action context, measures purporting to help the disfavored groups often will get struck down on the basis of symmetry. ${ }^{310}$ This leveling aspect of

307. Of course, as Judge Norris points out, gender is not strictly immutable. See Watkins v. United States Army, 847 F.2d 1329, 1347 (9th Cir. 1988), vacated en banc, 875 F.2d 699 (9th Cir. 1989).

308. 429 U.S. 190, 220 (1976) (Rehnquist, J., dissenting).

309. As Justice Rehnquist noted:

Most obviously unavailable to support any kind of special scrutiny in this case, is a history or pattern of past discrimination, such as was relied on by the plurality in Frontiero to support its invocation of strict scrutiny. There is no suggestion in the Court's opinion that males in this age group are in any way peculiarly disadvantaged, subject to systematic discriminatory treatment, or otherwise in need of special solicitude from the courts.

Id. at 219 (Rehnquist, J., dissenting).

310. See, e.g., Adarand Constructors, Inc. v. Pena, 115 S. Ct. 2097, 2114 (1995) (holding that racial classifications imposed by federal law, even to remedy general past discrimination, must be subjected to strict scrutiny); Hopwood v. State of Texas, 78 F.3d 932, 940 (5th Cir.), cert. denied, 116 S. Ct. 2581 (1996) (reaching similar conclusion). 
the test is out of keeping with the Carolene Products-based theory of protecting disempowered groups.

The empathy-failure theory of immutability resolves this tension. In sharp contrast to the status theory, it treats the two groups differentiated by an immutable characteristic in an asymmetrical way that is consistent with the other two prongs. This is because, as Ely points out, immutability per se is not the real issue, but rather serves as a proxy for empathy failure. ${ }^{311}$ The inquiry, then, looks at how the group is situated in society rather than merely at how the trait is situated in the individual. If empathy failure is the driving concern, the treatment of the two groups need not (and indeed, will not) be symmetrical. Thus, in the same example of sex distinctions, men can be treated differently from women because men are not likely to bear the brunt of such empathy failure. The empathy-failure theory thus harmonizes the three prongs of the test.

The Court could look to this more coherent empathy-failure theory of immutability to resuscitate its analysis. Yet this would be problematic. Like the status theory, the empathy-failure theory of immutability is vulnerable, because immutability is a poor proxy for empathy failure. In certain cases, mutability engenders more empathy failure than immutability, and homosexuality constitutes one of these cases. For this reason, the immutability prong should be jettisoned from the Equal Protection inquiry, unless another theory for its usefulness proves viable.

Ely concedes that immutable characteristics are not perfect proxies for those traits that cause empathy failure: "It is not quite the same thing as immutability, of course: alienage generally is an escapable condition, so in theory are poverty and perhaps even gender."312 Moreover, Ely's proffered evidence ${ }^{313}$ as to why mutability may occasion more empathythe instance of age-may not do as much work for him as it initially seems. Ely is not alone in perceiving that age is a characteristic that does not necessarily have to divide political groups. ${ }^{314}$ Yet even assuming that this is true, ${ }^{315}$ it is not clear that it is the mutable aspect of age that is

311. See Ely, supra note 37, at 160.

312. Id.

313. See id. at 160 \& n. 82 .

314. See Peter H. Schuck, The Graying of Civil Rights Law: The Age Discrimination Act of 1975, 89 Yale L.J. 27, 33 (1979) (noting that age is an attribute "that each of us presumably has experienced or will experience; members of other age groups are surely less likely to use age rules to oppress persons whose status they have shared or expect to share") (citation omitted).

315. I think this is presumptively, but not necessarily, true. First, distinctions should be made between ages that legislators have been and ages legislators will be. One could argue that legislators will be more likely to impose burdens on those younger than they are because those burdens are unlikely to affect them. More generally, legislators may not experience sympathy for either group if the group appears unlike the group they were or will be at that age. Viewing the moral decay in the younger generation, a legislator might feel more alienated from that group than otherwise precisely because he will contrast members of that generation with (his recollection of) the morally upstanding youth he was at the same age. The fact that "he was there" may allow him a kind of moral authority that 
maintaining political empathy. After all, while age is a mutable factor, aging is immutable, so there is a critical problem of initial definition. In addition, it may be the universality of aging, rather than the mutability of age, that makes it unlikely to generate empathy failure. Even immutable characteristics will not create empathy failure if they are universal-think about the need to breathe.

Indeed, there are certain situations in which mutability would seem to occasion more empathy failure than immutability. The empathy-failure theory rests on the correct and commonsensical premise that if a characteristic is mutable, it is more likely to implicate the decisionmaker who does not share that trait. It mistakenly assumes, however, that complicity inevitably will lead to greater empathy. In some cases, it may indeed be true that complicity leads to empathy-"He that is without sin among you, let him first cast a stone," 316 Jesus says, and the adulteress is saved because the townspeople are convicted by their own consciences of their complicity in her sin. Yet in other cases, it is precisely because the decisionmaker is implicated that he experiences a visceral antipathy toward a group.

Class can exemplify a mutable characteristic that creates such antipathy. As Barbara Ehrenreich notes, it is not in spite of, but because of, the fact that the middle class of the 1960s saw their potential to change into the poor that they needed to distance themselves from the lower class. ${ }^{317}$ Ehrenreich posits that the poor were "invented" in that period, by which she means that they were demonized as "half-child, half-psychopath" in order to represent what the middle class feared most in itself, a "softening of character [and] lack of firm internal values." ${ }^{318}$ This invention served the middle class because, with "the discovery of poverty, the threat could be externalized: Someone else had succumbed to the softening effects of the consumer culture." ${ }^{319}$ Difference defined was identity affirmed; by projecting the repressed and feared potentialities of the self onto a person describable as the other, the middle class self assuaged its own fears. Yet those fears could be quieted only so long as the other remained the other, so long as the commonalities due to mutability remained carefully obscured by protestations of difference. One form that "protesting too much" took was demonization and antipathy.

To show that homosexuality works in precisely this way, I look at how immutability is deployed both by pro-gay and anti-gay activists. Whether

he would not choose to claim had the characteristic been one that he had not shared. Similarly, if a legislator knows that current senior citizens are enjoying benefits-such as Social Security-that he likely will not enjoy at the same age, he may feel more alienated from them, especially if it is their enjoyment of the benefits that deprives him of his.

316. John 8:7.

317. See Barbara Ehrenreich, Fear of Falling: The Inner Life of the Middle Class 17-56 (1989).

318. Id. at 51 .

319. Id. at 52-53. 
consciously or not, this debate about sexual orientation has been played out on the body. ${ }^{320}$ By examining how pro-gay and anti-gay activists deal with the body as a metaphor for what is fixed about us, we can show that inutability increases einpathy failure for gays while immutability decreases it.

\section{B. The Body}

The body is a cominon symbol. We see it in many formulations: body of water, body of knowledge, body politic, Congressional body, body of evidence, eucharistic body. Indeed, the process of making metaphors is itself described as a process of making bodies, a process of embodiment or figuration. The unique metaphorical value of the body, as indicated in these examples, lies in its distinctiveness and fixity. First, the body appears to be distinctive-there are clear boundaries between what is the body and what is not the body. Second, it appears to be fixed-not perfectly, but reasonably, stable over time.

Unlike the pink triangle and the closet, the body has not been selfconsciously deployed as a gay symbol. Nevertheless, the body has been relentlessly (albeit inostly unthinkingly) used as an emblem of the distinctiveness and fixity of homosexuality for both pro-gay and anti-gay persons. It is important to remember that this need not be so. As Carol Warren has noted: "Logically, homosexuality refers to a type of behavior rather than to a condition. However, homosexuals are viewed generally not just as people who do a certain type of thing, but, rather, as people who are a certain type of being."321 While every time we speak of a person as a "homosexual" the body undergirds that statement, there are inore specific demarcations as well. Gay bashers deploy the gay body as an embodiment of homosexuality, like an allegorical figure in a inedieval morality play, for the purposes of wreaking violence upon it. Pro-gay activists also deploy the gay body, but to the opposite effect. By emphasizing the body as an emblem of what is fixed about an individual, they emphasize the immutability and, therefore, the inoral neutrality of sexual orientation.

1. Homophobic Deployments of the Body. - Kendall Thomas notes that a distinctive aspect of homophobia is the frequency and severity of the violence it exacts on hoinosexual bodies. Shortly after Bowers was decided, a study commissioned by the National Institute of Justice noted that gay inen and women "are probably the most frequent victims [of hate violence today]."'322 A New York City hospital reported that "'attacks against

320. See Halley, supra note 8 , at 516-17 (describing pro-gay and anti-gay deployments of immutability).

321. Carol Warren, Homosexuality and Stigma, in Homosexual Behavior: A Modern Reappraisal 123, 124 (Judd Marmor ed., 1980).

322. Thomas, supra note 2, at 1464 (quoting Peter Finn \& Taylor McNeil, The Response of the Criminal Justice System to Bias Crime: An Exploratory Review 2 (1987)) (alteration in original). Thomas also notes that: 
gay men were the most heinous and brutal ... encountered," and "frequently involved torture, cutting, mutilation, and beating, and showed the absolute intent to rub out the human being because of his [sexual] orientation." 323 Thomas further notes that this violence often does not stop at killing the victim:

One study of homophobic murders found that in most instances, the victims were not just killed, but were "more apt to be stabbed a dozen or more times, mutilated, and strangled, . . . [and] [i]n a number of instances, ... stabbed or mutilated even after being fatally shot." The characteristic "overkill and excessive mutilation" of attacks on gay men and lesbians suggest that this is a species of violence whose form conveys its expressive content: the medium is the message. ${ }^{324}$

One might expect that the advent of AIDS would force such expressions of violence to take less bodily invasive forms because of the risk of infection, but statistical evidence has shown a positive correlation between AIDS and a rise in physical violence against gays. ${ }^{325}$ This homophobic obsession with violating the body through direct bodily contact makes it seem as if the body is one of the most useful means through which to attack homosexuality. The lesson of the body that needs to be stabbed even after such stabbings have rendered it a corpse is that homosexuality, like a disease, may leave its traces in the body even after life has passed out of it; the lesson of bashings which risk the basher's lives for the privilege of bodily violence is that this risk is trumped by the literal need for homosexual blood.

This evidence of the relationship between homophobia and the homosexual body might seem to support the contention that empathy fail-

[I]t is estimated that a full $80 \%$ of bias violence against gay men and women is never reported to the police. This under-reporting is not surprising, since victims of anti-gay violence have reason to be fearful that the response of state and local officials may be unsympathetic or openly hostile, or that the disclosure of their sexual orientation may lead to further discrimination.

Id. at 1464 (citation omitted).

323. Id. at 1463 (quoting National Gay and Lesbian Task Force, Anti-Gay Violence, Victimization and Defamation in 1988, at 8 (1988)) (alteration in original).

324. Id. at 1466-67 (citing Gary D. Comstock, Violence Against Lesbians and Gay Men 46-47 (1991) (quoting Brian Miller \& Laud Humphreys, Lifestyles and Violence: Homosexual Victims of Assault and Murder, 3 Qualitative Soc. 169, 179 (1980))) (alteration in original).

325. As Sedgwick notes:

A similar phenomenon, also too terrible to be noted as a mere irony, is how evenly our culture's phobia about HIV-positive blood is kept pace with by its rage for keeping that dangerous blood in broad, continuous circulation. ... [M] ost immediately and pervasively [this] is evidenced in the literal bloodbaths that seem to make the point of the AIDS-related resurgence in violent bashings of gays-which, unlike the gun violence otherwise ubiquitous in this culture, are characteristically done with two-by-fours, baseball bats, and fists, in the most literal-minded conceivable form of body-fluid contact.

Sedgwick, supra note 131, at 129. 
ure is related to immutability, for the insistence of gay-bashers on the body implies that homosexuality has a fixed seat in the body. But these are also the persons who are least likely to adhere to the immutability theory of homosexuality, given that this theory exonerates gays from moral culpability. ${ }^{326}$ The fixity that the body ensures for homophobes, therefore, is less immutability than what Foucault has called a "perverse implantation." 327 Under Foucault's theory, homosexuality is implanted in a body in a stable enough way to provide an embodiment that may be attacked, but does not permeate the individual so deeply as to provide the absolution of immutability.

Perverse implantation is a complicated act of social legerdemain, insofar as it must simultaneously assert that something is neither completely mutable nor immutable: a status at once defined by a choice to engage in certain conduct, but that also stands apart from that conduct. This legerdemain is at work in the odd ability of a community to distinguish between its designated homosexuals and those engaged in homosexual acts. In the Nazi death camps, homosexuals were marked by pink triangles; many guards, however, engaged in homosexual acts without being branded in this way. ${ }^{328}$ Similarly, in the military, the single statement "I am a homosexual" stands as the equivalent of the pink triangle insofar as it marks a person as homosexual even in the absence of known homosexual conduct, ${ }^{329}$ while, at the same time, a person can perform homosexual acts that do not result in the nomenclature of homosexual being at-

326. See Halley, supra note 8 , at 518 n.62 (citing surveys that note correlation between belief that homosexuality is immutable and disapproval of discrimination against gays).

327. Michel Foucault, 1 The History of Sexuality: An Introduction (Robert Hurley trans., 1990). The homosexual body as a metaphor has been explored through Foucault's concept of the perverse implantation. As Foucault frames it in a celebrated quotation, "homosexual" as an adjective was used to modify acts, not persons, until the late nineteenth century, when a paradigm shift occurred:

As defined by the ancient civil or canonical codes, sodomy was a category of forbidden acts; their perpetrator was nothing more than the juridical subject of them. The nineteenth-century homosexual became a personage, a past, a case history, and a childhood, in addition to being a type of life, a life form, and a morphology, with an indiscreet anatomy and possibly a mysterious physiology. Nothing that went into his total composition was unaffected by his sexuality. It was everywhere present in him: at the root of all his actions because it was their insidious and indefinitely active principle; written immodestly on his face and body because it was a secret that always gave itself away. . . . Homosexuality appeared as one of the forms of sexuality when it was transposed from the practice of sodomy onto a kind of interior androgyny, a hermaphrodism of the soul. The sodomite had been a temporary aberration; the homosexual was now a species.

Id. at 43 .

328. See Plant, supra note 121, at 169-71.

329. See Steffan v. Cheney, 780 F. Supp. 1, 5 (D.D.C. 1991), rev'd on other grounds sub nom. Steffan v. Aspin, 8 F.3d 57 (D.C. Cir. 1993), rev'd en banc sub nom. Stefan v. Perry, 41 F.3d 677 (D.C. Cir. 1994). 
tached to that person. ${ }^{330}$ We clearly need to have people we can call homosexuals, even when the conduct that ostensibly defines them as such proves under- and over-inclusive as a means of distinguishing them.

It is imperative to recognize, however, that while perverse implantation may seem to have elements of both mutability and immutability, the driving force behind it lies in the mutability of homosexuality. Iris Marion Young notes: "Homophobia is one of the deepest fears of difference precisely because the border between gay and straight is constructed as the most permeable; anyone at all can become gay, especially me, so the only way to defend my identity is to turn away with irrational disgust." 331 To recognize that one might be gay is an incitement to engage in the form of protesting too much that is the implantation of homosexuality in another. As argued earlier, the closeted homosexual is likely to be the one who most vehemently needs to distance himself from homosexuality. How better for him to break the continuum between homosexuality and heterosexuality than by dichotomizing it into homosexual and heterosexual bodies? 332

Mutability explains the strange disjunction between status and conduct noted above. For if the need to implant homosexuality arises out of the need to create an other out of the ostensibly exorcised possibilities within the homophobic self, then it stands to reason that those possibilities (insofar as they cannot truly be exorcised) can find fuller expression once that other is created. The existence of a branded homosexual or an "avowed" homosexual makes it easier for "straights" to engage in homosexual conduct, because it transforms a distinction of degree (of homosexual conduct) into a distinction in kind (between gay and straight bodies demarcated by the boundaries of skin). ${ }^{333}$ The constitution of

330. See, e.g., William N. Eskridge, Jr., Gay Legal Narratives, 46 Stan. L. Rev. 607, 627-29 (providing examples of homoerotic conduct in the military that does not result in soldiers being labeled homosexual).

331. Iris M. Young, Justice and the Politics of Difference 146 (1990). The fact that the act of sex traditionally has been conceived as one in which bodies are merged heightens the perceived threat of the homosexual body. The angels in Paradise Lost are contrasted to mere mortals because for them sexual congress is one of perfect blending. John Milton, Paradise Lost, Book VIII, 11. 626-29 ("if Spirits embrace, / Total they mix, union of pure and pure / Desiring, nor restrained conveyance need / As flesh to mix with flesh, or soul with soul"). Yet even in crude mortal acts of sex, the boundaries of the body are temporarily extended in a way that may be unique in human experience. Sexual orientation, because it has no visible markers, may be called into question precisely through this act of merging. The putative heterosexual who has sex with a homosexual (of the same sex) may, through that act of merging, be "infected" or "revealed" as a homosexual himself.

332. Indeed, the practice of confining the homosexual in the closet merely mimics and completes the antecedent practice of confining homosexuality in the body of the other.

333. See Eskridge, supra note 330, at 626-29 (discussing how the military's labeling of homosexuals as incompatible with military service allows soldiers to engage in homosexual conduct while denying its homoerotic dimensions). This transformation will always be an unstable one because it attempts to convert a continuum into a binary. This is perhaps why 
homosexuals is also the constitution of heterosexuals, ${ }^{334}$ heterosexuals now liberated to engage in homosocial or homoerotic acts that fall short

the word "queer" is the best word for the "homosexual" half of the binary. Sedgwick notes that:

The word "queer" itself means across-it comes from the Indo-European root twerkw, which also yields the German quer (transverse), Latin torquere (to twist), English athwart ... . The queer of these essays is transitive-multiply transitive. The immemorial current that queer represents is antiseparatist as it is antiassimilationist. Keenly, it is relational, and strange.

Sedgwick, Foreword: T Times, in Tendencies, supra note 153, at xi, xii. The word "queer" thus denotes a category on one side of a line, but it is the kind of category that will always be reaching across that line to call into question the dividing practice that drew it.

334. The dividing practice is usually unconscious; the statement: "She is a homosexual" usually is not perceived by the speaker as a manner of saying: "I, on the other hand, am heterosexual." There is, of course, a reason for this blindness, in that the need for "the homosexual" rests in a desire to defend the separation of homosexual and heterosexual from close scrutiny.

This tacit dividing practice is committed by communities in addition to individuals. For example, in Rowland v. Mad River Local School District, Montgomery County guidance counselor Marjorie Rowland was fired for a declaration of her bisexuality precipitated in part by her counseling two homosexual students. See 730 F.2d 444, 446 (6th Cir. 1984). The sexuality of those who would dismiss her, of course, was never explicitly in question. Yet the act of silencing her bisexuality needs to be read, as Janet Halley has read it, as an act of self-fashioning on the part of the community:

Both Rowland and the town of Mad River were engaged in a diacritical struggleone in which the self-definition of both players was at stake. This should make visible what otherwise should remain hidden-Rowland's discursive exertions were made in interaction with a class of heterosexuals also in the process of selfconstitution.

Janet E. Halley, The Construction of Heterosexuality, in Fear of a Queer Planet 82, 85 (Michael Warner ed., 1993). The appellate court, in upholding the school district's termination of Rowland, rejected her Equal Protection claim by stating that she "sought to prevail on her equal protection claim without any showing that heterosexual school employees in situations similar to hers have been, or would be, treated differently for making their personal sexual preferences the topic of comment and discussion in the high school community." Rowland, $730 \mathrm{~F} .2 \mathrm{~d}$ at 451-52. In so stating, the court showed its complicity in occluding the relationship between the self-constitution of the community as straight and the constitution of Marjorie Rowland as deviant. The court implies that there would have been no difference between the furor surrounding Rowland's declaration of bisexuality and the reaction to a hypothetical disclosure of heterosexuality. Yet it is precisely the point of the case, as Justices Brennan and Marshall pointed out in their dissent from the Supreme Court's denial of certiorari, that Rowland's disclosure could not have been the topic of "comment and discussion" but for the fact of her bisexuality. 470 U.S. at 1009 (Brennan, J., dissenting from denial of certiorari). Rowland revealed her bisexuality in response to the question of why she was in a good mood on a particular day by responding that she was having a romantic relationship with another woman. See id. at 1009 n.11. She could not have caused the same stir by revealing her heterosexuality on that occasion because she was incapable of revealing her heterosexuality, as her audience was a community committed to the presumption that all of its members were heterosexual. The intrusion of the inconvenient fact of her bisexuality called that expectation into question. The expulsion of Rowland from the school community counteracted that intrusion. The sanction placed on Rowland was not a judgment rendered by an inert, objective community but a response made by a community in need of reasserting its own normative heterosexuality. 
of their being branded as homosexual themselves. ${ }^{335}$ The homophobic fear that drove the implantation was that the heterosexual would not be able to resist becoming a homosexual; ironically, that fear finds fuller expression once it has been overtly dispelled.

Further evidence that homosexuality engenders anxiety because of its mutability can be adduced by comparing homosexuals to other sexual outliers. We rely on the body to organize our social life by ensuring the fixity of certain traits. One of these traits is obviously sex, whose binary division the body appears to accommodate readily. A corollary of the axiom of "one body, one person" appears to be "one body, one sex." The social interest in this corollary reveals itself in the vehemence with which sexual deviance is defined and regulated by it. What even a cursory review of three sex-based outliers-transsexuals, transvestites, and homosexuals-shows is the strong interest in retaining that premise. Transsexuals violate the corollary by surgically changing from one sex to another, obtaining special knowledge of how it is to operate both as a man and a woman in society. ${ }^{336}$ Transvestites do so by using sartorial means to obtain the same knowledge. ${ }^{337}$ And homosexuals do so by having the biological traits of one sex and the sexual preferences traditionally associated with the opposite one. ${ }^{338}$

While all of these sex-based outliers violate the "one body, one sex" corollary, they are not perceived to violate them equally because the body itself constrains some transgressions more than others. Comparing transsexuals and transvestites, Judge Posner notes that:

$[W]$ e should expect the converted transsexual to engender less shock than the transvestite. (I believe this is true.) Transsexual conversion, requiring as it does surgical and hormonal treatments, is not facile impersonation. It is painful, time-consuming, expensive-and irreversible. Transsexualism does not imply that we can change our sexual identity by changing our clothes. ${ }^{339}$

Transsexualism threatens settled sexual expectations less because it asks more of the body of the person who engages in it. The painful and irreversible dues that must be paid for such a subversion deter all but those

335. See Eskridge, supra note 330, at 626-29.

336. The transgressively plural knowledge of transsexuals has been dubbed the "Tiresias syndrome." See Alison Baker, Better Be Ready 'Bout Half Past Eight, The Atlantic Monthly, Jan. 1993, at 93, 95-96, available in LEXIS, News Library, Arcnws File. It is named after the classical figure who changed from a man to a woman and back again. See Ovid, Metamorphoses 73-74 (Horace Gregory trans., 1958).

337. See generally Marjorie Garber, Vested Interests: Cross-Dressing \& Cultural Anxiety 128-61 (1992) (exploring the relationship between transvestism and gender construction as distinct from homosexuality).

338. Hence the conception of the homosexual (which actually preceded our contemporary notions of homosexuality) as an invert. See Sedgwick, supra note 131, at 87 (discussing conception of invert as a man's soul trapped in a woman's body, or vice versa).

339. Posner, supra note 17 , at 27. 
who have good reasons to engage in it. Transsexualism achieves a kind of moral seriousness because it cannot be a matter of mere play.

In sharp contrast, transvestites are more threatening because the body provides no constraint that prevents a transvestite from confusing sex boundaries. Because the body does not exact such dues from the transvestite, it falls on society to impose them artificially. Stephen Greenblatt gives a wonderful example of how a seventeenth-century court resolved the "transvestite problem":

This was the case of Thomasine Hall, born in the 1570s near Newcastle upon Tyne. At age twelve, Thomasine was sent by her mother to live with an aunt in London, where she remained for ten years. At the time of the Cádiz action, we are told, she cut her hair, renamed herself Thomas, and enlisted as a soldier; then returned to London and resumed her life as a woman; then abandoned her needlework again and sailed as a man to Virginia; then became Thomasme once more and served as a chambermaid. Hauled before the Council and General Court of Virginia in 1629 and asked "why hee went in weomans aparell," Thomasine gave the unforgettable, if enigmatic, reply, "I goe in weomans aparell to gett a bitt for my Cat." The judges evidently felt that unresolved sexual ambiguity was more tolerable than dizzying sexual metamorphosis; they preferred a figure frozen in acknowledged androgyny to one who passed fluidly and unpredictably from one state to another. Accordingly, they ordered that it be published that Hall "is a man and a woman," and they insisted upon this doubleness in the clothes they required him to wear: "Hee shall goe Clothed in mans apparell, only his head to bee attired in a Cyse and Croscloth [?] with an Apron before him." 340

What is interesting about the story is that the court did not seem to find Thomas(ine)'s androgyny as disturbing as her protean ability to shuttle back and forth between the male and the female identity. While the story may have only limited relevance insofar as it is an example (and an anomalous one) ${ }^{341}$ of a colonial treatment of transvestism, it does dovetail with Posner's hypothesis that what may be disturbing about transvestites is the fact that their "dizzying sexual metamorphosis" is simply too "fluid" and "unpredictabl[e]." 342

In this regard, the homosexual is more like the transvestite than the transsexual. Posner notes that the shock occasioned by transvestism and male homosexuality both arise in part out of their protean nature:

[T]he shock value of transvestism and of effeminate or hypermasculine male homosexuality is related to our deep-

340. Stephen Greenblatt, Shakespearean Negotiations 178 n.13 (1988) (citing Minutes of the Council and General Court of Colonial Virginia, 1622-32, 1670-76, at 195 (H. R. McIlwaine ed., 2d ed. 1979)).

341. See id.

342. Id. 
seated anxiety about disguises. To maneuver effectively in the world, we need to assume that people and things have stable identities. The idea that someone might change his identity by changing his clothes violates this assumption. The method is too facile. It is inconsistent with stable expectations. It is as if an old man could pass himself off as young just by dressing like a child. ${ }^{343}$

Because the body does not provide any visible markers of homosexuality, it does not police that identity. ${ }^{344}$ The homosexual body therefore must be constructed through the process of implantation; just as the colonial court sought to "freeze" Hall, the attempt to police homosexuals may arise from the same desire to freeze the homosexual in a given, identifiable body.

2. Pro-Gay Deployment of the Body. - The pro-gay position that homosexuality is immutable is a pre-emptive strike against this argument-it contends that society need not artificially winnow gay from straight because biology has already done so naturally. The pro-gay deployment of the homosexual body is most obvious in medical studies purporting to find different neurobiological factors relating to sexual differentiation that may explain homosexuality. Such studies include those investigating the pattern of cognitive skills, ${ }^{345}$ hemispheric patterns of electrophysiological activation in male homosexuals, ${ }^{346}$ and functional cerebral asym-

343. Posner, supra note 17 , at 26.

344. In comparing transvestites to effeminate and hypermasculine male homosexuals, Posner implies that the body may be refashioned as if it were a kind of clothing. It is important to note that this aspect of the body calls into question its use as a signifier for immutability. Posner is correct: many gays and lesbians do appear to use the body in addition to their clothing as a means of "gender bending" - that is, exaggerating gender cbaracteristics traditionally ascribed to their sex (butch man or femme lesbian) or appropriating the gender cbaracteristics traditionally ascribed to the opposite sex (effeminate man or butch lesbian). See, e.g., Judith Butler, Imitation and Gender Insubordination, in Inside/Out: Lesbian Theories, Gay Theories 13, 18-26 (Diane Fuss ed., 1991); Mary Anne C. Case, Disaggregating Gender from Sex and Sexual Orientation: The Effeminate Man in the Law and Feminist Jurisprudence, 105 Yale L.J. 1, 20-21 (1995); Sue-Ellen Case, Toward a Butch-Femme Aesthetic, in Making a Spectacle: Feminist Essays on Contemporary Women's Theatre, 282, 294-300 (Lynda Hart ed., 1992). A hypermasculine gay man may deploy his muscularity as well as his chaps as part of his selffashioning in the same way that a butch lesbian may use her body hair and combat boots in hers. But if a body may be doffed and donned like clothing, how accurate is it to use it as a proxy for what is fixed about us? Indeed, as Posner indicates, part of the aversion to gays and lesbians may arise from the fact that their deployment of the body calls into question stable social orderings that are implicitly predicated on the assumption that the body is (or should be) immune to such reformulations.

345. See Cheryl M. McCormick \& Sandra F. Witelson, A Cognitive Profile of Homosexual Men Compared to Heterosexual Men and Women, 16 Psychoneuroendocrinology 459, 466 (1991) (discussing correlation between sexual orientation and cognitive abilities).

346. See Joel E. Alexander \& Kenneth J. Sufka, Cerebral Lateralization in Homosexual Males: A Preliminary EEG Investigation, 15 Int'l J. of Psychophysiology 269, 
metry. ${ }^{347}$ Other studies adduce more ocular proof in the fingerable structures of physiology, stating that differences between gays and straights can be found in the anterior commissure of the human brain, ${ }^{348}$ in the hypothalamic structure of the brain, ${ }^{349}$ in DNA markers on the X chromosome, ${ }^{350}$ and in the dermal ridges on fingerprints. ${ }^{351}$ While the anti-gay deployment of the body offers up its blood, the pro-gay deployment offers up its chroinosomes. If homosexuality is immutably part of my body but not yours, then the border between homosexuality and heterosexuality becoines the stable one of my skin, which divides what is me from what is not me.

It is thus no accident that when Nussbaum testified as a pro-gay expert witness before the district court in Evans $v$. Romer, ${ }^{352}$ she focused on Aristophanes's story from the Symposium during the "very short time" she had the ear of the Colorado district court. ${ }^{353}$ Aristophanes gives an account of how inen and women were originally joined at the back. What Aristophanes calls the "male sex" is thus two conjoined men; what he calls the "female sex" is two conjoined women, and what he calls the "third" or "Androgynous" sex is a conjoined woman and man. Broken apart for their hubris, both men and women go about searching for their lost other halves. Those who belonged to the "male sex" and "female sex" are thus attempting to consummate homosexual relationships, while those who belonged to the "Androgynous sex" are thus attempting to consummate heterosexual ones. ${ }^{354}$

While the story works on many levels as a defense of homosexual love, ${ }^{355}$ its primary contribution may be its ability to quiet the homo-

273 (1993) (discussing variable EEG activity between homosexual and heterosexual populations).

347. See Cheryl M. McCormick \& Sandra F. Witelson, Functional Cerebral Asymmetry and Sexual Orientation in Men and Women, 108 Behavioral Neuroscience 525, 527-29 (1994) (discussing study of cerebral asymmetry in gay subjects).

348. See Simon LeVay, The Sexual Brain 123 (1993).

349. See Simon LeVay, A Difference in Hypothalamic Structure Between Heterosexual and Homosexual Men, 253 Science 1034, 1034 (1991).

350. See Dean H. Hamer et al., A Linkage Between DNA Markers on the $\mathrm{X}$ Chromosome and Male Sexual Orientation, 261 Science 321, 321 (1993).

351. See J.A.Y. Hall \& D. Kimura, Dermatoglyphic Asymmetry and Sexual Orientation in Men, 108 Behavioral Neuroscience 1203, 1203 (1994).

352. 882 P.2d 1335 (Colo. 1994), aff'd, 116 S. Ct. 1620 (1996).

353. See Nussbaum, supra note 127 , at 1517.

354. See Plato, Symposium ,30-34 (Benjamin Jowett trans., Bobbs-Merrill Co. 1985).

355. For example, the heterosexual is seen to have its genesis in the "Androgynous sex which partook of male and female in name and appearance, though surviving now only as a name and a name of abuse." Aristophanes's story thus traces the group most privileged by extant norms of sexual orientation-the heterosexual-back to an identity that would be "abused" under the same norms-the Androgyne or hermaphrodite. The story also traces the gay man and the lesbian back to sexes that extant sex norms have deemed more normal一the "male sex" and the "female sex" respectively. Moreover, by positing a symmetry between bodies attached to the same sex and bodies attached to the opposite sex, Aristophanes suggests a symmetry in the legitimate ends of those bodies. 
phobic imagination by positing the immutability of homosexuality. One of the reasons why the reader might be more likely to see how gays might be similarly situated to straights through this story is precisely that those identities are held fundamentally distinct. By positing a scenario in which each of us looks for his or her lost other half (which must be either man or woman) the story makes sexual orientation into the same kind of stable binary as sex.

Moving from the prestige discourse of mythology to that of science, pro-gay advocates have retold the Symposium story in the medical context. Although they take place in a different genre, these studies-like Nussbaum's use of Aristophanes-show that gays are more like transsexuals than transvestites, and that the life project of the homosexual is not one of play but of moral seriousness. ${ }^{356}$

This discussion shows that both pro-gay immutability theory and antigay implantation theory support the idea that mutability rather than immutability causes empathy failure in the context of gays. The case of gays thus inverts the logic of Ely's rule. Just as Ackerman showed that "discreteness" and "msularity" could be poor proxies for a group's political powerlessness, ${ }^{357}$ this analysis shows that "immutability" can be a poor proxy for a group's potential to suffer empathy failure. Just as he made the argument that "anonym[ity]" and "diffuse[ness]" could occasion more political powerlessness than "discreteness" and "insularity,"358 this analysis shows that "mutability" can occasion more empathy failure that "immutability."

This illuminates an important difference between this prong and the other two prongs. Courts should deepen their inquiries into the history of discrimination prong and the political powerlessness prong, but need not question the legitimacy of these prongs. In contrast, courts should reject the immutability prong as illegitimate because it is based on the incorrect assumption that immutability is necessarily linked to empathy failure.

\section{ConCLUSION}

I began this Article with an anecdote about a judge who asked me what the pink triangle was. There are many reasons why the encounter remains vivid. First, I was struck that those who are empowered to regulate an identity are not necessarily those who know even its fundamental characteristics. Second, I was shocked by my own deference, my own insistence on interpreting all ambiguity in favor of the judge. These reactions, I think, are the occasion for much of the anger and sadness I feel

356. See supra notes $345-351$ and accompanying text. To claim that pro-gay deployment of immutability results in empathy gains is not to express agreement with the claim that homosexuality is immutable. I remain agnostic on that issue.

357. See Ackerman, supra note 40, at 723-24.

358. Id. 
when I revisit that interchange. Yet I think that there must be another reason why that interchange remains unforgettable. Ultimately, what stays with me about my conversation with the judge is his ability to admit his ignorance. When I mentioned the pink triangle to him, he asked what it was. When I told him, he said he had not known what I told him. Granted, this interchange could have been a willful assertion of his privilege of unknowing, or an unconscious assertion of his insensitivity to the fact that he should have known the meaning of the symbol. But it did not feel like that. The blankness of his face when he said "I didn't know that" seemed like a blankness on which someone might write something.

The double meaning of my title should by now be apparent. First, I have argued that symbols give a thicker response to the doctrinal inquiry relating to suspect scrutiny than more traditional modes of analysis. Second, I have recognized that the use of these symbols in legal discussion is itself suspect. I have thus joined a marginalized group (gays) and a marginalized discourse (literature) to challenge an existing normative framework that has traditionally misunderstood both.

I hope the alliance proves fruitful. Courts, including the Supreme Court, will consider the question of whether gays deserve heightened scrutiny under the Equal Protection Clause in the near future. When they do, I hope they ask the question, "What might it be like to be gay?" I am convinced that this is the question that underlies the spirit of the Equal Protection Clause, a spirit of attempting to inhabit the worlds of distant others. It was the question I heard the judge asking, and I hope the courts ask it with the same openness and desire to know- "What is the pink triangle?" They will ask again and we will answer. 